SAND92-1241

Distribution

Unlimited Release

Category UC-523

Printed September 1992

\title{
RESULTS OF AN EXPERIMENT IN A ZION-LIKE GEOMETRY TO INVESTIGATE THE EFFECT OF WATER ON THE CONTAINMENT BASEMENT FLOOR ON DIRECT CONTAINMENT HEATING (DCH) IN THE SURTSEY TEST FACILITY: THE IET-4 TEST
}

\author{
Michael D. Allen \\ Thomas K. Blanchat \\ Martin Pilch \\ Robert T. Nichols* \\ Severe Accident Phenomenology \\ Sandia National Laboratories \\ Albuquerque, NM
}

SAND--92-1241

DE93 002514

\begin{abstract}
The fourth experiment of the Integral Effects Test (IET-4) series was conducted to investigate the effects of high pressure melt ejection on direct containment heating. Scale models (1:10) of the Zion reactor pressure vessel (RPV), cavity, instrument tunnel, and subcompartment structures were constructed in the Surtsey Test Facility at Sandia National Laboratories. The RPV was modeled with a melt generator that consisted of a steel pressure barrier, a cast $\mathrm{MgO}$ crucible, and a thin steel inner liner. The melt generator/crucible had a hemispherical bottom. head containing a graphite limitor plate with a $3.5-\mathrm{cm}$ exit hole to simulate the ablated hole in the RPV bottom head that would te formed by tube ejection in a severe nuclear power plant accident. The reactor cavity model contained $3.48 \mathrm{~kg}$ of water with a depth of $0.9 \mathrm{~cm}$ that corresponded to condessate levels in the Zion plant. A 43-kg initial charge of iron oxide/aluminum/chromium thermite was used to simulate corium debris on the bottom head of the RPV. Molten thermite was ejected into the scaled reactor cavity by $6.7 \mathrm{MPa}$ steam.

IET-4 replicated the third experiment in the IET series (IET-3), except the Surtsey vessel contained slightly more pre-existing oxygen $(9.6 \mathrm{~mol} . \%$ vs. $9.0 \mathrm{~mol} . \%)$, and water was placed on the basement floor inside the crane wall. The cavity pressure measurements showed that a small steam explosion occurred in the cavity at about the same time as the steam explosion in IET-1. The oxygen in the Surtsey vessel in IET-4 resulted in a vigorous hydrogen burn, which caused a significant increase in the peak pressure, $262 \mathrm{kPa}$ compared to $98 \mathrm{kPa}$ in the IET-1 test. IET-3, with similar pre-existing cxygen concentrations, also had a large peak pressure of $246 \mathrm{kPa}$. The total debris mass ejected into the Surtsey vessel in IET-4 was 40.72 $\mathrm{kg}$, and gas grab sample analysis indicated that $297 \mathrm{~g} \cdot$ moles of hydrogen were produced by steam/metal reactions. About $236 \mathrm{~g} \cdot \mathrm{moles}$ of hydrogen burned and $61 \mathrm{~g} \cdot \mathrm{moles}$ remained unreacted.
\end{abstract}

*Ktech Corp., 901 Pennsylvania NE, Albuquerque, NM 87110 


\section{CONTENTS}

$\underline{\text { Section }}$

Page

1. INTRODUCTION $\ldots \ldots \ldots \ldots \ldots \ldots \ldots \ldots \ldots \ldots \ldots \ldots \ldots \ldots$

2. EXPERIMENT DESCRIPTION $\ldots \ldots \ldots \ldots \ldots \ldots \ldots \ldots \ldots \ldots \ldots$

2.1 Initial Conditions $\ldots \ldots \ldots \ldots \ldots \ldots \ldots \ldots \ldots \ldots \ldots \ldots \ldots$

2.2 Measurements and Instrumentation $\ldots \ldots \ldots \ldots \ldots \ldots \ldots \ldots \ldots$

2.2.1 Pressure Measurements . . . . . . . . . . . . . . . 3

2.2.2 Temperature Measurements .................. 4

2.2 .3 Gas Composition . . . . . . . . . . . . . . . . . . 5

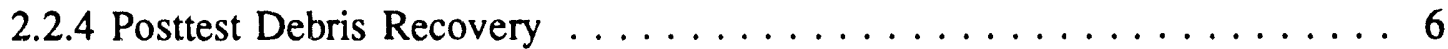

2.2 .5 Debris Velocity ....................... 6

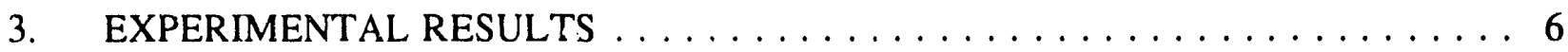

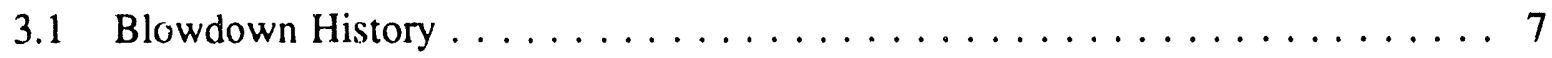

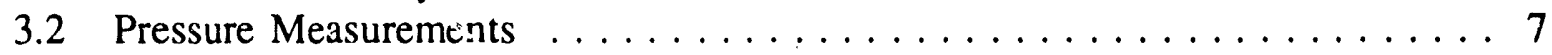

3.2.1 Surtsey Vessel Pressure $\ldots \ldots \ldots \ldots \ldots \ldots \ldots \ldots \ldots \ldots$

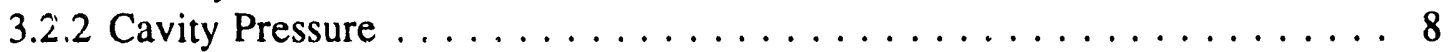

3.2.3 Pressure Measured Inside the Seal Table Koom . . . . . . . . . . . 9

3.2.4 Pressure Measured Inside the Subcompartment Structures . . . . . . . . 10

3.3 Gas Temperature Measurements $\ldots \ldots \ldots \ldots \ldots \ldots \ldots$

3.4 Debris Temperature Measurements . . . . . . . . . . . . . . . . 11

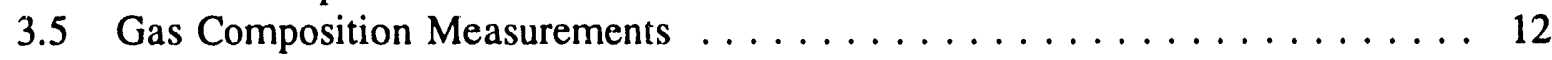

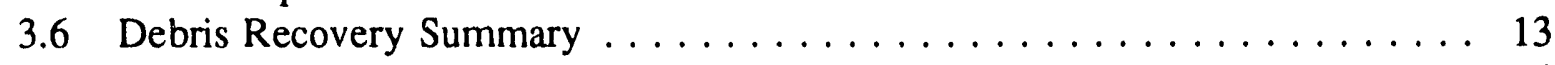

3.7 Energy Balance . . . . . . . . . . . . . . . . . . . . 14

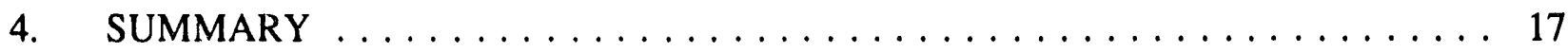

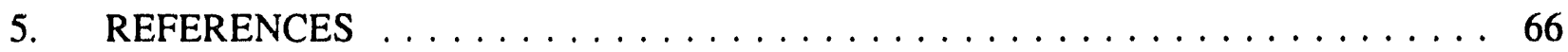




\section{LIST OF TABLES}

Table

Page

1. Instruments $u$ sed in the IET-4 Experiment $\ldots \ldots \ldots \ldots \ldots \ldots$

2. Initial Conditions for the IET-1, IET-3, and IET-4 Experiments . . . . . . . . 26

3. Gas Concentrations Measured in the IET-4 Experiment . . . . . . . . . . 27

4. Debris Recovery Summary for the IET-1, IET-3, and IET-4 Experiments . . . . . . 28

5. Energy Balance for the IET-1, IET-3, and IET-4 Experiments . . . . . . . . . . . 29

6. Summary of the Results of the IET-1, IET-3, and IET-4 Experiments . . . . . . . 29 


\section{LIST OF FIGURES}

$\underline{\text { Figure }}$

$\underline{\text { Page }}$

1. Surtsey vessel, high-pressure melt ejection system, and subcompartment structures used in the IET-4 experiment $\ldots \ldots \ldots \ldots \ldots$

2. Melt generator and $\mathrm{MgO}$ crucible used in the IET -4 experiment $\ldots \ldots \ldots \ldots \ldots$

3. Schematic of the $1: 10$ linear scale model of the Zion reactor cavity . . . . . . 32

4. High-pressure steam boiler, steam accumulator, melt generator, cavity,

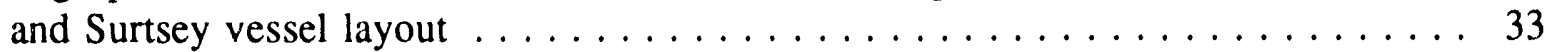

5. Two-dimensional view of the subcompartment structures inside the

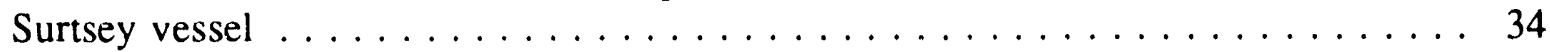

6. Isometric view of the subcompartment structures inside the

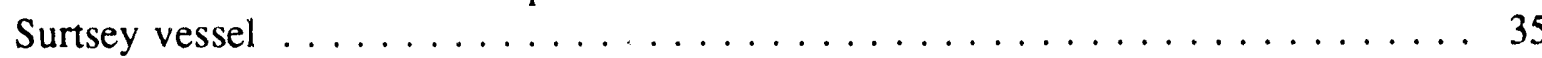

7. Top view of structures inside the Surtsey vessel $\ldots \ldots \ldots \ldots \ldots$

8. Top view of the Surtsey vessel showing instrumentation ports $\ldots \ldots \ldots$. . . . 37

9. Location of Surtsey vessel bulk gas temperature thermocouple arrays $\ldots \ldots \ldots$. . . 38

10. Gas grab sample bottle fill times $\ldots \ldots \ldots \ldots \ldots \ldots \ldots \ldots$

11. Blowdown pressure history for the IET -4 experiment $\ldots \ldots \ldots \ldots \ldots$

12. Steam blowdown temperatures measured in the steam accumulator tank with type-K thermocouples in the IET-4 experiment $\ldots \ldots \ldots \ldots \ldots \ldots \ldots$

13. Surtsey vessel pressure versus time measured at level 1 in the

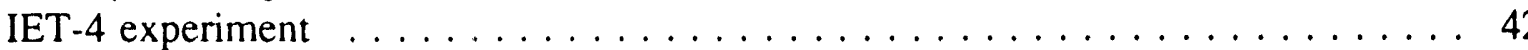

14. Surtsey vessel pressure versus time measured at level 3 in the IET-4 experiment

15. Surtsey vessel pressure versus time measured at level 5 in the IET-4 experiment

16. Surtsey vessel pressure comparisons versus time for the IET-1, IET-3, and IET-4 experiments

17. Cavity pressure and Surtsey vessel pressure versus time in the IET -4 experiment 


\section{List of Figures (continued)}

Figure

$\underline{\text { Page }}$

18. Comparison of the cavity pressures versus time for the IET-1, IET-3, and IET-4 experiments . . . . . . . . . . . . . . . . 47

19. Seal table room absolute pressure and differential pressure compared to Surtsey vessel pressure in the IET-4 experiment $\ldots \ldots \ldots \ldots \ldots \ldots \ldots$

20. Seal table room and Surtsey vessel pressure versus time in the IET-4 experiment . . 49

21. Debris ejection timing into the seal table room in the

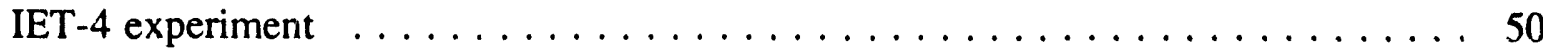

22. Subcompartment absolute pressure and differential pressure compared to Surtsey vessel pressure in the IET-4 experiment $\ldots \ldots \ldots \ldots \ldots \ldots \ldots \ldots$

23. Cavity floor, chute exit, and seal table room temperatures measured with type-K thermocouples in the IET-4 experiment

24. Gas temperatures measured at levels 1,3 , and 5 in the Surtsey vessel with aspirated thermocouples in the IET-4 experiment

25. Gas temperatures inside the subcompartment structures measured with aspirated thermocouples in the IET-1, IET-3, and IET-4 experiments $\ldots \ldots \ldots \ldots \ldots$

26. Gas temperatures inside the seal table room measured with type-K aspirated thermocouples in the IET -3 and IET-4 experiments $\ldots \ldots \ldots \ldots \ldots \ldots$

27. Comparison of the temperatures in the triangular vent space above RCPs $1 \mathrm{~A}$ and $1 \mathrm{D}$ in the IET -3 and IET-4 experiments $\ldots \ldots \ldots \ldots \ldots$

28. Temperature history of the east thermocouple array in the IET-4 experiment $\ldots \ldots$. . 57

29. Temperature history of the west thermocouple array in the IET-4 experiment . . . . 58

30. Relative pressure and bulk gas temperature increase in the Surtsey vessel in the IET-4 experiment

31. Raw pyrometer output at the chute exit measured with a type $11 \times 20$ optical pyrometer in the IET-4 experimen

32. Raw pyrometer output at the chute exit measured with a type $11 \times 30$ optical pyrometer in the IET-4 experiment 


\section{LIST OF FIGURES (concluded)}

$\underline{\text { Figure }}$

Page

33. Debris temperature at the chute exit measured with a type $11 \times 20$ optical

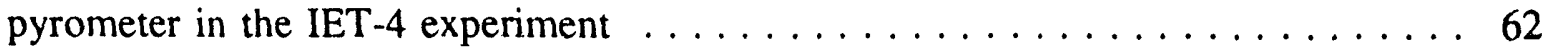

34. Debris temperature at the chute exit measured with a type $11 \times 30$ optical pyrometer in the IET-4 experiment $\ldots \ldots \ldots \ldots \ldots \ldots \ldots \ldots \ldots \ldots$

35. Debris temperature measured with the graphite disk calorimeters

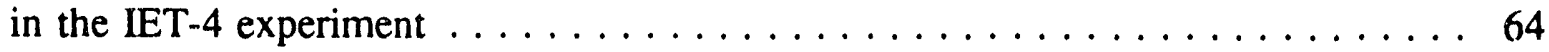

36. Posttest sieve analysis of debris recovered from outside the subcompartment structures in the Surtsey vessel in the IET-4 experiment $\ldots \ldots \ldots \ldots \ldots \ldots 65$ 


\section{ACKNOWLEDGMENTS}

The authors express their gratitude to Michael Oliver, who was the electronics and instrumentation engineer for these experiments, and to James Ross, Tim Covert, and Robert Carolan, who were the mechanical technicians. The authors appreciate the technical review of this report provided by T. Y. Chu and Lubomyra N. Kmetyk. Editorial review was provided by Patty G. Guyer.

This work was funded by the Accident Evaluation Branch of the United States Nuclear Regulatory Commission. 


\subsection{INTRODUCTION}

The Surtsey Test Facility at Sandia National Laboratories (SNL) is used to perform scaled experiments for the Nuclear Regulatory Commission (NRC) that simulate hypothetical high-pressure melt ejection (HPME) accidents in a nuclear power plant (NPP). These experiments are designed to investigate the phenomena associated with direct containment heating $(\mathrm{DCH})$. High-temperature, chemically reactive melt is ejected by high-pressure steam into a 1:10 linear scale model of a reactor cavity. Debris is entrained by the steam blowdown into the Surtsey vessel, where specific phenomena, such as the effect of subcompartment structures, water in the cavity, and hydrogen generation and combustion, can be studied.

The fourth Integral Effects Test (IET-4) using a small scale model of the Zion Nuclear Generating Station was successfully conducted on March 20, 1992. The purpose of this test was to replicate the IET-3 test [Allen et al. 1992c], which was conducted with $0.09 \mathrm{MPa}$ of air and $0.1 \mathrm{MPa}$ of nitrogen in the Surtsey vessel, along with $3.48 \mathrm{~kg}$ of water in the scaled reactor cavity model. In addition, the IET-4 test was conducted with $71 \mathrm{~kg}$ of water on the basement floor inside the crane wall. The water on the floor of the cavity and containment basement were scaled to condensate levels in a NPP accident. Molten debris deflected back to the containment basement floor should be quenched by this water, but the interaction could produce additional hydrogen. The comparison between the IET-3 and IET-4 tests should provide a measure of the change in peak Surtsey vessel pressure due to debris quenching and combustion of additional hydrogen.

The Surtsey IET test series in the Zion configuration is being conducted at 1:10 linear scale, and Argonne National Laboratory (ANL) counterpart tests are being performed at 1:40 scale. Results of these experiments will allow assessment of scaling methodologies proposed by the Severe Accident Scaling Methodology - Technical Program Group (SASM-TPG) ${ }^{1}$ and by SNL. ${ }^{2}$

\subsection{EXPERIMENT DESCRIPTION}

All tables and figures are located at the end of the text. Table 1 is a listing of the instrumentation used in the IET-4 experiment, including the channel number, type, purpose, and location of each instrument. The circled numbers in Figures 1 through 9 correspond to the channel numbers in the data acquisition system listed in Table 1.

${ }^{1}$ SASM - TPG, Nov. 1991, An Integrated Structure and Scaling Methodology for Severe Accident Technical Issue Resolution, NUREG/CR-5809, EG\&G-2659, draft for comment, Idaho National Engineering Laboratory, Idaho Falls, ID.

${ }^{2}$ M. Pilch and M. D. Allen, A Scaling Methodology for Direct Containment Heating with Application to the Design and Specification of an Experiment Program for Resolving DCH Issues, SAND91-2784, to be published, Sandia National Laboratories, Albuquerque, NM. 
Figure 1 is a composite view of the Surtsey vessel, the HPME delivery system, and the outer boundary of the subcompartment structures used in the IET-4 experiment. This figure shows the instrument penetration ports at six levels in the Surtsey vessel.

In the Surtsey IET tests, 1:10 linear scale models of the Zion reactor pressure vessel (RPV), cavity, in-core instrument tunnel, and subcompartment structures were used. The RPV was modeled with a melt generator that consisted of a steel pressure barrier, a cast $\mathrm{MgO}$ crucible, and a thin steel inner liner (Figure 2). The melt generator/crucible had a hemispherical bottom head containing a graphite limitor plate with a $3.5 \mathrm{~cm}$ exit hole to simulate the ablated hole in the RPV bottom head that would be formed by tube ejection and hole ablation in a NPP severe accident.

The cavity used in the IET-4 test (Figure 3) was a 1:10 linear scale model of the Zion reactor cavity that was designed to withstand internal pressures of $6.9 \mathrm{MPa}$ with a safety factor of 4 . The inclined portion of the instrument tunnel entered the bottom head of Surtsey at a $26^{\circ}$ angle from vertical, as it does in Zion. A false concrete floor was constructed in the Surtsey vessel, similar to the floor of the Zion basement, so that the inclined portion of the instrument tunnel was about 2.7 times the correct scaled length of the inclined part of the Zion instrument tunnel. This floor was constructed in Surtsey to match the configuration of the ANL facility. Figure 4 shows the experiment configuration, with the layout of the high pressure steam boiler, accumulator, burst diaphragm, melt generator, and cavity connection to the Surtsey vessel.

The subcompartment structures included 1:10 linear scale models of the crane wall, four steam generators (SG), four reactor coolant pumps (RCP), the opening in the floor of the seal table room for the instrument guide tubes, the seal table room, the biological shield wall, the refueling canal, the radial beams and the gratings at the RCP deck, and the operating deck (Figures 5, 6, and 7). The steam generators, RCPs, and gratings were made of steel and the other structures were constructed of reinforced concrete. All of the structures were painted with an epoxy-base paint. Figure 8 gives the top view of the Surtsey vessel, showing the orientation and location of the instrument penetrations through the vessel ports at six different levels.

The steam accumulator tank was pressurized to $\approx 6.3 \mathrm{MPa}$ with superheated steam. After the pressurization sequence, the iron oxide/aluminum/chromium thermite mixture was ignited remotely with a braided wire fuse placed on top of the compacted thermite. After the thermite was ignited, the pressure in the crucible rapidly increased. This pressure increase verified that the thermite reaction had started, and signaled the operator to fail the burst diaphragm separating the steam accumulator tank and the molten thermite in the melt generator. This brought superheated steam into contact with the molten thermite. Upon contacting and failing a fusible brass plug at the bottom of the crucible, the molten thermite in the crucible was expelled by high-pressure steam into the cavity.

Zero time for HPME was set by the data acquisition system as the time at which the melt failed the brass plug and entered the cavity. This event was signaled by a photodiode located at the melt plug exit. When the hot melt burst through the brass plug, the intense light emitted from the melt caused the photodiode to emit a signal that was used to mark the initiation of the HPME. 


\subsection{Initial Conditions}

The IET-4 test was conducted with the following initial conditions: (1) the melt simulant was $43 \mathrm{~kg}$ of iron oxide/aluminum/chromium powder; (2) the driving gas was $\approx 583 \mathrm{~g} \cdot \mathrm{moles}$ of superheated steam $(\approx 555 \mathrm{~K})$ at an initial absolute pressure of $6.7 \mathrm{MPa}$; (3) the initial absolute pressure in the Surtsey vessel was $\approx 0.2 \mathrm{MPa}$ of air diluted with nitrogen $\left(9.59 \mathrm{~mol} . \% \mathrm{O}_{2}\right) ;$ (4) the cavity was filled with $3.48 \mathrm{~kg}$ of water $(335 \mathrm{~K})$ that was $0.9 \mathrm{~cm}$ deep; and (5) the containment basement floor inside the crane wall (floor area $=4.6 \mathrm{~m}^{2}$ ) was filled with $\approx 71 \mathrm{~kg}$ of water $(286 \mathrm{~K})$ that was $1.5 \mathrm{~cm}$ deep. Table 2 lists the initial conditions of the IET-4 experiment, along with IET-1 and IET-3 initial conditions for comparison.

\subsection{Measurements and Instrumentation}

The most significant variables to measure in the Integral Effects Tests (IETs) are: (1) the increase in pressure and temperature in the Surtsey vessel, (2) the cavity pressure, (3) the number of moles of hydrogen generated by the reaction of metallic debris with steam driving gas, and with water in the cavity and on the containment basement floor, (4) the debris temperature as it exited the instrument tunnel, (5) the debris temperature as it struck the concrete structure, (6) the debris interaction times, (7) the debris particle size, (8) and the mass of debris recovered from specific locations in the Surtsey vessel. The instrumentation and techniques used to make these measurements are described in the sections below.

\subsubsection{Pressure Measurements}

Six pressure transducers with a range of $0-0.69 \mathrm{MPa}$, two at each level 1,3 , and 5 (Channels 21 through 26 in Figures 1 and 8), were used to measure the pressure in the upper dome of the Surtsey vessel in the IET-4 experiment. These transducers were mounted in tapped holes in instrument penetration ports in the sides of the Surtsey vessel and had their sensing ends protected with steel turnings. Pressure transducers with a range of 0-6.9 $\mathrm{MPa}$ were used to measure the gas pressure in the accumulator tank (Channel 32 in Figure 4), in the crucible above the thermite (Channels 34 and 35 in Figures 2, 3, and 4), and in the scaled reactor cavity (Channel 36 in Figures 3 and 4). Pressure transducers with a range of $0-0.69 \mathrm{MPa}$ were used to measure the gas pressure in the subcompartment structures and in the seal table room (Channels 39 and 40 in Figures 5, 6, and 7). These transducers were metal diaphragm strain gau!ge-type pressure transducers (Model 141-1, Precise Sensor, Inc., Monrovia, CA). In addition, two pressure transducers were embedded in the concrete walls of the round section of the cavity under the melt generator (labeled P1 and P2 in Figures 3 and 4), and were piezoelectric-type gauges with a range of 0-6.9 $\mathrm{MPa}$. The specified accuracy from the manufacturer for the pressure transducers is less than \pm 0.50 percent at full-scale output. These instruments are routinely recalibrated at SNL against the National Bureau of Standards, and accuracies are always within manufacturer's specifications. The frequency response is $22 \mathrm{kHz}(16 \mu$ s rise time) for the $0-0.69 \mathrm{MPa}$ range pressure transducers, and is $36 \mathrm{kHz}(10 \mu \mathrm{s}$ rise time) for the 0-6.9 $\mathrm{MPa}$ range pressure transducers. The data acquisition system recorded data from the pressure transducers at a rate of 1400 data points per second from thermite ignition to about 60 seconds following the HPME transient. 


\subsubsection{Temperature Measurements}

Following the HPME transient, the gas temperatures in the Surtsey vessel were measured with five aspirated thermocouple assemblies. An aspirated thermocouple assembly consisted of three bare, type- $\mathrm{K}$ thermocouples $(0.127 \mathrm{~mm}$ wire) mounted in an anodized aluminum tube. Each tube was opened with a solenoid-operated valve that was actuated remotely by a signal from the photodiode under the melt plug immediately after the HPME transient. One of these assemblies was installed through instrumentation ports at each level 1, 3, and 5 (Channels 41 through 49 in Figures 1 and 8). A thermocouple assembly was also installed through the refueling canal wall just above the radial concrete beam on the same side as the instrument tunnel exit. This thermocouple assembly was used to measure gas temperature inside the subcompartment structures (Channels 51, 52, and 53 shown in Figures 5, 6, and 7). Another thermocouple assembly was installed through the crane wall into the seal table room (Channels 54, 55, and 56 in Figures 5, 6, and 7). Calculations by SNL have shown that the worst-case temperature underprediction by the thermocouple assemblies would be 13 percent at the beginning of the HPME event (when the gas temperatures are low) to 6 percent at equilibrium (when the gas temperatures have peaked). ${ }^{3}$

Two type-K thermocouple arrays (Channels 68 through 77 in Figures 6, 7, and 9) were installed in the Surtsey vessel to measure bulk gas temperature above the operating deck. Each array consisted of five approximately equally spaced thermocouples suspended near the northeast vent (above the $1 \mathrm{C} \mathrm{RCP}$ ) and above the west end of the refueling canal. Note that the vessel wall near the chute exit has been referenced as the north wall. Figure 9 gives the spacing and relative position of the thermocouple arrays. All type- $K$ thermocouples are made of $0.254 \mathrm{~mm}$ wire with a $1.5875 \mathrm{~mm}$ sheath. The temperature range is $273-1523 \mathrm{~K}$. The maximum limit of error using the manufacturer's calibration is $\pm 9.4 \mathrm{~K}$ at $1523 \mathrm{~K}$, with a 0.3 $s$ time constant. The thermocouples had the sheath removed at the tip, exposing the junction to ensure a fast time response. The thermocouples were located $\approx 71 \mathrm{~cm}$ from the Surtsey vessel wall.

Two type-K thernıcouples (Channeis 66 and 67 in Figures 6 and 7) were installed inside the triangular vent space above the $1 \mathrm{~A}$ and 1D RCPs. These thermocouples measured the temperature of the gas as it exited the subcompartment structures.

The temperature of the driving gas in the steam accumulator tank was measured using two type-K thermocouples (Channels 91 and 92 in Figure 4) that extended through the accumulator shell and were secured in place using pressure-tight fittings. Measurements from these thermocouples were important because the measured temperature and pressure in the accumliator tank were used to calculate the number of moles of steam driving gas.

Two pyrometers (Channels 37 and 38 in Figures 5, 6, and 7) were used to measure the temperature of the debris as it exited from the instrument tunnel exit. An optical pyrometer (rype $11 \times 20$, Ircon Inc., Niles, IL) was located inside the biological shield wall and was focused just above the instrument tunnel exit through a fused silica window sealed in the

${ }^{3}$ Thomas Blanchat, May 1992, "Aspirated Thermocouple Calculations," Letter Report to the U.S. Nuclear Regulatory Commission, Sandia National Laboratories, Albuquerque, NM. 
biological shield wall. Another optical pyrometer (type $11 \times 30$, Ircon Inc., Niles, IL) was located outside the crane wall and was focused just above the instrument tunnel exit through a fused silica window sealed in the crane wall. A debris emissivity of 0.9 was assumed when converting the results (in $\mathrm{mV}$ ) from the optical pyrometers to temperature (in $\mathrm{K}$ ). A debris emissivity near the blackbody value was assumed because the debris appeared black when inspected posttest. The calculated debris temperature is not very sensitive to the assumed debris emissivity. For example, at approximately $2000 \mathrm{~K}$ a 13 percent change in the assumed emissivity resulted in only a 1.9 percent change in the calculated debris temporature.

The optical pyrometers had a response time of $1.5 \mathrm{~ms}$ to 95 percent of their full range. A new, low-range, controller was installed on both pyrometers for the IET-4 test. This controller was capable of measuring temperatures between $1323 \mathrm{~K}$ and $1773 \mathrm{~K}$ with a specified accuracy of 1 percent of the full-scale temperature. In a transient event such as a HPME experiment, the accuracy of the pyrometer measurements was expected to be no better than $\pm 25 \mathrm{~K}$. The pyrometers were factory calibrated and the type $11 \times 30$ pyrometer is routinely recalibrated by the Sandia Radiant Heat Facility. (Note that since the type $11 \times 20$ optical pyrometer is sealed inside the biological shield wall, it cannot be recalibrated.)

A thin-foil graphite calorimeter (Channel 1 in Figures 5 and 6) was embedded in the crane wall directly in the flight path of the debris to measure the debris contact temperature as it impacted the structure. Another thin-foil graphite calorimeter (Channel 4 in figures 5 and 6) was embedded in the seal table room floor, facing the chute exit. Two other thin-foil graphite calorimeters (Channels 2 and 3 in Figures 5 and 6) were embedded in the containment basement floor between the chute exit and the biological shield wall. Each graphite calorimeter consisted of a $1-\mathrm{mm}$ thick graphite disk with a diameter of $25.4 \mathrm{~mm}$. Each graphite disk had a type-S thermocouple attached to the backside of the disk and was set in a ceramic holder that was embedded in the concrete structure. The response time of these graphite calorimeters was on the order of $10 \mathrm{~ms}$.

Data points from the thermocouples and the pyrometers were recorded by the data acquisition system at a rate of 10 per second prior to thermite ignition. Then, just prior to thermite ignition, the data acquisition system was switched to the fast data acquisition mode, in which data points were recorded at a rate of 1400 per second.

\subsubsection{Gas Composition}

Twelve pre-evacuated $500-\mathrm{cm}^{3}$ gas grab sample bottles were used to collect samples from the vessel (Labeled L2, L4, L6, and B in Figures 1, 5, 6, 7 and 8) at the following locations and times: three background samples at levels 2,4 , and 6 were obtained by opening solenoid valves remotely for $10 \mathrm{~s}$ just prior to ignition of the thermite; three gas grab sample bottles located at levels 2, 4, and 6 were opened remotely for 10 seconds at 2 minutes after the HPME; three gas grab sample bottles at levels 2, 4, and 6 were opened manually for 10 seconds at $\approx 30$ minutes after the HPME; two gas grab sample bottles inside the subcompartment structures were opened $2 \mathrm{~s}$ after the HPME and remained open for $5 \mathrm{~s}$; and one gas grab sample bottle that had its inlet inside the subcompartment structure was opened 2 minutes after the HPME for $10 \mathrm{~s}$. In addition, two gas grab samples were taken from the cavity following the HPME; one was opened as the HPME was initiated and remained open 
for $2 \mathrm{~s}$, and the other was opened at $0.5 \mathrm{~s}$ following the HPME and remained open for $2 \mathrm{~s}$ (Labeled $\mathrm{C}$ in Figure 3). The gas samples were analyzed using gas mass spectroscopy by Battelle Pacific Northwest Laboratories in Richland, WA.

Tests were performed to measure the fill times of the $500-\mathrm{cm}^{3}$ gas grab sample bottles at three different initial pressures (atmospheric, $0.26 \mathrm{MPa}$, and $0.43 \mathrm{MPa}$ ). An evacuated bottle was separated from a pressure source by a remotely operated solenoid valve. A pressure transducer was installed downstream of the valve and pressure source, and the fill time was recorded by the data acquisition system. Figure 10 shows the results of these tests. The data indicate that all bottles were filled in less than $2 \mathrm{~s}$, regardiess of the upstream pressure.

\subsubsection{Posttest Debris Recovery}

The total debris mäss dispersed into the Surtsey vessel and the debris mass in specific locations were determined by a very careful posttest debris recovery procedure. The following measurements were made: (1) mass of the molten debris in the cavity and inclined portion of the instrument tunnel; (2) mass on the horizontal surfaces outside the subcompartment structures; (3) mass on the vertical surfaces outside the subcompartment structures; (4) mass recovered from the floor inside the structures; (5) mass recovered from the horizontal surfaces other than the floor inside the structures; (6) mass recovered from the vertical surfaces inside the structures; (7) mass recovered from the doorways inside the structures; (8) mass recovered from the seal table room; (9) mass recovered from the rooms adjacent to the seal table room; and (10) mass recovered from the melt generator/crucible.

\subsubsection{Debris Velocity}

Breakwires were placed across the opening from the containment basement to the seal table room and at the seal table room exit plug (Channels 16 and 17 in Figures 5 and 6). When the debris front severed the breakwire, a timing signal was recorded by the data acquisition system. The breakwire was intended to give timing information on entry of debris into and out of the seal table room.

\subsection{EXPERIMENTAL RESULTS}

The experimental results of the IET-4 test are described in this section. The crane wall suffered significant damage in IET-4 that had not occurred in previous experiments [Allen et al. $1992 \mathrm{c}, \mathrm{d}$ ]. $A \approx 40 \times 80 \mathrm{~cm}$ hole was blown out of the crane wall near the top of the seal table room. The area of the crane wall that formed the outside wall of the seal table room was $63 \mathrm{~cm}^{2}$ and the hole was $21 \mathrm{~cm}^{2}$; thus, $\approx 33 \%$ of the outside wall of the seal table room was blown out. The crane wall was also cracked near the walls of the seal table room about $30 \mathrm{~cm}$ from the top of the operating deck. It is believed that repeated, direct hits of molten debris from previous experiments may have dehydrated and weakened the concrete in this region. The ramification of this anomaly and the effects on the experimental results are still being studied. 


\subsection{Blowdown History}

Figure 11 shows the blowdown pressure history of the IET-4 experiment. In the experiment, the free volume in the crucible and in the $10-\mathrm{cm}$ diameter pipe above the crucible was purged with nitrogen. The accumulator tank (volume $=0.29 \mathrm{~m}^{3}$ ) was pressurized with superheated steam to $\approx 6.3 \mathrm{MPa}$. After the thermite was ignited, the burst diaphragm separating the steam accumulator tank and the molten thermite was failed remotely by the operator; this brought steam into contact with the molten thermite at an experiment time of about $-2 \mathrm{~s}$. The steam driving gas pressure for the IET-4 test was determined from the blowdown pressures shown in Figure 11. The horizontal dotted line across Figure 11 shows that the steam driving gas pressure at the initiation of the HPME was $6.7 \mathrm{MPa}$.

The number of moles of steam driving gas can be calculated using accumulator steam pressure, temperature and volume. In IET-4, the number of moles of steam driving gas was calculated at two times: before burst diaphragm failure $(t=-5 \mathrm{~s})$ and at HPME initiation $(t=$ $0 \mathrm{~s})$. At $\mathrm{t}=-5 \mathrm{~s}$, the steam pressure was $6.35 \mathrm{MPa}$, the steam temperature was $580 \mathrm{~K}$, and the volume of the accumulator tank was $0.29 \mathrm{~m}^{3}$. The steam driving gas was calculated to be $489 \mathrm{~g}$.moles. At $\mathrm{t}=0$, the steam pressure was $6.7 \mathrm{MPa}$, the steam temperature ": $0555 \mathrm{~K}$, and the volume of the accumulator tank plus the piping and void in the crucible $v$ is 0.308 $\mathrm{m}^{3}$. The steam driving gas was calculated to be $582 \mathrm{~g} \cdot$ moles. A small amount of water inside the piping or burst diaphragms must have been introduced at burst diaphragm failure, which vaporized upon contact with the molten thermite. This resulted in a small pressure increase in the accumulator/crucible, shown in Figure 11 at $t=-1.5 \mathrm{~s}$.

Figure 11 shows that steam blowdown from the accumulator tank was complete at $\approx 4 \mathrm{~s}$. The IET -3 experiment had a similar steam blowdown curve. Figure 12 gives the steam temperature history in the accumulator during the blowdown.

In the IET tests, it is more difficult to distinguish single-phase thermite ejection and steam blowthrough from the changes in shape and inflection points in the blowdown curve (Figure 11) than in earlier experiments [Allen et al. 1991, 1992a, 1992b]. The IET tests used a melt generator that was a 1:10 linear scale model of the hemispherical bottom head of a RPV. This geometry produced a more rounded shape in the early portion of the steam blowdown curve compared to the previous tests, which used a relatively long, narrow cylinder as the melt generator. Steam blowthrough occurred earlier in the IET experiments than in previous tests due to the new melt generator design.

\subsection{Pressure Measurements}

Pressure transducers were used to measure the pressure increase due to the HPME transient in the Surtsey vessel, in the cavity, in the seal table room, and in the subcompartment structures. The following sections describe the results of the pressure measurements. 


\subsubsection{Surtsey Vessel Pi assure}

Figures 13,14 , and 15 show the absolute pressure in the Surtsey vessel versus time measured at levels 1,3 , and 5, respectively. These figures have a horizontal dotted line across the graph at the initial pressure in Surtsey prior to the HPME transient. The initial absolute pressure was $\approx 0.20 \mathrm{MPa}$ as listed in the table of initial conditions (Table 2). These figures also have a horizontal dotted line across the graph at the peak pressure caused by the HPME. These figures show that the pr'sssures measured at levels 1, 3, and 5 in the Surtsey vessel with three different pressure transducers were virtually identical. The pressure increase in the IET-4 experiment was $0.262 \mathrm{MPa}$, and the peak pressure was reached at $\approx 2.5 \mathrm{~s}$ after the beginning of the HPME transient.

Figure 16 compares the Surtsey vessel pressure measured in IET-4 to the presiure measured in IET-1 and IET-3 from 0 to $60 \mathrm{~s}$. The peak pressure increase was $0.098 \mathrm{MPa}$ in IET-1, $0.246 \mathrm{MPa}$ in IET-3, and $0.262 \mathrm{MPa}$ in IET-4; and the general shape of the pressurization curves were similar. The peak pressure was reached at $\approx 2.5 \mathrm{~s}$ in all tests, but the pressure decreased more rapidly after $2.5 \mathrm{~s}$ in IET-3 and IET-4. This may be due to thr fact that the hydrogen burn was complete after a few seconds. Figure 16 dramatically shows the effect of the hydrogen burn on the vessel pressure in IET-3 and IET-4.

\subsubsection{Cavity Pressure}

The timing of debris ejection from the cavity into the subcompartment structures is important when analyzing a HPME/DCH event. The timing of debris ejection is best understood by comparing the cavity pressure to the Surtsey vessel pressure. Figure 17 shows the cavity pressure and Surtsey vessel pressure versus time for the IET-4 experiment. This figure shows a relatively small peak in the cavity pressure just after the HPME began. This peak was due to gas expansion caused by hot thermite entering the cavity. The large second peak, which started at $\approx 0.05 \mathrm{~s}$ and had an absolute pressure of $\approx 0.95 \mathrm{MPa}$, had a shock wave associated with it. This was a small steam explosion, as was observed in IET-1 [Allen et al. 1992d]. There is previous evidence [Allen et al. 1992a] that small steam explosions in the reactor cavity have little effect on the HPME/DCH event. The third broad peak, which occurred between $\approx 0.4$ and $\approx 0.8 \mathrm{~s}$, was due to thermite entrainment from the cavity caused by the steam blowdown; thus the debris entrainment interval lasted $\approx 0.4 \mathrm{~s}$.

In previous Surtsey experiments with a $3.5 \mathrm{~cm}$ exit hole (LFP-1A, LFP-2A, LFP-8A, [Allen et al. 1991] and WC-1 [Allen et al. 1992a]), the debris entrainment interval was $\approx 1 \mathrm{~s}$. In IET-1, IET -3 and IET- 4 the debris entrainment intervai was $\approx 0.45 \mathrm{~s}$. Differences in the debris entrainment interval observed in the IET experiments compared to earlier Surtsey tests are probably due to the new melt generator/crucible design. The present design used a 1:10 linear scaled hemispherical bottom head, whereas the melt generator used in previous experiments had a relatively long, narrow cylindrical shape, and the molten thermite was pushed out with a piston-like motion.

Figure 18 is a plot comparing the cavity pressures measured in the IET-1, IET-3, and the IET-4 experiments. In all experiments, a small initial pressure spike was caused by gas expansion due to hot thermite entering the cavity. The second peak in the IET-1 and the 
IET-4 curves were clearly due to steam explosions. The second peak in the IET-3 curve was due to rapid vaporization of water, and lagged the IET-1 peak because the vaporization process was slower than a steam explosion. The third peak in all tests was the result of debris entrainmen: by the steam blowdown.

High speed photography (16 mm color camera at 1000 frames per second) was employed in the IET-4 test. Plexiglas ports (Figure 8) were installed in the top head of the vessel and at level 3 (lookirig from south to north above the seal table room ceiling plug). The side view camera at Surtsey mid-level provided the best qualitative view of the HPME event. At $\approx 1 \mathrm{~s}$, a bright orange plume of fire could be seen rising up and filling the vessel centerline, indicative of a hydrogen burn. This was quickly followed by molten debris particles. Debris velocity was calculated to be $\approx 14 \mathrm{~m} / \mathrm{s}$ at level 3 , similar to the $16 \mathrm{~m} / \mathrm{s}$ calculated from the breakwire array data obtained in the LFP-8A experiment [Allen et al. 1991].

\subsubsection{Pressure Measured Inside the Seal Table Room}

Figure 19 shows the absolute pressure measured inside the seal table room and the pressure measured in Surtsey plotted against time. The seal table room pressure was negative with respect to the Surtsey vessel pressure between $\approx 0.2 \mathrm{~s}$ and $>5 \mathrm{~s}$. This was confirmed by a negative seal table room differential pressure, also shown in Figure 19. This was different than the seal table room pressure behavior measured in IET-3 [Allen et al. 1992c], where the seal table room pressure was equal to the vessel pressure except during the debris entrainment interval from $\approx 0.4$ to $0.7 \mathrm{~s}$. The large amount of steam produced when the hot thermite hit the water on the containment basement floor effectively cooled the gas within the subcompartment structures. Apparently, hydrogen burned in the upper dome of Surtsey while steaming of water cooled the subcompartment atmosphere, resulting in a negative pressure with respect to the pressure in the Surtsey upper dome.

Figure 20 shows the absolute pressure in the seal table room and Surtsey vessel plotted against an experiment time between 0 and $0.45 \mathrm{~s}$. The first peak in the seal table room pressure was caused by hot thermite entering the cavity. The second larger pressure peak was probably caused by a small steam explosion. The vertical dotted lines in Figure 20 mark the resonance in the Surtsey vessel caused by the steam explosion. The frequency of the resonance was $20 \mathrm{~Hz}$. This phenomenon was also observed in IET-1 [Allen et al. 1992d].

A breakwire was placed across the opening in the seal table room floor to measure the timing of debris ejection into the seal table room. Another breakwire was placed across the operating deck at the opening in the seal table room ceiling. Figure 21 shows the breakwire signals plotted on the same curve with the cavity pressure. Apparently, a steam explosion created a shock wave that caused the breakwires to fail in succession, so no timing information on debris ejection was obtained from these breakwires. The time between failure of the breakwires was $\approx 0.003 \mathrm{~s}$, giving a calculated velocity for the shock wave on the order of $300 \mathrm{~m} / \mathrm{s}$. 


\subsubsection{Pressure Measured Inside the Subcompartment Structures}

Figure 22 shows the absolute pressure measured in the subcompartment structures and in the Surtsey vessel plotted for an experiment time of 0 to $1 \mathrm{~s}$. This figure also shows the differential pressure between the subcompartment structures and the Surtsay vessel upper dome. Figure 22 shows the same phenomenon as in Figure 19, i.e, negative pressure inside the subcompartment structures cs mpared to the vessel pressure. Note that in IET-3 [Allen et al. 1992c], there was never a negative differential pressure between the inside of the subcompartment structures and the upper dome of the Surtsey vessel during the HPME transient.

\subsection{Gas Temperature Measurements}

Figure 23 compares the temperature measurements from the type- $\mathrm{K}$ thermocouples installed on the cavity floor, at the chute exit, and at the seal table room floor opening. At $0.1 \mathrm{~s}$, the melt was on the cavity floor. At $0.2 \mathrm{~s}$, the debris was being ejected through the chute exit. This is verified by the increase in temperature at the seal table room at $0.2 \mathrm{~s}$. Note that all three type- $\mathrm{K}$ thermocouples were over-ranged at $1530 \mathrm{~K}$.

Figure 24 shows the gas temperatures measured at the Surtsey vessel walls with aspirated thermocouples at levels 1, 3, and 5 during the IET-4 experiment. The gas temperatures measured at level 3 in the Surtsey vessel were substantially higher than the temperatures measured at levels 1 and 5 . The higher temperature at level 3 was caused by hydrogen burning as it exited the vent spaces above the RCPs. The peak temperature at level 3 in IET-4 was $1100 \mathrm{~K}$, comparable to $1050 \mathrm{~K}$ temperature in IET-3 [Allen et al. :992c], and both were noticeably higher (and shorter in duration) than the $635 \mathrm{~K}$ temperature ineasured at level 3 during the IET-1 [Allen et al. 1992d] test. A noticeable difference between IET-3 and IET -4 is that temperature at level 1 did not rise. This may be attributed to the steam produced in the subcompartment structures cooling the lower level areas in the vessel, or due to a different flow path for debris/gas due to the crane wall damage.

Since no hydrogen was burned in IET-1 [Allen et al. 1992d], hydrogen combustion clearly caused the greater magnitude and different shape of the IET-3 and IET-4 temperature peak at level 3. The gas temperature at level 5, which is relatively high in the vessel, was barely above the ambient temperature. This is an indication that not much debris was dispersed into the upper dome of the vessel, and that no hydrogen burns occurred at this level. High-speed films of the IET-3 and IET-4 experiments support this explanation.

Figure 25 shows the gas temperature in IET-1, IET-3, and IET-4 experiments measured inside the subcompartment structures with an aspirated thermocouple. This thermocouple was located through the refueling canal wall just above the radial beam at the RCP deck level, and was on the same side of the refueling canal as the instrument tunnel opening into Surtsey (Channels 51, 52, and 53 in figures 5,6, and 7). All three of the type-K thermocouples in the aspirated thermocouple assembly that sampled gas from inside the subcompartment structures showed identical temperature-versus-time curves. The large, broad peak in Figure 25 corresponds to debris entrainment from the cavity. The gas temperature reached a peak of $\approx 1120 \mathrm{~K}$ at $\approx 0.9 \mathrm{~s}$ in IET-4. Although no hydrogen combustion occurred in IET-1, the peak 
gas temperatures in the subcompartment structures in IET-1, IET-3, and IET-4 were almost identical. This indicates that the primary mechanism for heating the subcompartment atmosphere may be debris/gas heat transfer, not hydrogen combustion.

Figure 26 compares IET-3 and IET-4 temperature-versus-time curves for the aspirated thermocouple assembly in the seal table room; the aspirated thermocouple at the same location in IET- 1 was destroyed and no data were obtained. Figure 26 shows a peak temperature of $\approx 1200 \mathrm{~K}$ at $\approx 0.7 \mathrm{~s}$ in IET-4, which corresponds to the end of the debris entrainment interval, at which point the thermocouple was destroyed. The peak temperature probably coincides with the time at which the maximum amount of debris was suspended in the seal table room atmosphere.

Figure 27 shows the measured temperatures in the triangular vent spaces above the $1 \mathrm{~A}$ and 1D RCPs plotted against time for the IET-3 and IET-4 tests. The 1A RCP vent space was diagonally across the operating deck from the $1 D$ vent space (Channels 66 and 67 in Figure 7). The peak temperature in the $1 \mathrm{~A}$ vent space was $925 \mathrm{~K}$ at $\approx 1 \mathrm{~s}$ in IET-4, compared to a peak temperature $1370 \mathrm{~K}$ at $\approx 1 \mathrm{~s}$ in IET-3. The temperature in the $1 \mathrm{D}$ vent space reached a peak of $780 \mathrm{~K}$ at $\approx 1.1 \mathrm{~s}$ in IET-4, compared to a peak temperature $870 \mathrm{~K}$ at $\approx 1 \mathrm{~s}$ in IET-3. The higher temperatures measured in IET-3 and IET-4 compared to those measured in IET-1 [Allen et al. 1992d] indicate that hydrogen burned as it was pushed out of the vent spaces above the RCPs. The difference in peak temperatures in the 1D vent space for IET-3 and IET-4 can probably be attributed to the steam production in the subcompartment structures and/or the new flow path for hot gas through the hole in the crane wall.

Bulk gas temperatures from the east and west thermocouple arrays used in IET-4 are shown in Figures 28 and 29. These thermocouples measured temperature from about level 3 to halfway between level 5 and level 6 . Typically, the bottom thermocouple measured a higher temperature than the top thermocouple. An average bulk temperature is also plotted on Figure 28 and Figure 29. Since it appears that thermocouples 2 and 3 an the west array were destroyed, they were removed from the average at $2.0 \mathrm{~s}$ and $4.74 \mathrm{~s}$, respectively.

Figure 30 plots the relutive magnitude at the east and west average bulk gas temperature increase against the relative magnitude increase in vessel pressure in IET-4. As expected (assuming an ideal gas), the relative magnitude increase $(\approx 2.3)$ in both pressure and temperature are similar.

\subsection{Debris Temperature Measurements}

Two optical pyrometers were used in IET-4 to measure the temperature of the debris as it exited the instrument tunnel chute. Figures 31 and 32 give the raw pyrometer voltage signals for the type $11 \times 20$ and the type $11 \times 30$ pyrometers. Note that voltage signals less than $2 \mathrm{mv}$ are below the temperature calibration range; however, these signals are valuable because they give important information about the timing of debris ejection into the scaled containment basement. Figure 31 indicates that luminous debris passed through the focal point of the type $11 \times 20$ optical pyrometer between $\approx 0.2$ and $\approx 0.9$ seconds. The data from the type $11 \times 30$ pyrometer (Figure 32) indicates that luminous debris entered the containment basement between $\approx 0.4$ and $\approx 0.9$ seconds. 
Figures 33 and 34 give the converted temperature measurements for the pyrometers. Figure 33 shows a peak debris temperature of $1640 \mathrm{~K}$ occurring at $\approx 0.75 \mathrm{~s}$ for the type $11 \times 20$ pyrometer. Figure 34 shows a peak debris temperature of $1560 \mathrm{~K}$ occurring at $\approx 0.70 \mathrm{~s}$ for the type $11 \times 30$ pyrometer. Note that these temperatures were below peak temperatures of 2000 $2300 \mathrm{~K}$ determined during the LFP and WC tests [Allen et al. 1991; Allen et al. 1992a,b]. It is suspected that the lower temperatures determined by the optical pyrometers may be caused by the trapping of aerosols in the subcompartment structures, partially obscuring the optical path between the sensing head and the focal point above the chute exit. The flow area for aerosols out of the subcompartment is 15 percent of the flow area around the structure used in the LFP tests, and the flow path is much more tortuous.

The Surtsey vessel pressure started to increase at $\approx 0.2$ seconds, as soon as the pyrometers indicated that molten debris entered the subcompartment structures. Thus, some molten debris must have entered the subcompartment stuctures at $\approx 0.2$ seconds. From the pyrometer data, debris ejection may have ended at 0.9 seconds, or the pyrometer output may have been completely obscure: by a dense aerosol cloud rebounding off the cold concrete structures in the containment basement. Note that the cavity pressure curve in Figure 17 indicates that debris ejection ended at $\approx 0.8$ seconds.

Figure 35 shows the debris contact temperatures for IET-4 at the surface of the concrete structure measured with four thin-foil graphite calorimeters: one embedded in the crane wall just under the seal table room directly in the path of the debris, one in the ceiling directly over the chute exit, and two in the containment basement floor between the instrument tunnel opening and the biological shield wall. Figure 35 shows that the calorimeter in the crane wall measured a peak debris contact temperature of $\approx 1100 \mathrm{~K}$ at $1.0 \mathrm{~s}$. The calorimeter embedded in the containment basement floor near the instrumenc tunnel exit reached a peak temperature of $400 \mathrm{~K}$ in $\approx 4$ seconds, as did the calorimeter in the containment basement floor near the biological shield wall. Note that these calorimeters are under a hot (possibly boiling) layer of water. A 0.4 MPa saturation temperature reference line is also shown in Figure 35.

\subsection{Gas Composition Measurements}

Fourteen gas grab samples were taken from the Surtsey vessel in the IET-4 experiment. The gas concentrations $\left(\mathrm{N}_{2}, \mathrm{O}_{2}, \mathrm{H}_{2}, \mathrm{CO}\right.$, and $\left.\mathrm{CO}_{2}\right)$ measured in the gas grab samples are listed in Table 3. A $10 \mathrm{~s}$ background sample of the vessel was obtained just prior to ignition. The measured background oxygen concentration was $9.59 \mathrm{~mol} . \%$. The results of the six gas samples taken from levels 2, 4, and 6 in the Surtsey vessel at 2 and 30 minutes after the HPME transient are in excellent agreement. The mean oxygen and hydrogen concentrations \pm standard deviations for these two samples were $7.975 \mathrm{~mol} . \% \mathrm{O}_{2} \pm 0.043$, and $0.827 \mathrm{~mol}_{2} \% \mathrm{H}_{2}$ \pm 0.036 . The total amount of hydrogen generated was $\approx 297 \mathrm{~g} \cdot$ moles in IET-4. The amount of hydrogen generated was determined from the difference between the posttest hydrogen gas grab sample value and the summation of the pre-existing hydrogen gas grab sample value plus the amount of hydrogen burned. Oxygen depletion calculations indicate that $236 \mathrm{~g} \cdot \mathrm{moles}$ of hydrogen burned and $61 \mathrm{~g} \cdot$ moles of hydrogen remained unreacted.

Two gas grab samples were taken from inside the subcompartment structures. These bottles were opened at $2 \mathrm{~s}$ after the initiation of the HPME and were closed $5 \mathrm{~s}$ later. These samples 
showed hydrogen concentrations of 3.88 and $3.85 \mathrm{~mol} . \% \mathrm{H}_{2}$. This indicates that there were high $\mathrm{H}_{2}$ concentrations inside the subcompartment structures soon after the HPME. These samples also indicated oxygen concentrations of 7.90 and $8.00 \mathrm{~mol} \% \mathrm{O}_{2}$. Thus, there was some oxygen depletion inside the subcompartment structures shortly after the beginning of the HPME, either from displacement or hydrogen combustion. The above background concentration of $\mathrm{CO}$ and $\mathrm{CO}_{2}$ was due to the ablatic n of concrete, the graphite limitor plate, and the burning of paint on structures.

Two gas grab samples were taken from the cavity in the IET-4 experiment. The results of these samples indicate that there were high hydrogen concentrations in the cavity during the HPME transient (23.8 and $35.4 \mathrm{~mol} \%$ ). The result indicates that the entraining gas in the cavity was a mixture of steam and hydrogen, and is important because many analytical entrainment models require the composition of the entraining gas.

\subsection{Debris Recovery Summary}

The posttest water on the containment basement floor was $1.27 \mathrm{~cm}$ deep, compared to an initial depth of $1.52 \mathrm{~cm}$. Evaporation of the water was complete in a few days. Debris in the Surtsey vessel was recovered from four basic locations: (1) from inside the subcompartment structures, (2) from the Surtsey vessel outside the structures, (3) from the cavity and instrument tunnel chute, and (4) from the crucible. Table 4 gives the debris recovery summary of the IET-4 experiment, and compares it to the IET-1 [Allen et al. 1992d] and IET-3 experiments [Allen et al. 1992c]. The total molten mass available for dispersal into the vessel is usually about 20 percent greater than the initial thermite charge due to the melting of the inner wall of the crucible, vaporization of the fusible brass plug, ablation of concrete in the cavity and structures, and oxidation of meiallic debris. Table 4 indicates that $\approx 81$ percent of the molten debris that was ejected into the (avity was dispersed into the vessel in IET-4, $\approx 67$ percent in IET-3, and $\approx 86$ percent in IET-1. Total debris dispersed into Surtsey in IET- 4 was $40.7 \mathrm{~kg}$, compared to $34.3 \mathrm{~kg}$ in IET -3 , and $43.0 \mathrm{~kg}$ in IET-1. The reason for the difference in debris dispersal may be due to the stochastic nature of debris entrainment from the cavity.

Table 4 also shows the mass balance based on transport fractions. The entries for the transport fractions indicate how they are computed from the mass balance. The transport fractions depend on the mass recovered from the locations specified in Table 4. For example, the mass transported to the upper dome is computed from

$$
M_{d, d o m e}=f_{\text {cject }} f_{\text {disp }} f_{\text {dome }} M_{d}^{0}
$$

This method predicts that $5.30 \mathrm{~kg}$ of thermite were transported to the upper dome, which is less than $\quad 8.04 \mathrm{~kg}$ of material that were actually recovered in the upper dome. The difference represents contaminants and oxygen uptake. The transport fractions are computed based on the assumption that the bulk of contaminants and oxygen uptake occurred in the cavity. This introduces an element of subjectivity into the definition of transport fractions; however, the adopted procedure is recommended because it more closely represents the fraction of thermite dispersed to each location. 
The debris plume apparently impacted the crane wall and the concrete ceiling near the seal table. Some of the debris was deflected to the containment basement floor, and some of the debris entered the seal table room. Debris impacting the crane wall inside the seal table room apparently caused it to fail. Some debris was ejected through the hole in the crane wall. Of the $32.6 \mathrm{~kg}$ recovered from within the subcompartment structures, $8.0 \mathrm{~kg}$ was in the seal table room. The concrete plug in the ceiling of the seal table room (i.e., in the operating deck) was intentionally left out, as it had been in IET-3.

A video taken from a port in the upper head of the Surtsey vessel shows a violent hydrogen burn above the operating deck in the scaled structures. Early in the HPME transient, the video shows a horizontal, bright orange flame jetting violently out of the seal table room door. The video taken from the upper port shows orange flames leaping out of the vent spaces above the reactor coolant pumps and then filling the entire vessel and propagating toward the upper head, but only reaching about the midpoint of Surtsey. Individual, luminous debris particles are evident in IET-4.

Figure 36 shows particle size analysis from debris recovered from the Surtsey vessel outside the subcompartment structures. The particle size analysis discounted all debris with size $>9.4$ $\mathrm{mm}$. The particle size distribution is not lognormal, and was similar to the results of the IET -3 experiment. The sieve mass median diameter of debris recovered outside the subcompartment structures was $0.52 \mathrm{~mm}$.

\subsection{Energy Balance}

A single-cell equilibrium model was usec: to perform an energy balance on the IET experiments [Allen et al. 1992c,d], neglecting the presence of water in the cavity. Simple calculations based on the actual IET initial conditions were performed to determine the amount of energy that might be added to the Surtsey vessel atmosphere by the steam blowdown, exothermic steam/metal chemical reactions, debris/gas heat transfer, and hydrogen combustion. The total amount of energy was used to calculate an upper limit to the possible pressure increase in the Surtsey vessel, $\Delta \mathrm{P}_{\text {equilibrium. }}$. The result could then be compared to the measured peak pressure increase, $\Delta \mathrm{P}_{\text {measured }}$, to determine the total DCH efficiency, $\eta=$ $\Delta \mathrm{P}_{\text {measured }} d \Delta \mathrm{P}_{\text {equilibrium, }}$ in the IET experiments [Allen et al. 1992c,d,].

The presence of water in the cavity during the IET experiments provided a potential heat sink in the system, since some portion of the thermal and chemical energy in the debris would be used to vaporize the water. In the WC- 2 experiment [Allen et al. 1991a], the results indicated that less than 15 percent of the water initially present in the cavity was vaporized, despite the fact that the thermite in that experiment contained approximately five times the amount of energy necessary to vaporize all of the water that was present. This result suggests that water was ineffective as a heat sink. Furthermore, the HIPS tests with water in the cavity [Tarbell et al. 1991] suggest that the bulk of the water was ejected prior to debris dispersal. In the IET experiments [Allen et al. 1992c,d,], the thermite contained approximately 17 times the amount of energy necessary to vaporize all of the water that was present in the cavity. The actual amount of water that was vaporized in the IET experiments cannot be determined from the experimental results, but there was probably very little water vaporized in the cavity. 
Derivation of the single-cell model has been documented by Pilch [1991]. The resulting model is given here. Thermal equilibrium between airborne debris and the containment atmosphere yields a simple, bounding expression for the DCH load,

$$
\frac{\Delta U}{U^{o}}=\frac{\Delta P}{P^{o}}=\frac{\sum_{i} \Delta E_{i}}{U^{o}(1+\psi)},
$$

where

$$
\begin{aligned}
& \Delta \mathrm{U}=\text { total internal energy gained by the containment atmosphere, } \\
& \mathrm{U}^{\circ}=\text { initial internal energy of the entire containment atmosphere, } \\
& \Delta \mathrm{P}=\text { pressure rise in the containment resulting from the } \mathrm{DCH} \text { event, } \\
& \mathrm{P}^{\circ}=\text { initial containment pressure, } \\
& \Delta \mathrm{E}_{\mathrm{i}}=\text { maximum energy that could be added to the containment atmosphere by the } \\
& \mathrm{i}^{\text {th }} \text { process, where the } \mathrm{i} \text { processes are steam blowdown, debris/gas heat } \\
& \text { transfer, debris oxidation by steam in an otherwise inert atmosphere, and } \\
& \psi=\text { heat capacity ratio. }
\end{aligned}
$$

The heat capacity ratio appears because the debris still carries sensible heat that is not available for containment pressurization at thermal equilibrium between airborne debris and the atmosphere. The heat capacity ratio is defined by

$$
\psi=\frac{N_{d} C_{d}}{\left(N^{0}+N_{b}\right) C_{v}}
$$

where

$$
\begin{array}{lll}
\mathrm{N}_{\mathrm{d}}= & \text { number of } g \cdot \text { moles of debris participating in DCH, } \\
\mathrm{C}_{\mathrm{d}}= & \text { molar heat capacity of debris, } \\
\mathrm{N}^{0}= & \text { number of gas g.moles initially in the containment, } \\
\mathrm{N}_{\mathrm{b}}= & \begin{array}{l}
\text { number of gas g.moles added to the containment by RCS blowdown, } \\
\text { and }
\end{array} \\
\mathrm{C}_{\mathrm{v}}= & \text { molar heat capacity of the containment atmosphere. }
\end{array}
$$

The g.moles of debris participating in $\mathrm{DCH}$ can be expressed in terms of the initial charge of thermite by

$$
N_{d}=f_{c j e c l} f_{d i s p} \frac{M_{d}{ }^{o}}{M W_{d}}
$$


where

$\mathrm{f}_{\mathrm{eject}}=$ fraction of the initial charge that is ejected from the melt generator to the cavity,

$\mathrm{f}_{\text {disp }}=$ fraction of the melt ejected into the cavity that is subsequently dispersed into the containment,

$\mathbf{M}_{\mathrm{d}}{ }^{\mathrm{o}}=$ initial (mass) charge of thermite, and

$\mathrm{MW}_{\mathrm{d}}=\quad$ the effectiv molecular weight of thermite, $0.0631 \mathrm{~kg} / \mathrm{g} \cdot \mathrm{mole}$.

Table 4 lists all the information necessary to complete this calculation.

Blowdown of the steam accurıulator adds both mass and energy to the containment atmosphere. The maximum amount of energy that the accumulator can contribute to Surtsey pressurization is given by

$$
\Delta E_{b}=\frac{P_{a c c}^{o} V_{a c c}}{\gamma-1}\left(1-\frac{P^{o}}{P_{a c c}^{o}}\right),
$$

where

$$
\begin{array}{ll}
\mathrm{P}_{\mathrm{acc}}{ }^{\circ}= & \begin{array}{l}
\text { equilibrium pressure of the accumulator/melt generator system just prior } \\
\text { to plug failure, }
\end{array} \\
\mathrm{V}_{\text {acc }}= & \text { total free volume of the accumulater and melt generator, and } \\
\gamma & =\text { ratio of specific heats. }
\end{array}
$$

The term preceding the brackets represents the total internal energy of the accumulator, while the bracketed term represents the fraction of this total that is convected into the containment.

Molten debris dispersed from the reactor cavity carries both latent and sensible heat that can be transferred to the atmosphere. The maximum energy source associated with debris thermal energy,

$$
\Delta E_{t}=N_{d} \Delta e_{i},
$$

is equal to the amount of dispersed debris, $\mathrm{N}_{d}$, times the specific molar internal energy of the debris, $\Delta \mathrm{e}_{\mathrm{t}}$, which has a value of $0.147 \mathrm{MJ} / \mathrm{g} \cdot \mathrm{mole}$ for thermite.

The energy source due to debris oxidation,

$$
\Delta E_{r}=N_{d} \Delta e_{r},
$$

is equal to the amount of debris participating in DCH times the specific molar oxidation energy of the debris. Assuming all the metals react with steam, the specific molar oxidation energy, $\Delta \mathrm{e}_{\mathrm{r}}$, has a value of $0.054 \mathrm{MJ} / \mathrm{g} \cdot$ mole for thermite. 
The energy source due to hydrogen combustion is

$$
\Delta E_{H_{2}}=N_{H_{2}, o t} \Delta e_{H_{2}}=\left(N_{H_{2}, p r e}+U_{H_{2}} N_{d}\right) \Delta e_{H_{2}}
$$

where

$$
\begin{aligned}
& \mathrm{N}_{\mathrm{H} 2 \text {,pre }}=\mathrm{g} \cdot \mathrm{moles} \text { of pre-existing hydrogen in the containment atmosphere } \\
& \text { prior to the DCH event, } \\
& \mathrm{U}_{\mathrm{H} 2}=\text { the effective stoichiometric coefficient for debris oxidation, } \\
& 0.892 \mathrm{~g} \cdot \text { moles}-\mathrm{H}_{2} / \mathrm{g} \cdot \text { mole-debris, and } \\
& \Delta \mathrm{e}_{\mathrm{H} 2} \quad=\quad \text { the specific combustion energy for hydrogen, } \\
& 0.242 \mathrm{MJ} / \mathrm{g} \cdot \mathrm{mole}-\mathrm{H}_{2} \text {. }
\end{aligned}
$$

The second term in the brackets, $\mathrm{U}_{\mathrm{H} 2} \mathrm{~N}_{\mathrm{d}}$, represents the totals of $\mathrm{g}$-moles of hydrogen that can be produced from complete oxidation of the metallic constituents of the dispersed debris. There is sufficient steam in the accumulator and water in the cavity or on the basement floor to achieve complete oxidation of debris.

The initial internal energy of the atmosphere is computed from

$$
U^{o}=N^{\circ} C_{\nu} T^{o}
$$

where

$$
\mathrm{T}^{\mathbf{0}}=\quad \text { initial temperature of the Surtsey atmosphere. }
$$

Table 5 summarizes the energy balance for IET-1, IET-3, and IET-4. The thermal (latent and sensible heats) and chemical energy (debris oxidation) are computed for the dispersed thermite mass only. For IET-1, the calculated pressure rise at equilibrium is $0.384 \mathrm{MPa}$ compared to a measured pressure of $0.098 \mathrm{MPa}$; thus the DCH efficiency for IET-1 is 26 percent. For IET-3, the calculated pressure rise at equilibrium is $0.608 \mathrm{MPa}$ compared to a measured pressure of $0.246 \mathrm{MPa}$. The DCH efficiency for IET-3 is 40 percent. The calculated pressure rise at equilibrium for IET-4 is $0.704 \mathrm{MPa}$ compared to a measured pressure rise of $0.262 \mathrm{MPa}$. The DCH efficiency for IET-4 was 37.2 percent. The efficient combustion for hydrogen ( $\approx 80$ percent) produced during the DCH event in IET-3 and IET-4 resulted in a pressure rise that more than doubled the pressure rise observed in IET-1. This large contribution due to efficient hydrogen combustion is reflected in the substantially larger overall efficiencies reported for IET-3 and IET-4.

\subsection{SUMMARY}

A comparison of the IET-1, IET-3, and IET-4 experiments gave a quantitative measurement of the incremental increase in peak pressure in the Surtsey vessel due to combustion of hydrogen produced by the steam-driven HPME. Pressure and temperature measurements showed that a vigorous hydrogen burn occurred as gas was pushed out of the subcompartment structures. IET-3 gave the first experimental evidence that DCH conditions can result in almost complete combustion of hydrogen. IET-4 confirmed this evidence. 
An unusual phenomenon was seen in IET-4. 'This was the negative pressures (relative to vessel pressure) measured in the subcompartment structures, and also in the seal table room. This effect may be attributed to the water on the basement floor inside the crane wall. Overall, water on the basement floor inside the crane wall appeared to have little effect on the Surtsey vessel peak pressure. The additional hydrogen burned in IET-4 (236 g.moles) compared to IET-3 ( $\approx 186 \mathrm{~g} \cdot \mathrm{moles})$ and the additional debris dispersed outside the subcompariment structures in IET-4 $(8 \mathrm{~kg})$ compared to IET $-3(3 \mathrm{~kg})$ were apparently at least partially compensated for by quenching of debris by water on the containment basement floor.

Table 6 summarizes the comparative results of the IET-1, IET-3, and IET-4 experiments. 
Table 1

IET-4 Instrumentation Location and Purpose

\begin{tabular}{|c|c|c|c|}
\hline $\begin{array}{l}\text { Channel } \\
\text { Number }\end{array}$ & Instrument & Location & Purpose \\
\hline 1 & Disk Calorimeter & In Crane Wall & $\begin{array}{l}\text { Measure Debris Contact } \\
\text { Temperature }\end{array}$ \\
\hline 2 & Disk Calorimeter" & $\begin{array}{l}\text { On Vessel Floor } \\
\text { Next to Chute }\end{array}$ & $\begin{array}{l}\text { Measure Debris Contact } \\
\text { Temperature }\end{array}$ \\
\hline 3 & Disk Calorimeter* & $\begin{array}{l}\text { On Vessel Floor } \\
\text { Next to Shield }\end{array}$ & $\begin{array}{l}\text { Measure Debris Contact } \\
\text { Temperature }\end{array}$ \\
\hline 4 & Disk Calorimeter" & $\begin{array}{l}\text { In Ceiling over } \\
\text { Chute }\end{array}$ & $\begin{array}{l}\text { Measure Debris Contact } \\
\text { Temperature }\end{array}$ \\
\hline 7 & Thermocouple & Chute Exit & $\begin{array}{l}\text { Measure Temperaturc } \\
\text { Inside Subcompartment } \\
\text { Structures }\end{array}$ \\
\hline 8 & Thermocouple & $\begin{array}{l}\text { Seal Table Room } \\
\text { Floor }\end{array}$ & $\begin{array}{l}\text { Measure Temperature } \\
\text { Inside Subcompartment } \\
\text { Structures }\end{array}$ \\
\hline 16 & Breakwire & $\begin{array}{l}\text { Seal Table Room } \\
\text { Plug }\end{array}$ & $\begin{array}{l}\text { Measure Debris } \\
\text { Velocity }\end{array}$ \\
\hline 17 & Breakwire & $\begin{array}{l}\text { On Seal Table } \\
\text { Room Floor } \\
\end{array}$ & $\begin{array}{l}\text { Measure Debris } \\
\text { Velocity }\end{array}$ \\
\hline 18 & Photodiode & Photodiode & $\begin{array}{l}\text { Signal Initiation of } \\
\text { HPME }\end{array}$ \\
\hline 19 & $\begin{array}{l}\text { Pressure } \\
\text { Transducer }\end{array}$ & $\begin{array}{l}\text { Refueling Canal } \\
\text { Wall }\end{array}$ & $\begin{array}{l}\text { Measure Gas Pressure } \\
\text { Inside Subcompartment } \\
\text { Structures }\end{array}$ \\
\hline 20 & $\begin{array}{l}\text { Pressure } \\
\text { Transducer }\end{array}$ & Seal Table Room & $\begin{array}{l}\text { Measure Gas Pressure } \\
\text { Inside Seal Table Room }\end{array}$ \\
\hline 21 & $\begin{array}{l}\text { Pressure } \\
\text { Transducer }\end{array}$ & Level 1 & $\begin{array}{l}\text { Measure Gas Pressure } \\
\text { in Surtsey Vessel }\end{array}$ \\
\hline 22 & \begin{tabular}{|l} 
Pressure \\
Transducer \\
\end{tabular} & Level 1 & $\begin{array}{l}\text { Measure Gas Pressure } \\
\text { in Surtsey Vessel }\end{array}$ \\
\hline 23 & $\begin{array}{l}\text { Pressure } \\
\text { Transducer }\end{array}$ & Level 3 & $\begin{array}{l}\text { Measure Gas Pressure } \\
\text { in Surtsey Vessel }\end{array}$ \\
\hline
\end{tabular}




\begin{tabular}{|c|c|c|c|}
\hline $\begin{array}{l}\text { Channel } \\
\text { Number }\end{array}$ & Instrument & Location & Purpose \\
\hline 24 & $\begin{array}{l}\text { Pressure } \\
\text { Transducer }\end{array}$ & Level 3 & $\begin{array}{l}\text { Measure Gas Pressure } \\
\text { in Surtsey Vessel }\end{array}$ \\
\hline 25 & $\begin{array}{l}\text { Pressure } \\
\text { Transducer }\end{array}$ & Level 5 & $\begin{array}{l}\text { Measure Gas Pressure } \\
\text { in Surtsey Vessel }\end{array}$ \\
\hline 26 & $\begin{array}{l}\text { Pressure } \\
\text { Transducer }\end{array}$ & Level 5 & $\begin{array}{l}\text { Measure Gas Pressure } \\
\text { in Surtsey Vessel }\end{array}$ \\
\hline 32 & $\begin{array}{l}\text { Pressure } \\
\text { Transducer }\end{array}$ & Accumulator & $\begin{array}{l}\text { Measure Gas Pressure } \\
\text { in Accumulator Tank }\end{array}$ \\
\hline 33 & $\begin{array}{l}\text { Pressure } \\
\text { Transducer }\end{array}$ & Burst Diaphragm & Measure Gas Pressure \\
\hline 34 & $\begin{array}{l}\text { Pressure } \\
\text { Transducer }\end{array}$ & Crucible & Measure Gas Pressure \\
\hline 35 & $\begin{array}{l}\text { Pressure } \\
\text { Transducer }\end{array}$ & Crucible & Measure Gas Pressure \\
\hline 36 & $\begin{array}{l}\text { Pressure } \\
\text { Transducer }\end{array}$ & Cavity & $\begin{array}{l}\text { Measure Gas Pressure } \\
\text { in the Cavity }\end{array}$ \\
\hline 37 & $\begin{array}{l}\text { Optical Pyrometer } \\
\text { Type } 11 \times 20\end{array}$ & $\begin{array}{l}\text { Inside Biological } \\
\text { Shield Wall - } \\
\text { Focused Above } \\
\text { Instrument Tunnel } \\
\text { Exit }\end{array}$ & $\begin{array}{l}\text { Measure Debris } \\
\text { Temperature as it } \\
\text { Entered } \\
\text { Subcompartment } \\
\text { Structures }\end{array}$ \\
\hline 38 & $\begin{array}{l}\text { Optical Pyrometer } \\
\text { Type } 11 \times 30\end{array}$ & $\begin{array}{l}\text { Outside Crane } \\
\text { Wall - Focused } \\
\text { Above Instrument } \\
\text { Tunnel Exit }\end{array}$ & $\begin{array}{l}\text { Measure Debris } \\
\text { Temperature as it } \\
\text { Entered } \\
\text { Subcompartment } \\
\text { Structures }\end{array}$ \\
\hline 39 & $\begin{array}{l}\text { Pressure } \\
\text { Transducer }\end{array}$ & Refueling Canal & $\begin{array}{l}\text { Measure Gas Pressure } \\
\text { Inside Subcompartment } \\
\text { Structures }\end{array}$ \\
\hline 40) & $\begin{array}{l}\text { Pressure } \\
\text { Transducer }\end{array}$ & Seal Table Room & $\begin{array}{l}\text { Measure Gas Pressure } \\
\text { Inside Seal Table Room }\end{array}$ \\
\hline 41 & $\begin{array}{l}\text { Aspirated } \\
\text { Thermocouple }\end{array}$ & Level 3 & $\begin{array}{l}\text { Measure Gas } \\
\text { Temperature at Surtsey } \\
\text { Vessel Walls }\end{array}$ \\
\hline 42 & $\begin{array}{l}\text { Aspirated } \\
\text { Thermocouple }\end{array}$ & Level 3 & $\begin{array}{l}\text { Measure Gas } \\
\text { Temperature at Surtsey } \\
\text { Vessel Walls }\end{array}$ \\
\hline
\end{tabular}




\begin{tabular}{|c|c|c|c|}
\hline $\begin{array}{l}\text { Channel } \\
\text { Number }\end{array}$ & Instrument & Location & Purpose \\
\hline 43 & $\begin{array}{l}\text { Aspirated } \\
\text { Thermocouple }\end{array}$ & Level 1 & $\begin{array}{l}\text { Measure Gas } \\
\text { Temperature at Surtsey } \\
\text { Vessel Walls }\end{array}$ \\
\hline 44 & $\begin{array}{l}\text { Aspirated } \\
\text { Thermocouple }\end{array}$ & Level 1 & $\begin{array}{l}\text { Measure Gas } \\
\text { Temperature at Surtsey } \\
\text { Vessel Walls }\end{array}$ \\
\hline 45 & $\begin{array}{l}\text { Aspirated } \\
\text { Thermocouple }\end{array}$ & Level 1 & $\begin{array}{l}\text { Measure Gas } \\
\text { Temperature at Surtsey } \\
\text { Vessel Walls }\end{array}$ \\
\hline 46 & $\begin{array}{l}\text { Aspirated } \\
\text { Thermocouple }\end{array}$ & Level 5 & $\begin{array}{l}\text { Measure Gas } \\
\text { Temperature at Surtsey } \\
\text { Vessel Walls }\end{array}$ \\
\hline 47 & $\begin{array}{l}\text { Aspirated } \\
\text { Thermocouple }\end{array}$ & Level 5 & $\begin{array}{l}\text { Measure Gas } \\
\text { Temperature at Surtsey } \\
\text { Vessel Walls }\end{array}$ \\
\hline 48 & $\begin{array}{l}\text { Aspirated } \\
\text { Thermocouple }\end{array}$ & Level 5 & $\begin{array}{l}\text { Measure Gas } \\
\text { Temperature at Surtsey } \\
\text { Vessel Walls }\end{array}$ \\
\hline 49 & $\begin{array}{l}\text { Aspirated } \\
\text { Thermocouple }\end{array}$ & Level 3 & $\begin{array}{l}\text { Measure Gas } \\
\text { Temperature at Surtsey } \\
\text { Vessel Walls }\end{array}$ \\
\hline 50 & Ignitor & Crucible & $\begin{array}{l}\text { Timing Signal for } \\
\text { Thermite Ignition }\end{array}$ \\
\hline 51 & $\begin{array}{l}\text { Aspirated } \\
\text { Thermocouple }\end{array}$ & $\begin{array}{l}\text { Refueling Canal } \\
\text { Wall }\end{array}$ & $\begin{array}{l}\text { Measure Gas } \\
\text { Temperature Inside } \\
\text { Subcompartment } \\
\text { Structures }\end{array}$ \\
\hline 52 & $\begin{array}{l}\text { Aspirated } \\
\text { Thermocouple }\end{array}$ & $\begin{array}{l}\text { Refueling Canal } \\
\text { Wall }\end{array}$ & $\begin{array}{l}\text { Measure Gas } \\
\text { Temperature Inside } \\
\text { Subcompartment } \\
\text { Structures }\end{array}$ \\
\hline 53 & $\begin{array}{l}\text { Aspirated } \\
\text { Thermocouple }\end{array}$ & $\begin{array}{l}\text { Refueling Canal } \\
\text { Wall }\end{array}$ & $\begin{array}{l}\text { Measure Gas } \\
\text { Temperature Inside } \\
\text { Subcompartment } \\
\text { Structures }\end{array}$ \\
\hline 54 & $\begin{array}{l}\text { Aspirated } \\
\text { Thermocouple }\end{array}$ & Seal Table Room & $\begin{array}{l}\text { Measure Gas } \\
\text { Temperature Inside Seal } \\
\text { Table Room }\end{array}$ \\
\hline
\end{tabular}




\begin{tabular}{|c|c|c|c|}
\hline $\begin{array}{l}\text { Channel } \\
\text { Number }\end{array}$ & Instrument & Location & Purpose \\
\hline 55 & $\begin{array}{l}\text { Aspirated } \\
\text { Thermocouple }\end{array}$ & Seal Table Room & $\begin{array}{l}\text { Measure Gas } \\
\text { Temperature Inside Seal } \\
\text { Table Room }\end{array}$ \\
\hline 56 & $\begin{array}{l}\text { Aspirated } \\
\text { Thermocouple }\end{array}$ & Seal Table Room & $\begin{array}{l}\text { Measure Gas } \\
\text { Temperature Inside Seal } \\
\text { Table Room }\end{array}$ \\
\hline 57 & Thermocouple & Cavity Floor & $\begin{array}{l}\text { Measure Gas } \\
\text { Temperature Inside } \\
\text { Cavity }\end{array}$ \\
\hline 58 & Thermocouple & Crucible & $\begin{array}{l}\text { Measure Gas } \\
\text { Temperature Inside } \\
\text { Crucible }\end{array}$ \\
\hline 59 & $\begin{array}{l}\text { Pressure } \\
\text { Transducer }\end{array}$ & Coolant Pump 1A & $\begin{array}{l}\text { Measure Pressure } \\
\text { Caused by Heating RCP } \\
\text { 1A }\end{array}$ \\
\hline 62 & $\begin{array}{l}\text { Pressure } \\
\text { Transducer }\end{array}$ & Coolant Pump 1B & $\begin{array}{l}\text { Measure Pressure } \\
\text { Caused by Heating RCP } \\
\text { 1B }\end{array}$ \\
\hline 63 & $\begin{array}{l}\text { Pressure } \\
\text { Transducer }\end{array}$ & Coolant Pump 1C & $\begin{array}{l}\text { Measure Pressure } \\
\text { Caused by Heating RCP } \\
\text { 1C }\end{array}$ \\
\hline 64 & $\begin{array}{l}\text { Pressure } \\
\text { Transducer }\end{array}$ & Coolant Pump 1D & $\begin{array}{l}\text { Measure Pressure } \\
\text { Caused by Heating RCP } \\
\text { 1D }\end{array}$ \\
\hline 65 & $\begin{array}{l}\text { Pressure } \\
\text { Transducer }\end{array}$ & Lower Head & $\begin{array}{l}\text { Measure Pressure Under } \\
\text { Containment Basement } \\
\text { Floor }\end{array}$ \\
\hline 66 & Thermocouple & Vent Space 1A & $\begin{array}{l}\text { Measure Gas } \\
\text { Temperature Above } \\
\text { RCP 1A }\end{array}$ \\
\hline 67 & Thermocouple & Vent Space 1D & $\begin{array}{l}\text { Measure Gas } \\
\text { Temperature Above } \\
\text { RCP 1D }\end{array}$ \\
\hline 68 & $\begin{array}{l}\text { East Thermocouple } \\
\text { Array }\end{array}$ & Bottom & $\begin{array}{l}\text { Measure Local Gas } \\
\text { Temperature }\end{array}$ \\
\hline 69 & $\begin{array}{l}\text { East Thermocouple } \\
\text { Array }\end{array}$ & Bottom/Middle & $\begin{array}{l}\text { Measure Local Gas } \\
\text { Temperature }\end{array}$ \\
\hline
\end{tabular}




\begin{tabular}{|r|l|l|l||}
\hline $\begin{array}{r}\text { Channel } \\
\text { Number }\end{array}$ & \multicolumn{1}{|c|}{ Instrument } & \multicolumn{1}{|c|}{ Location } & \multicolumn{1}{c|}{ Purpose } \\
\hline 70 & $\begin{array}{l}\text { East Thermocouple } \\
\text { Array }\end{array}$ & Middle & $\begin{array}{l}\text { Measure Local Gas } \\
\text { Temperature }\end{array}$ \\
\hline 71 & $\begin{array}{l}\text { East Thermocouple } \\
\text { Array }\end{array}$ & Middle/Top & $\begin{array}{l}\text { Measure Local Gas } \\
\text { Temperature }\end{array}$ \\
\hline 72 & $\begin{array}{l}\text { East Thermocouple } \\
\text { Array }\end{array}$ & Top & $\begin{array}{l}\text { Measure Local Gas } \\
\text { Temperature }\end{array}$ \\
\hline 73 & $\begin{array}{l}\text { West } \\
\text { Thermocouple } \\
\text { Array }\end{array}$ & Bottom & $\begin{array}{l}\text { Measure Local Gas } \\
\text { Temperature }\end{array}$ \\
\hline 74 & $\begin{array}{l}\text { West } \\
\text { Thermocouple } \\
\text { Array }\end{array}$ & Bottom/Middle & $\begin{array}{l}\text { Measure Local Gas } \\
\text { Temperature }\end{array}$ \\
\hline 75 & $\begin{array}{l}\text { West } \\
\text { Thermocouple } \\
\text { Array }\end{array}$ & Middle & $\begin{array}{l}\text { Measure Local Gas } \\
\text { Temperature }\end{array}$ \\
\hline 76 & $\begin{array}{l}\text { West } \\
\text { Thermocouple } \\
\text { Array }\end{array}$ & Middle/Top & $\begin{array}{l}\text { Measure Local Gas } \\
\text { Temperature }\end{array}$ \\
\hline 77 & $\begin{array}{l}\text { West } \\
\text { Thermocouple } \\
\text { Array }\end{array}$ & Top & $\begin{array}{l}\text { Measure Local Gas } \\
\text { Temperature }\end{array}$ \\
\hline 80 & $\begin{array}{l}\text { Pressure } \\
\text { Transducer }\end{array}$ & Level 5 & $\begin{array}{l}\text { Measure Gas Pressure } \\
\text { in Surtsey Upper Dome }\end{array}$ \\
\hline 82 & $\begin{array}{l}\text { Thermocouple } \\
\text { Teasure Gas } \\
0.32 \text { cm From Inner } \\
\text { Wall }\end{array}$ \\
\hline & Accumulator & $\begin{array}{l}\text { Measure Gas } \\
\text { Temperature } \\
\text { Wall cm From Inner }\end{array}$ \\
\hline $\begin{array}{l}\text { Thermocouple } \\
\text { Wall }\end{array}$ \\
\hline
\end{tabular}




\begin{tabular}{|c|c|c|c|}
\hline $\begin{array}{l}\text { Channel } \\
\text { Number }\end{array}$ & Instrument & Location & Purpose \\
\hline 84 & Thermocouple & Accumulator & $\begin{array}{l}\text { Measure Gas } \\
\text { Temperature } \\
0.32 \mathrm{~cm} \text { From Inner } \\
\text { Wall }\end{array}$ \\
\hline 85 & Thermocouple & Accumulator & $\begin{array}{l}\text { Measure Gas } \\
\text { Temperature } \\
0.32 \mathrm{~cm} \text { From Inner } \\
\text { Wall }\end{array}$ \\
\hline 86 & Thermocouple & Accumulator & $\begin{array}{l}\text { Measure Gas } \\
\text { Temperature } \\
0.32 \mathrm{~cm} \text { From Inner } \\
\text { Wall }\end{array}$ \\
\hline 87 & Thermocouple & Accumulator & $\begin{array}{l}\text { Measure Flange Outside } \\
\text { Surface Temperature }\end{array}$ \\
\hline 88 & Thermocouple & Accumulator & $\begin{array}{l}\text { Measure Accumulator } \\
\text { Outside } \\
\text { Surface Temperature }\end{array}$ \\
\hline 90 & Thermocouple & Accumulator & $\begin{array}{l}\text { Measure Accumulator } \\
\text { Outside } \\
\text { Surface Temperature }\end{array}$ \\
\hline 91 & Thermocouple & Accumulator & $\begin{array}{l}\text { Measure Gas } \\
\text { Temperature Inside } \\
\text { Accumulator Tank }\end{array}$ \\
\hline 92 & Thermocouple & Accurnulator & $\begin{array}{l}\text { Measure Gas } \\
\text { Temperature Inside } \\
\text { Accumulator Tank }\end{array}$ \\
\hline 93 & Thermocouple & $\begin{array}{l}10.2-\mathrm{cm} \text { Pipe } \\
\text { between } \\
\text { Accumulator and } \\
\text { Melt Generator }\end{array}$ & $\begin{array}{l}\text { Measure Gas } \\
\text { Temperature Inside Pipe } \\
\text { with Burst Diaphragm }\end{array}$ \\
\hline 103 & Thermocouple & $\begin{array}{l}10.2 \mathrm{~cm} \text { Pipe Elbow } \\
\text { Between Melt } \\
\text { Generator and } \\
\text { Crucible }\end{array}$ & $\begin{array}{l}\text { Measure Skin } \\
\text { Temperature }\end{array}$ \\
\hline P1 & $\begin{array}{l}\text { Piezoelectric } \\
\text { Pressure } \\
\text { Transducer }\end{array}$ & East Side of Cavity & $\begin{array}{l}\text { Measure Pressure in } \\
\text { Cavity Wall Under the } \\
\text { Melt Generator }\end{array}$ \\
\hline
\end{tabular}




\begin{tabular}{|c|c|c|c|}
\hline $\begin{array}{l}\text { Channel } \\
\text { Number }\end{array}$ & Instrument & Location & Purpose \\
\hline $\mathrm{P} 2$ & $\begin{array}{l}\text { Piezoelectric } \\
\text { Pressure } \\
\text { Transducer }\end{array}$ & West Side of Cavity & $\begin{array}{l}\text { Measure Pressure in } \\
\text { Cavity } \\
\text { Wall Under the Melt } \\
\text { Generator }\end{array}$ \\
\hline P3 & $\begin{array}{l}\text { Piezoelectric } \\
\text { Pressure } \\
\text { Transducer }\end{array}$ & Crane Wall & $\begin{array}{l}\text { Measure Gas Pressure } \\
\text { Inside Subcompartment } \\
\text { Structures }\end{array}$ \\
\hline P4 & $\begin{array}{l}\text { Piezoelectric } \\
\mathrm{Pi}_{\mathrm{i}} \text { sure } \\
\text { Trarsducer }\end{array}$ & Refueling Canal & $\begin{array}{l}\text { Measure Gas Pressure } \\
\text { Inside } \\
\text { Subcompartment } \\
\text { Structures }\end{array}$ \\
\hline L2 & Gas Grab Sample & Surtsey Level 2 & $\begin{array}{l}\text { Measure Gas } \\
\text { Composition Prior } \\
\text { to and After HPME }\end{array}$ \\
\hline L4 & Gas Grab Sample & Surtsey Level 4 & $\begin{array}{l}\text { Measure Gas } \\
\text { Composition Prior } \\
\text { to and After HPME }\end{array}$ \\
\hline L6 & Gas Grab Sample & Surtsey Level 6 & $\begin{array}{l}\text { Measure Gas } \\
\text { Composition Prior to } \\
\text { and After HPME }\end{array}$ \\
\hline C & Gas Grab Sample & Cavity & $\begin{array}{l}\text { Measure Gas } \\
\text { Composition Prior to } \\
\text { and After HPME }\end{array}$ \\
\hline B & Gas Grab Sample & $\begin{array}{l}\text { Subcompartment } \\
\text { Structure }\end{array}$ & $\begin{array}{l}\text { Measure Gas } \\
\text { Composition Prior to } \\
\text { and After HPME }\end{array}$ \\
\hline
\end{tabular}

- Disk Calorimeters Used Type S Thermocouples

Other Thermocouples Were Type K 
Table 2

Initial Conditions for the IET-1, IET-3 and IET-4 Experiments

\begin{tabular}{|c|c|c|c|c|}
\hline & IET-1 & IET-3 & IET-4 \\
\hline \multicolumn{2}{|c|}{$\begin{array}{l}\text { Thermite composition }(\mathrm{kg}) \\
\text { iron oxide } \\
\text { chromium } \\
\text { aluminum } \\
\text { Mass of the initial thermite charge }(\mathrm{kg})\end{array}$} & $\begin{array}{r}29.26 \\
4.65 \\
9.09 \\
43.00\end{array}$ & $\begin{array}{r}29.26 \\
4.65 \\
9.09 \\
43.00\end{array}$ & $\begin{array}{r}29.26 \\
4.65 \\
9.09 \\
43.00\end{array}$ \\
\hline \multicolumn{2}{|l|}{$\begin{array}{l}\text { Hole diameter }(\mathrm{cm}) \\
\text { initial } \\
\text { final }\end{array}$} & $\begin{array}{l}3.5 \\
4.09\end{array}$ & $\begin{array}{c}3.5 \\
4.53\end{array}$ & $\begin{array}{c}3.5 \\
4.22\end{array}$ \\
\hline \multicolumn{2}{|c|}{ Steam pressure at plug failure (MPa) } & 7.1 & 6.1 & 6.7 \\
\hline \multicolumn{2}{|c|}{ Steam temperature at plug failure $(\mathrm{K})$} & 600 & 585 & 555 \\
\hline \multicolumn{2}{|c|}{ Moles of steam driving gas ( $\mathrm{g} \cdot \mathrm{moles})$} & 440 & 456 & 582 \\
\hline \multicolumn{2}{|l|}{ Cavity water (kg) } & $\begin{array}{c}3.48 \\
(0.9 \mathrm{~cm} \\
\text { deep) }\end{array}$ & $\begin{array}{c}3.48 \\
(0.9 \mathrm{~cm} \\
\text { deep })\end{array}$ & $\begin{array}{c}3.48 \\
(0.9 \mathrm{~cm} \\
\text { deep })\end{array}$ \\
\hline \multicolumn{2}{|c|}{$\begin{array}{l}\text { Water on containment basement floor } \\
\text { inside crane wall }(\mathrm{kg})\end{array}$} & 0 & 0 & $\begin{array}{c}71.1 \\
(1.52 \mathrm{~cm} \\
\text { deep })\end{array}$ \\
\hline \multicolumn{2}{|c|}{ Initial absolute pressure in Surtsey (MPa) } & 0.20 & 0.19 & 0.20 \\
\hline \multicolumn{2}{|c|}{ Initial temperature in Surtsey $(\mathrm{K})$} & 295 & 279 & 286 \\
\hline $\begin{array}{l}\text { Initial gas composition } \\
\text { in Surtsey (mol.\%) }\end{array}$ & $\begin{array}{l}\mathrm{N}_{2} \\
\mathrm{O}_{2} \\
\text { Other }\end{array}$ & $\begin{array}{r}99.96 \\
0.03 \\
0.01\end{array}$ & $\begin{array}{c}90.6 \\
9.0 \\
0.4\end{array}$ & $\begin{array}{l}90.0 \\
9.59 \\
0.41\end{array}$ \\
\hline $\begin{array}{l}\text { Freeboard volume inside } \\
\text { subcompartment structur } \\
\text { Freeboard volume in Su } \\
\text { upper dome } \\
\text { Total freeboard volume } \\
\text { inside Surtsey }\end{array}$ & sey & & $\begin{array}{l}4.65 \mathrm{~m}^{3} \\
\underline{85.15 \mathrm{~m}^{3}} \\
89.8 \mathrm{~m}^{3}\end{array}$ & \\
\hline
\end{tabular}


Table 3

\section{Gas Concentrations Measured in the IET-4 Experiment}

\begin{tabular}{|c|c|c|c|c|c|c|}
\hline \multirow[t]{2}{*}{ Location } & \multirow[t]{2}{*}{ Start Time $\rightarrow$ Duration } & \multicolumn{5}{|c|}{$\begin{array}{l}\text { Species } \\
(\mathrm{mol} \%)\end{array}$} \\
\hline & & $\mathrm{N}_{2}$ & $\mathrm{O}_{2}$ & $\mathrm{H}_{2}$ & $\mathrm{CO}$ & $\mathrm{CO}_{2}$ \\
\hline Background & $-20 \mathrm{~s} \rightarrow 10 \mathrm{~s}$ & 90.0 & 9.59 & $<0.01$ & $<0.1$ & 0.02 \\
\hline Cavity & $0.0 \mathrm{~s} \rightarrow 2 \mathrm{~s}$ & 63.4 & 9.22 & 28.8 & 1.80 & 0.65 \\
\hline Cavity & $0.5 \mathrm{~s} \rightarrow 2 \mathrm{~s}$ & 46.9 & 10.40 & 35.4 & 15.30 & 0.70 \\
\hline $\begin{array}{l}\text { Inside } \\
\text { Structures }\end{array}$ & $\begin{array}{r}2 \mathrm{~s} \rightarrow 5 \mathrm{~s} \\
2 \mathrm{~s} \rightarrow 5 \mathrm{~s} \\
2 \mathrm{~min} \rightarrow 10 \mathrm{~s} \\
\end{array}$ & $\begin{array}{l}86.0 \\
85.4 \\
88.9 \\
\end{array}$ & $\begin{array}{l}7.90 \\
8.00 \\
8.07 \\
\end{array}$ & $\begin{array}{l}3.88 \\
3.85 \\
1.02 \\
\end{array}$ & $\begin{array}{l}1.40 \\
0.90 \\
0.31 \\
\end{array}$ & $\begin{array}{l}0.34 \\
0.32 \\
0.42 \\
\end{array}$ \\
\hline Level 2 & $\begin{array}{l}2 \mathrm{~min} \rightarrow 10 \mathrm{~s} \\
30 \mathrm{~min} \rightarrow 10 \mathrm{~s}\end{array}$ & $\begin{array}{l}89.9 \\
90.5 \\
\end{array}$ & $\begin{array}{l}7.98 \\
7.90 \\
\end{array}$ & $\begin{array}{l}0.82 \\
0.86 \\
\end{array}$ & $\begin{array}{r}0.50 \\
<0.10 \\
\end{array}$ & $\begin{array}{l}0.32 \\
0.32 \\
\end{array}$ \\
\hline Level 4 & $\begin{array}{l}2 \mathrm{~min} \rightarrow 10 \mathrm{~s} \\
30 \mathrm{~min} \rightarrow 10 \mathrm{~s}\end{array}$ & $\begin{array}{l}90.4 \\
89.6 \\
\end{array}$ & $\begin{array}{l}8.03 \\
7.99 \\
\end{array}$ & $\begin{array}{l}0.79 \\
0.85 \\
\end{array}$ & $\begin{array}{r}<0.1 \\
0.8 \\
\end{array}$ & $\begin{array}{l}0.32 \\
0.32 \\
\end{array}$ \\
\hline Level 6 & $\begin{array}{l}2 \min \rightarrow 10 \mathrm{~s} \\
30 \mathrm{~min} \rightarrow 10 \mathrm{~s}\end{array}$ & $\begin{array}{l}90.5 \\
90.4 \\
\end{array}$ & $\begin{array}{l}7.96 \\
7.96 \\
\end{array}$ & $\begin{array}{l}0.78 \\
0.86 \\
\end{array}$ & $\begin{array}{l}<0.1 \\
<0.1 \\
\end{array}$ & $\begin{array}{l}0.32 \\
0.32 \\
\end{array}$ \\
\hline \multicolumn{2}{|c|}{$\begin{array}{l}\text { Mean }^{\S} \\
\text { Standard Deviation }\end{array}$} & & $\begin{array}{l}7.975 \\
0.043\end{array}$ & $\begin{array}{l}0.827 \\
0.036\end{array}$ & & \\
\hline
\end{tabular}

Notes:

$\$$ Mean and standard deviations were computed for the six samples taken after the HPME at levels 2, 4, and 6 in the Surtsey vessel. 
Table 4

Debris Recovery Summary for the IET-1, IET-3 and IET-4 Experiments

\begin{tabular}{||l|c|c|c||}
\hline MASS BALANCE (kg) & IET-1 & IET-3 & IET-4 \\
\hline Initial Thermite Charge, $\mathrm{M}_{\mathrm{d}}{ }^{\mathrm{N}}(\mathrm{a})$ & 43.0 & 43.0 & 43.0 \\
\hline Crucible (b) & 4.54 & 4.50 & 9.76 \\
\hline Cavity/Chute (c) & 7.06 & 16.80 & 9.54 \\
\hline Inside Structures (d) & 38.03 & 31.30 & 32.67 \\
\hline Outside Structures (e) & 4.98 & 3.00 & 8.04 \\
\hline Total Recovered & 43.01 & 34.30 & 40.72 \\
\hline TRANSPORT FRACTIONS & 0.894 & 0.895 & 0.773 \\
\hline $\begin{array}{l}\text { Ejected into Cavity, } \\
\mathrm{f}_{\text {eject }}=1 \text { - b/a }\end{array}$ & 0.859 & 0.671 & 0.810 \\
\hline $\begin{array}{l}\text { Dispersed from Cavity, } \\
\mathrm{f}_{\text {disp }}=(\mathrm{d}+\mathrm{e}) /(\mathrm{c}+\mathrm{d}+\mathrm{e})\end{array}$ & 0.116 & 0.087 & 0.197 \\
\hline $\begin{array}{l}\text { Transported Outside Subcompartment, } \\
\mathrm{f}_{\text {dome }}=\mathrm{e} /(\mathrm{d}+\mathrm{e})\end{array}$ & & & \\
\hline
\end{tabular}

Notes: 1. The molten mass available for dispersal into the vessel is usually about $20 \%$ greater than the initial iron oxide/aluminum/chromium thermite charge due to melting of the inner wall of the crucible, vaporization of the fusible brass plug, ablation of concrete in the cavity, and oxidation of metallic debris by steam. 
Table 5

Energy Balance for the IET-1, IET-3 and IET-4 Experiments

\begin{tabular}{||l|c|c|c|c||}
\hline Term & $\begin{array}{c}\text { IET-1 } \\
\text { Value }\end{array}$ & $\begin{array}{c}\text { IET-3 } \\
\text { Value }\end{array}$ & $\begin{array}{c}\text { IET-4 } \\
\text { Value }\end{array}$ & Description \\
\hline$\Delta \mathrm{E}_{\mathrm{b}}$ & $5.45 \mathrm{MJ}$ & $5.29 \mathrm{MJ}$ & $5.71 \mathrm{MJ}$ & Blowdown energy \\
\hline$\Delta \mathrm{E}_{\mathrm{t}}$ & $83.7 \mathrm{MJ}$ & $58.2 \mathrm{MJ}$ & $60.4 \mathrm{MJ}$ & Latent and sensible heat \\
\hline$\Delta \mathrm{E}_{\mathrm{r}}$ & $31.9 \mathrm{MJ}$ & $23.2 \mathrm{MJ}$ & $24.1 \mathrm{MJ}$ & Chemical energy from debris oxidation \\
\hline$\Delta \mathrm{E}_{\mathrm{H} 2}$ & $0.0 \mathrm{MJ}$ & $97.7 \mathrm{MJ}$ & $122.0 \mathrm{MJ}$ & Hydrogen combustion \\
\hline$\Psi$ & 0.219 & 0.156 & 0.152 & Heat capacity ratio \\
\hline $\mathrm{U}^{\mathrm{o}}$ & $51.7 \mathrm{MJ}$ & $49.8 \mathrm{MJ}$ & $52.4 \mathrm{MJ}$ & Internal energy of atmosphere \\
\hline $\mathrm{P}^{\mathrm{o}}$ & $0.20 \mathrm{MPa}$ & $0.19 \mathrm{MPa}$ & $0.20 \mathrm{MPa}$ & Initial pressure of atmosphere \\
\hline$\Delta \mathrm{P}$ & $0.384 \mathrm{MPa}$ & $0.608 \mathrm{MPa}$ & $0.704 \mathrm{MPa}$ & Calculated pressure rise \\
\hline$\eta$ & $26 \%$ & $40 \%$ & $37.2 \%$ & DCH efficiency \\
\hline
\end{tabular}

Table 6

Summary of the Results of the IET-1, IET-3, and IET-4 Experiments

\begin{tabular}{|c|c|c|c|}
\hline 1. & IET-1 & IET-3 & IET-4 \\
\hline Driving pressure at plug failure (MPa) & 7.1 & 6.1 & 6.7 \\
\hline Moles of $\mathrm{H}_{2} \mathrm{O}$ driving gas (g.moles) & 440 & 456 & 583 \\
\hline Cavity water $(\mathrm{g} \cdot \mathrm{moles})$ & 193 & 193 & 193 \\
\hline Ablated hole diameter $(\mathrm{cm})$ & 4.04 & 4.53 & 4.22 \\
\hline Total debris dispersed into Surtsey (kg) & 43.0 & 34.3 & 40.7 \\
\hline$\triangle \mathrm{P}$ due to the HPME (MPa) & 0.098 & 0.246 & 0.262 \\
\hline Moles of $\mathrm{H}_{2}$ produced ( $\left.\mathrm{g} \cdot \mathrm{moles}\right)$ & 223 & 223 & 297 \\
\hline Moles of $\mathrm{H}_{2}$ burned ( $\mathrm{g} \cdot$ moles) & $\approx 0$ & 186 & 236 \\
\hline
\end{tabular}




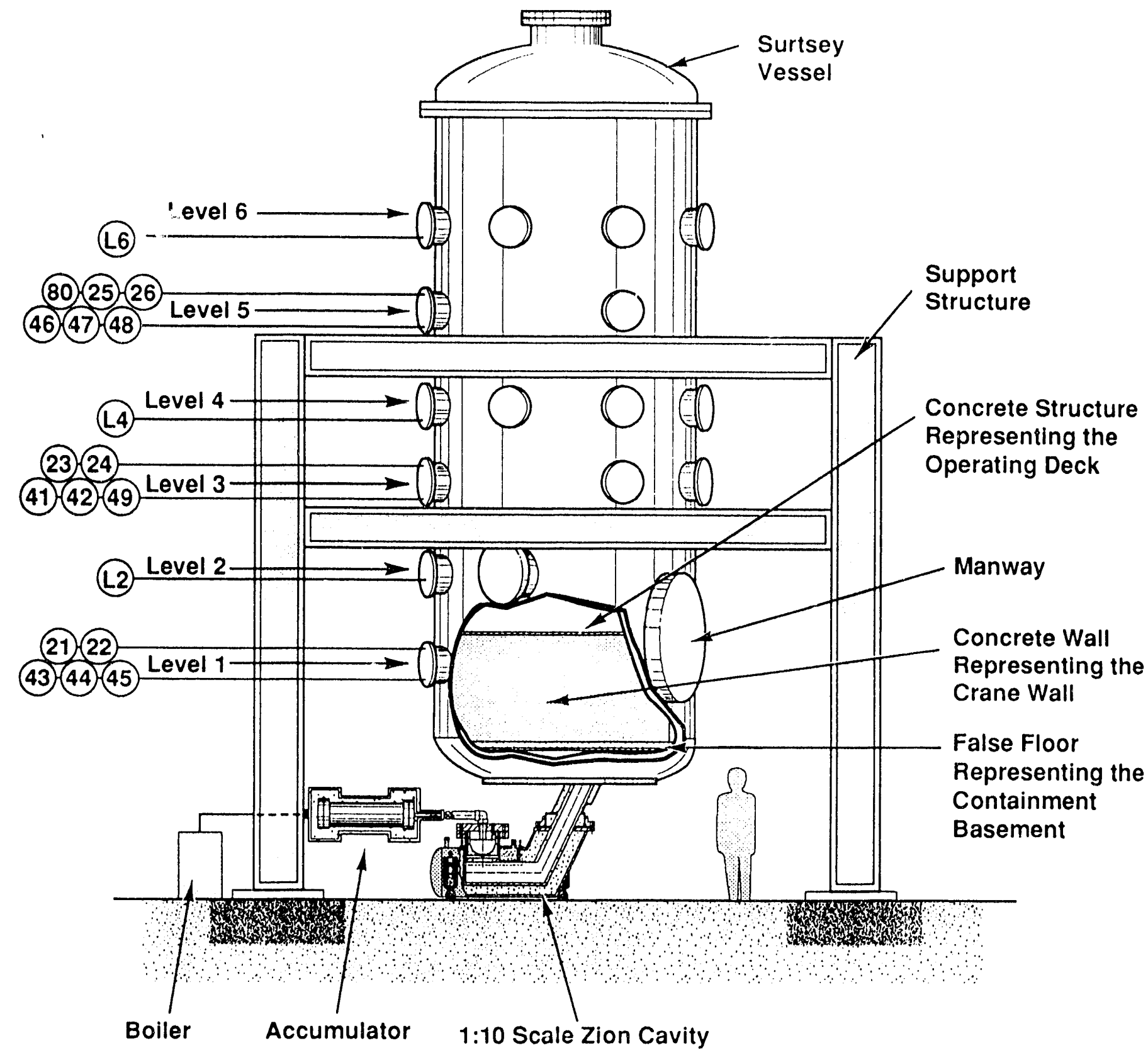

Note: All pressure transducers have individual penetrations.

Figure 1. Surtsey vessel, high-pressure melt ejection system, and subcompartment structures used in the IET-4 experiment. The figure also shows instrumentation location by channel number. 
(요

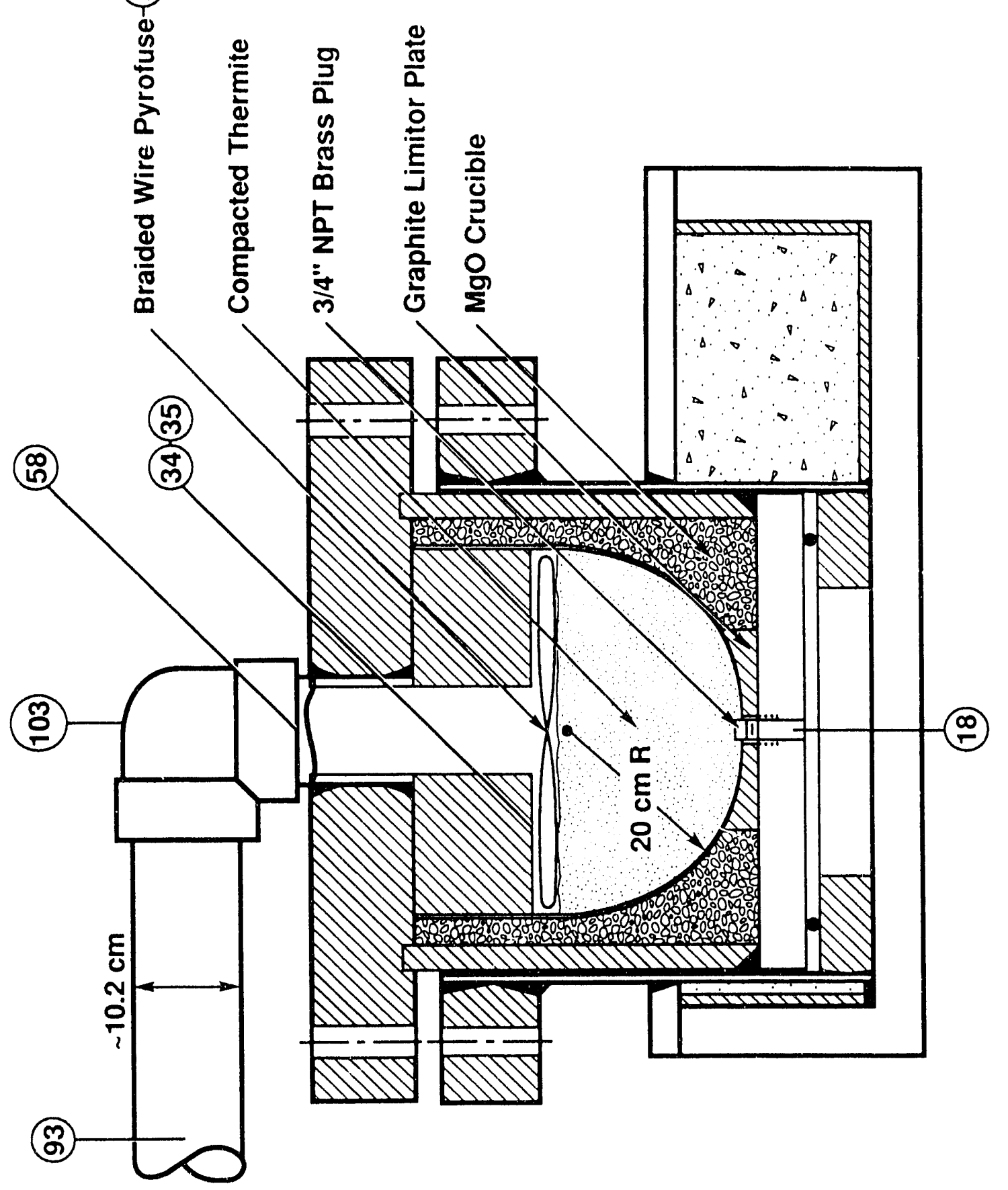

总

峞

폴

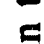

马্

를

용

뭉

它

盛 


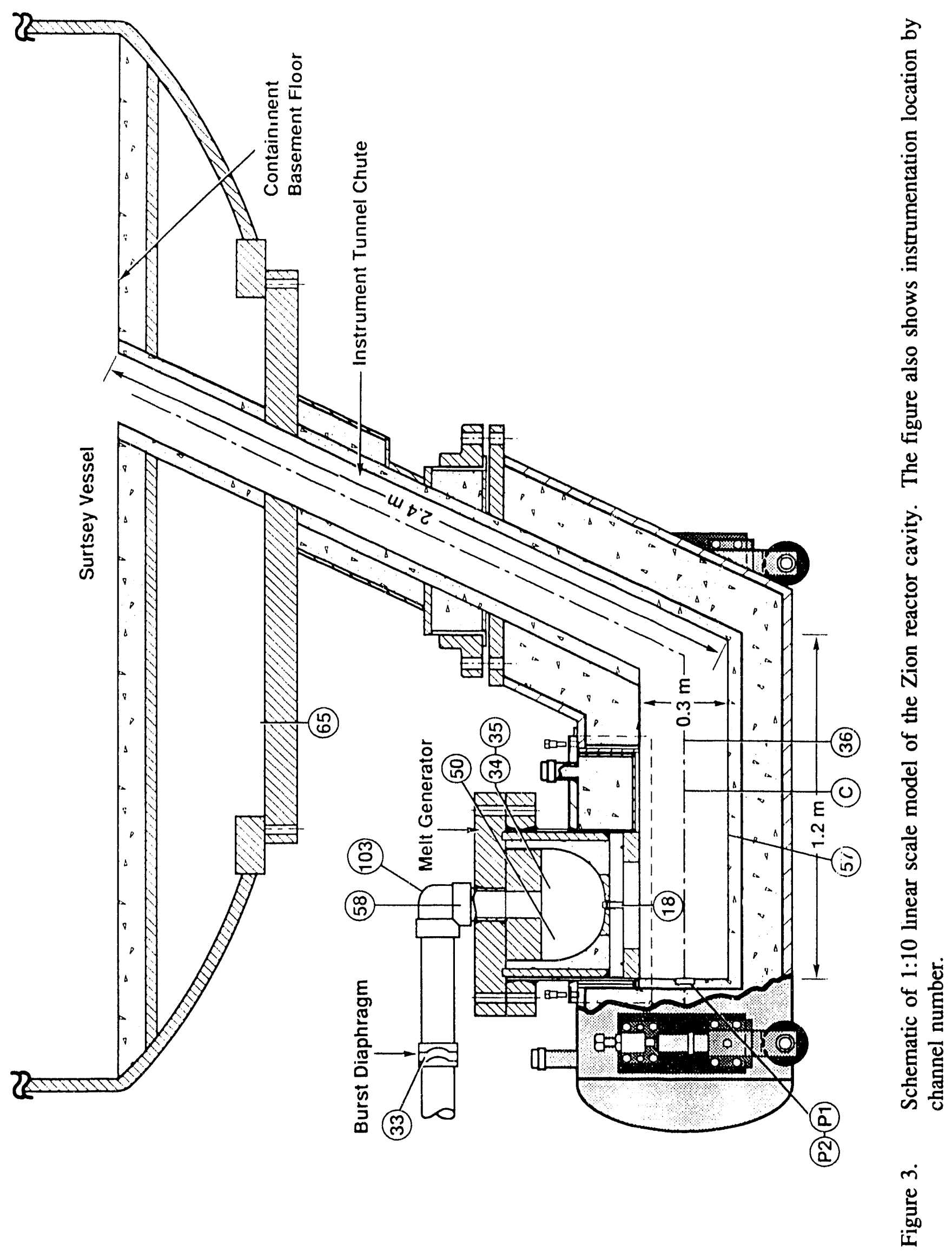




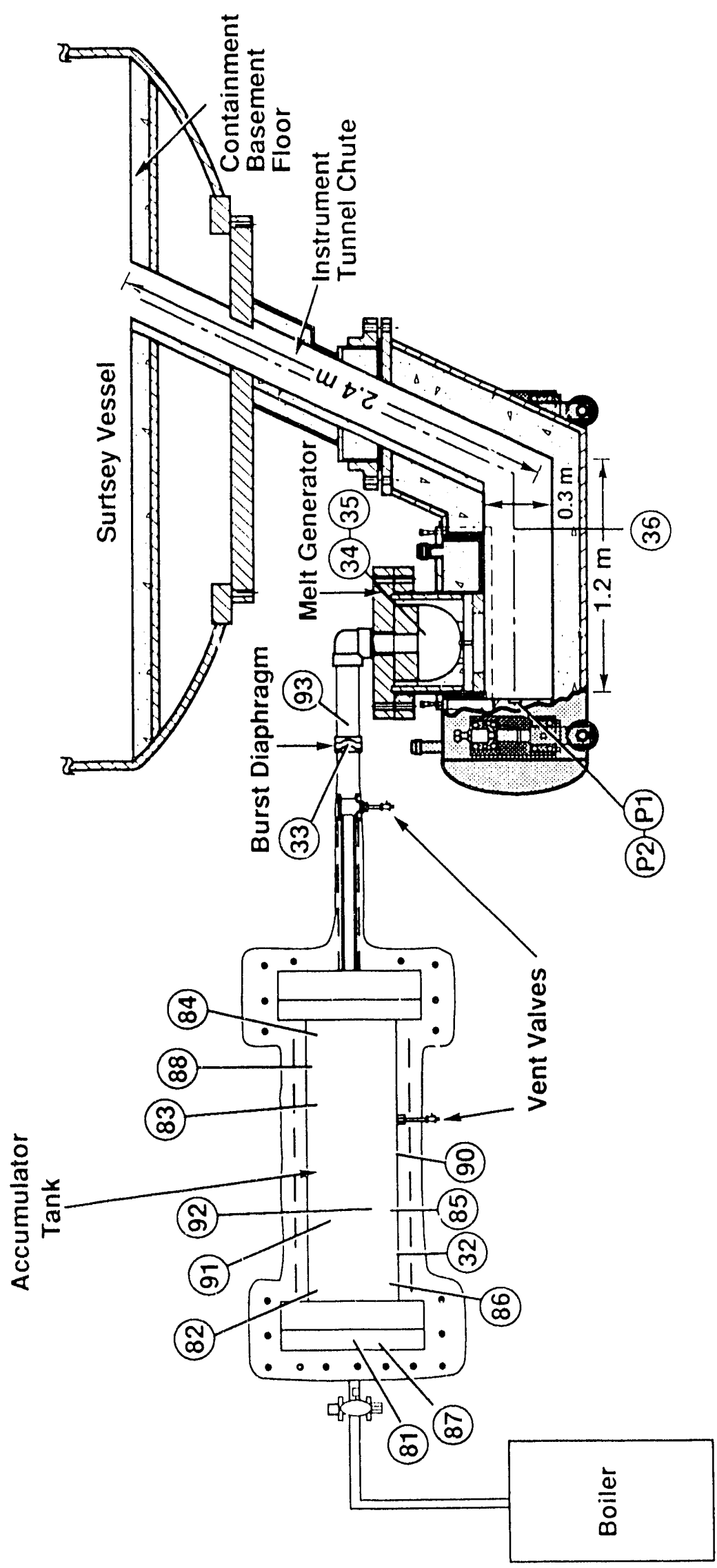

告

흘

気

ฮี

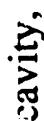

苛

흠

芫

立完

음

텽

新

녹음

氙

¿

을

它

王.巨

守 


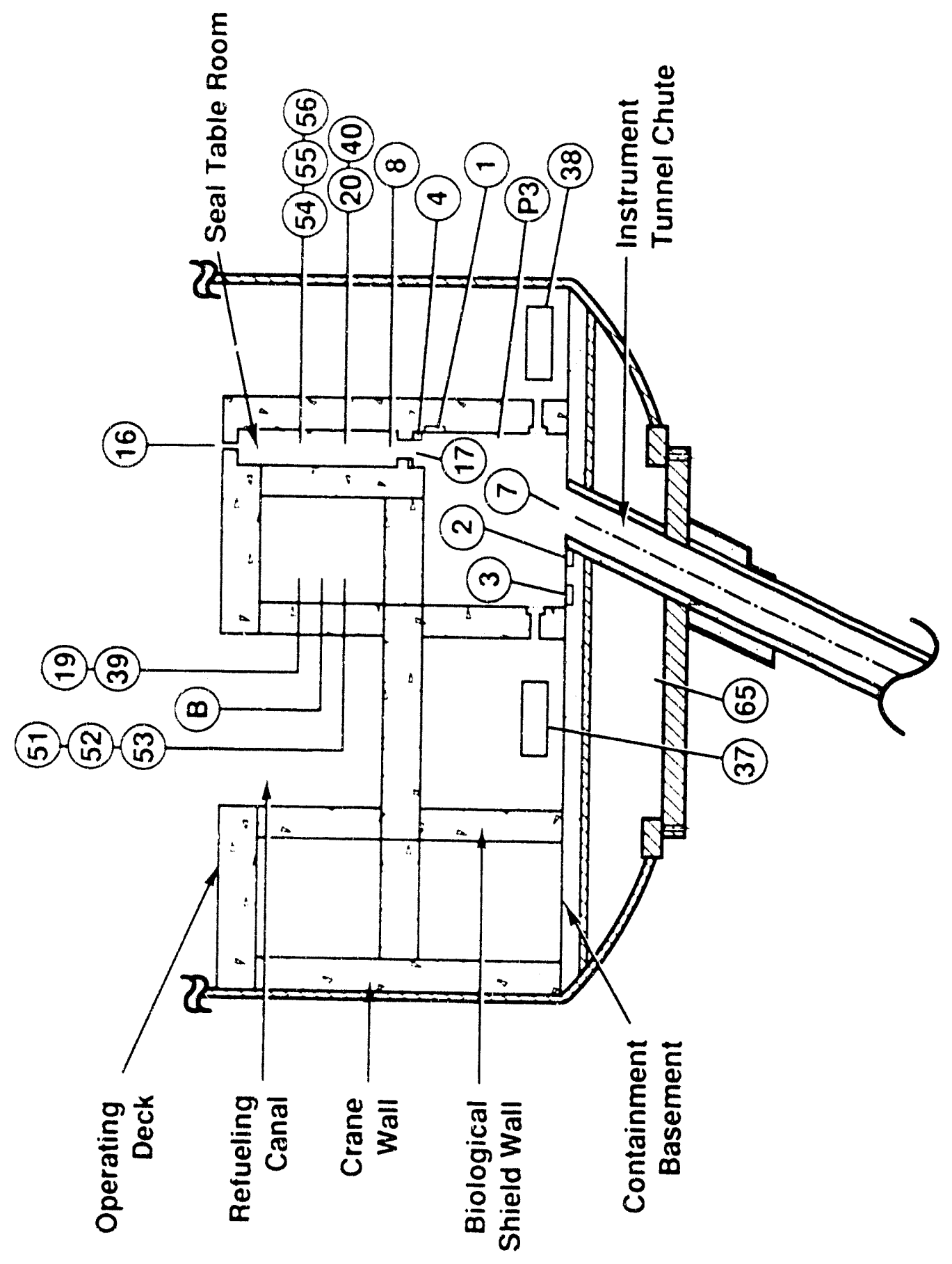

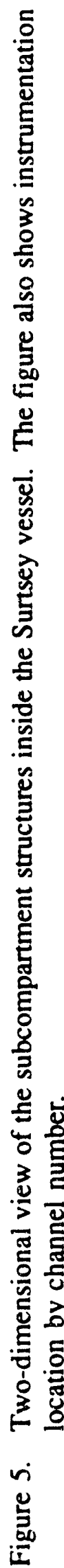




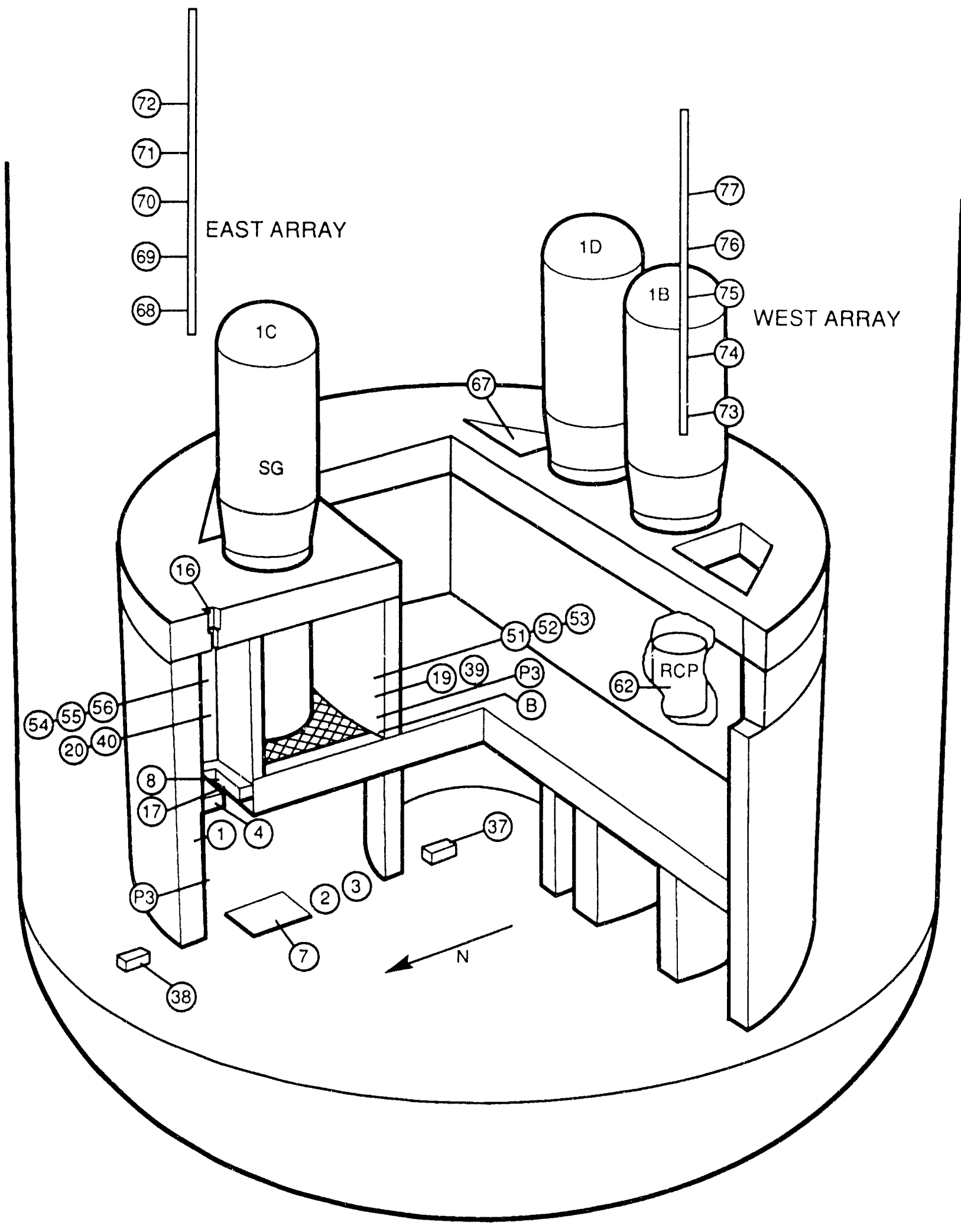

Figure 6. Isometric view of the subcompartment structures inside the Surtsey vessel. The figure also shows instrumentation location by channei number. 


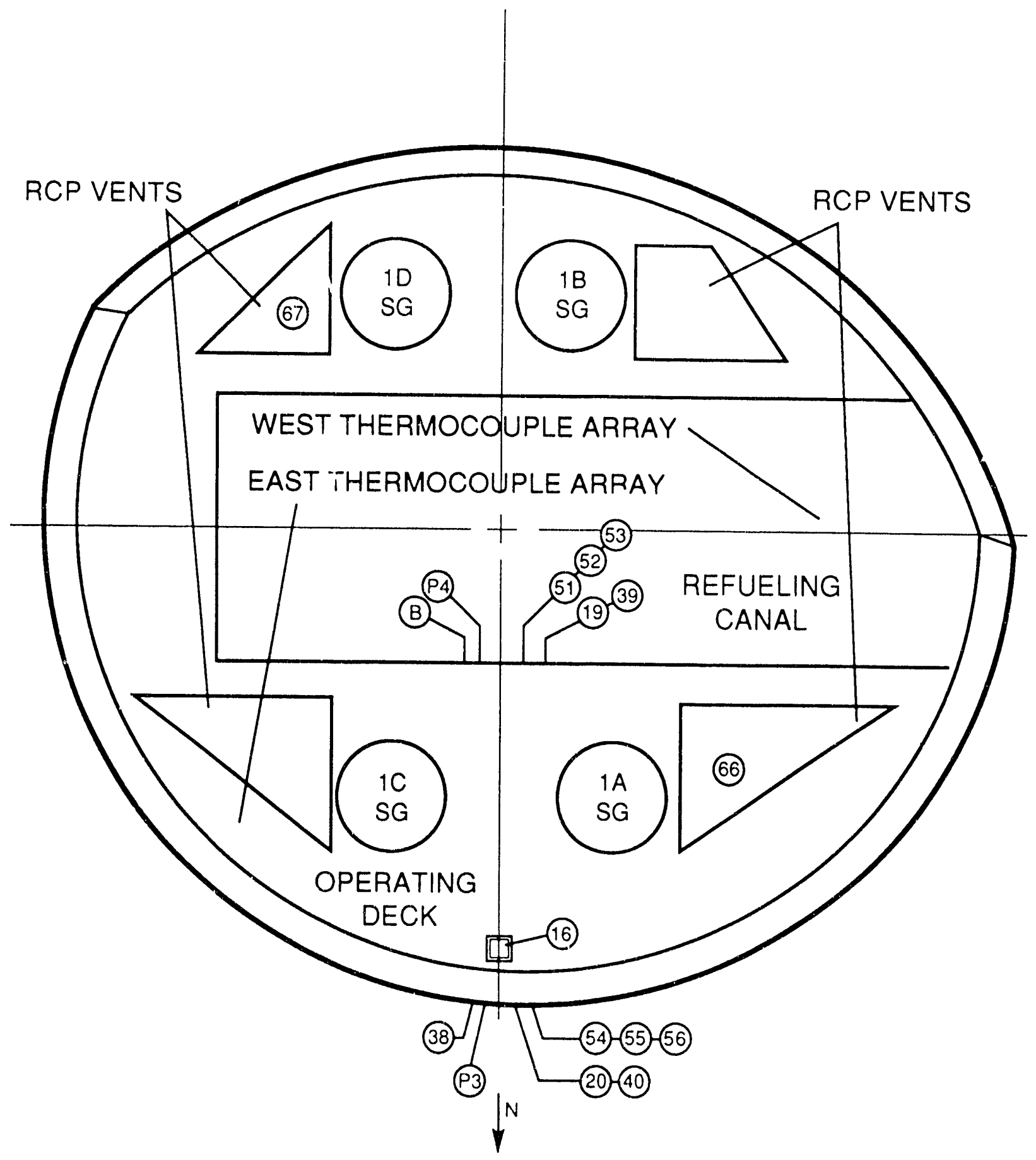

Figure 7. Top view of structures inside the Surtsey vessel. The figure also shows instrumentation location by channel number. 


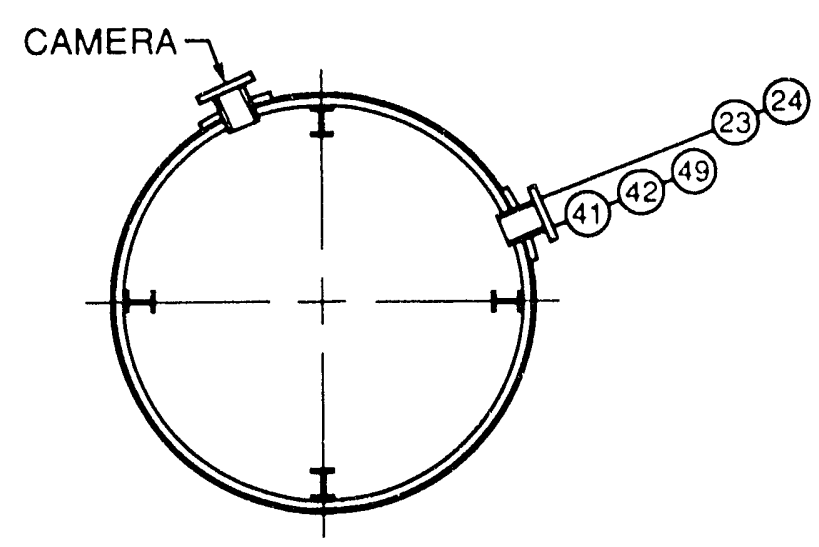

LEVEL 3
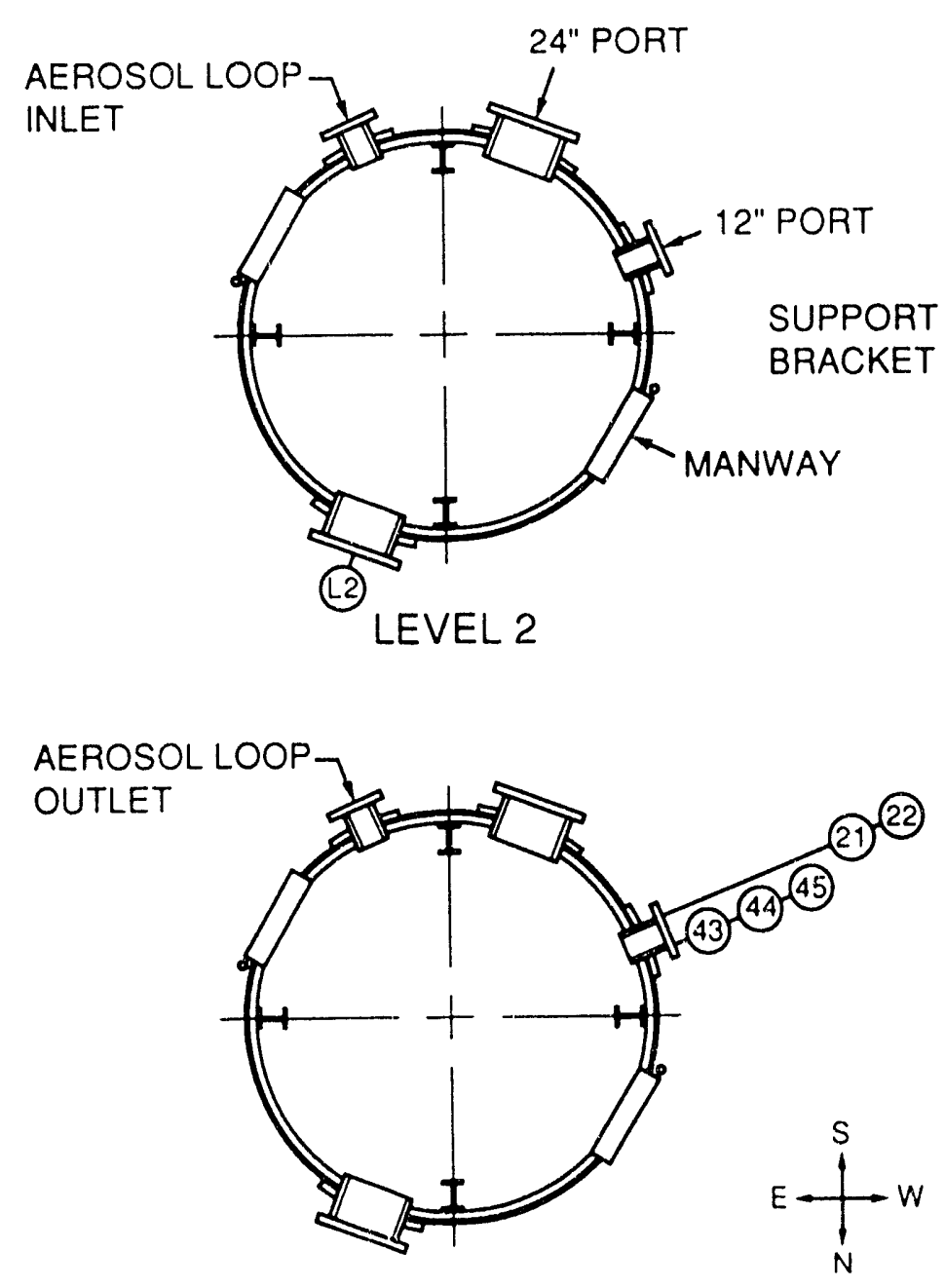

LEVEL 1

LEVEL 1

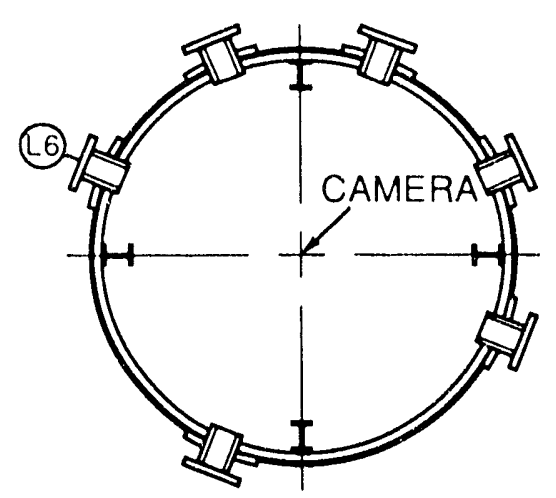

LEVEL 6

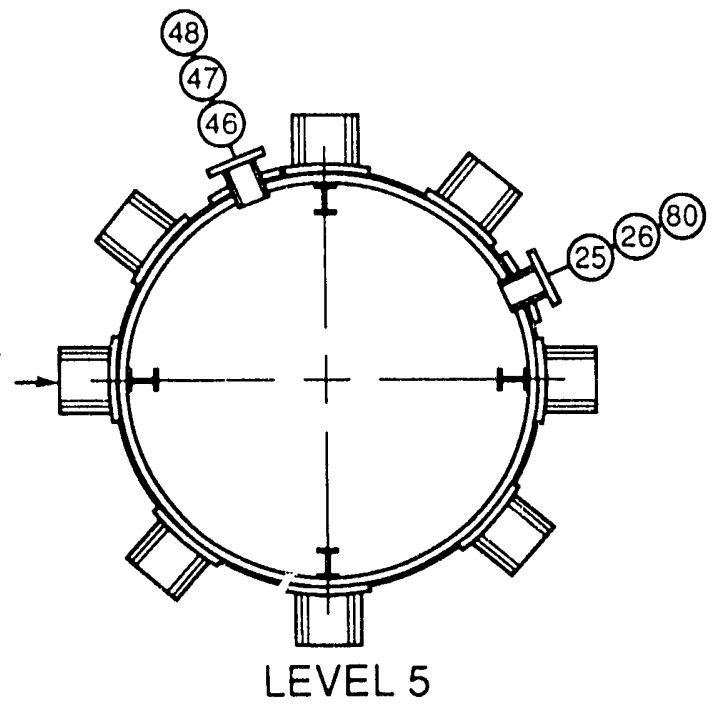

(48)

LEV 5

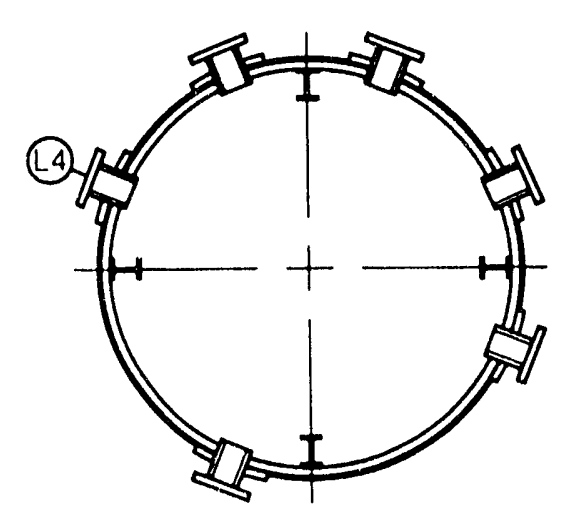

LEVEL 4

Figure 8. Top view of the Surtsey vessel showing instrumentation ports. The figure also shows instrumentation location by channel number. 


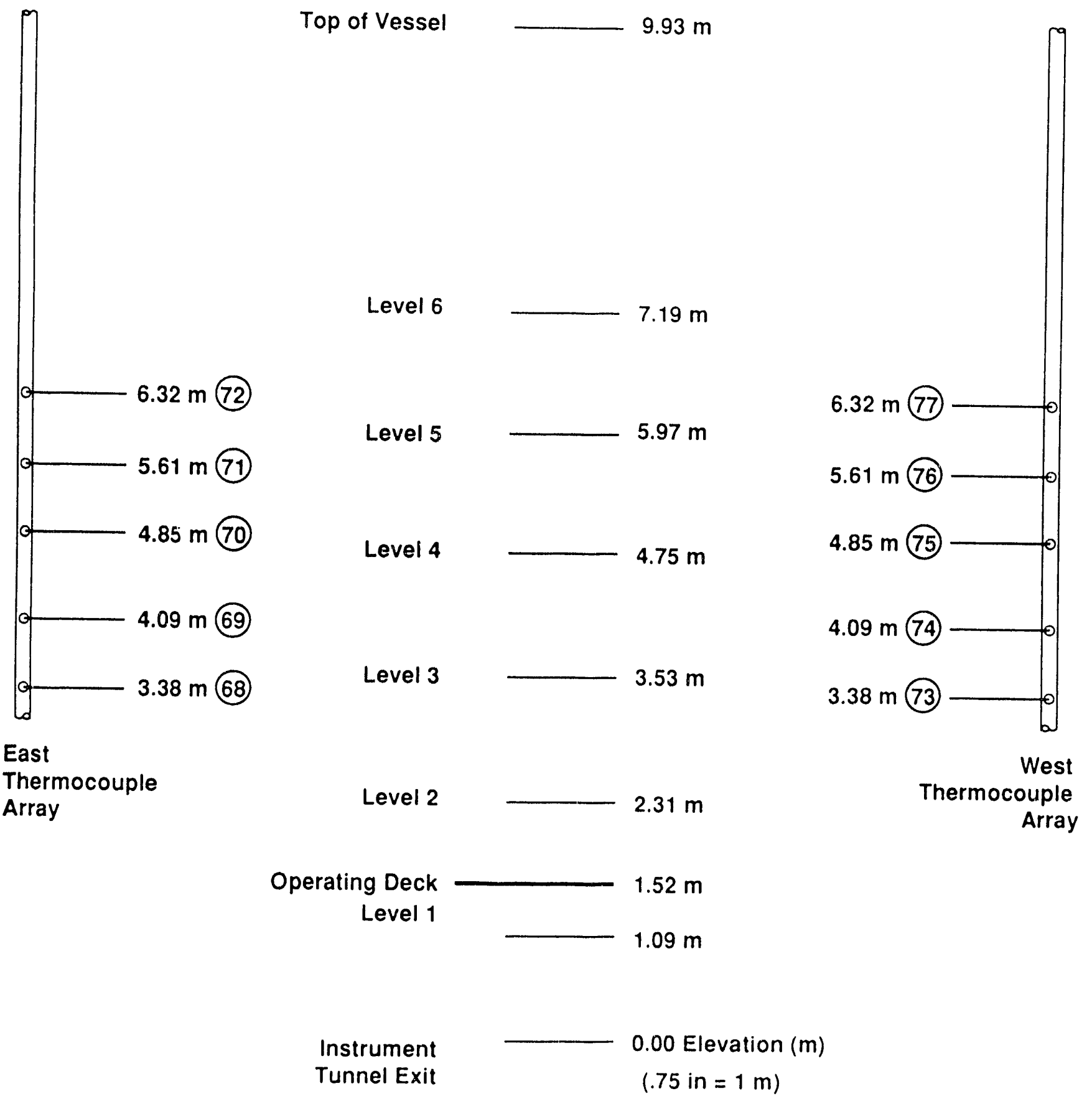

Figure 9. Location of Surtsey vessel bulk gas temperature thermocouple arrays. The figure also shows instrumentation location by channel number. 


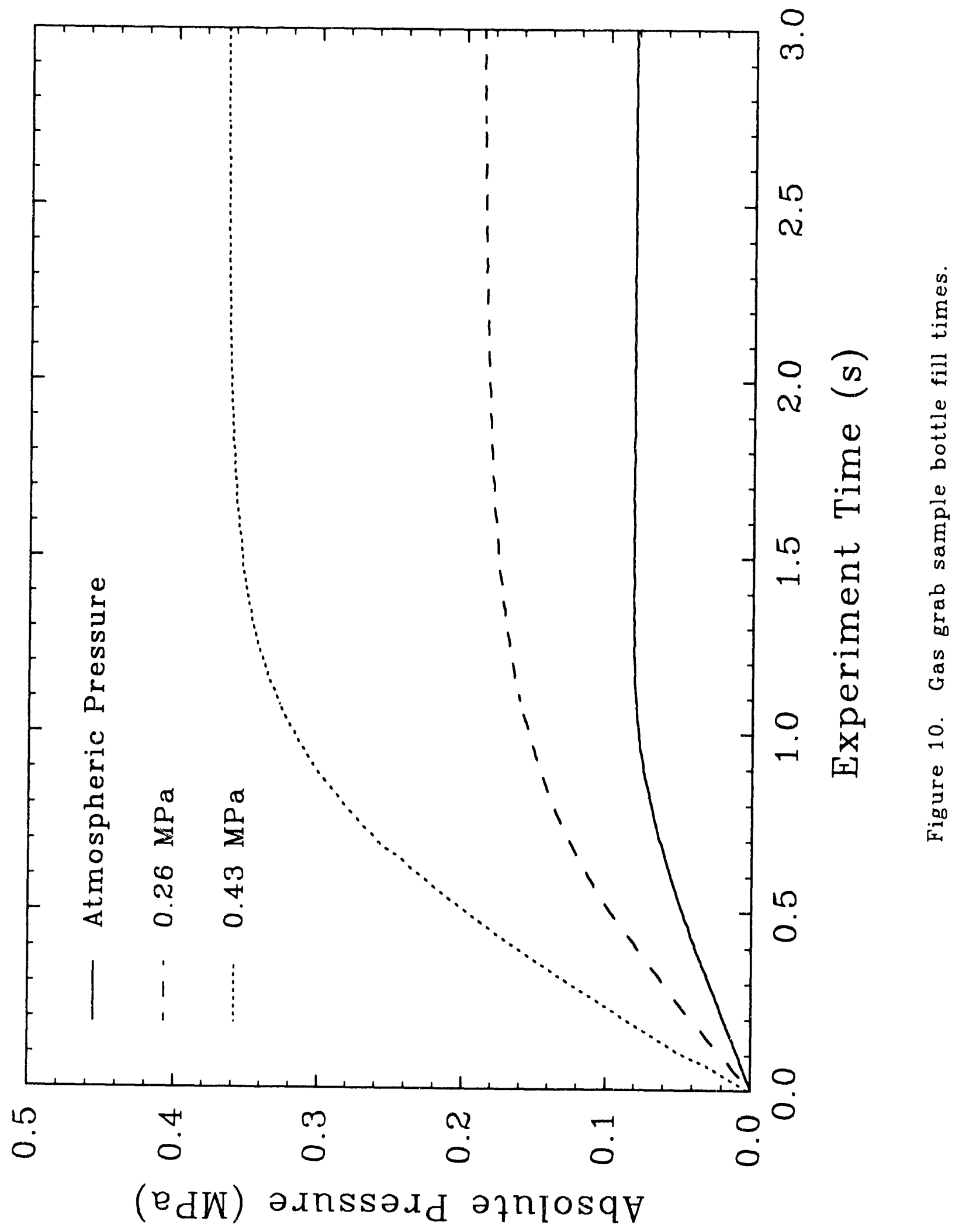




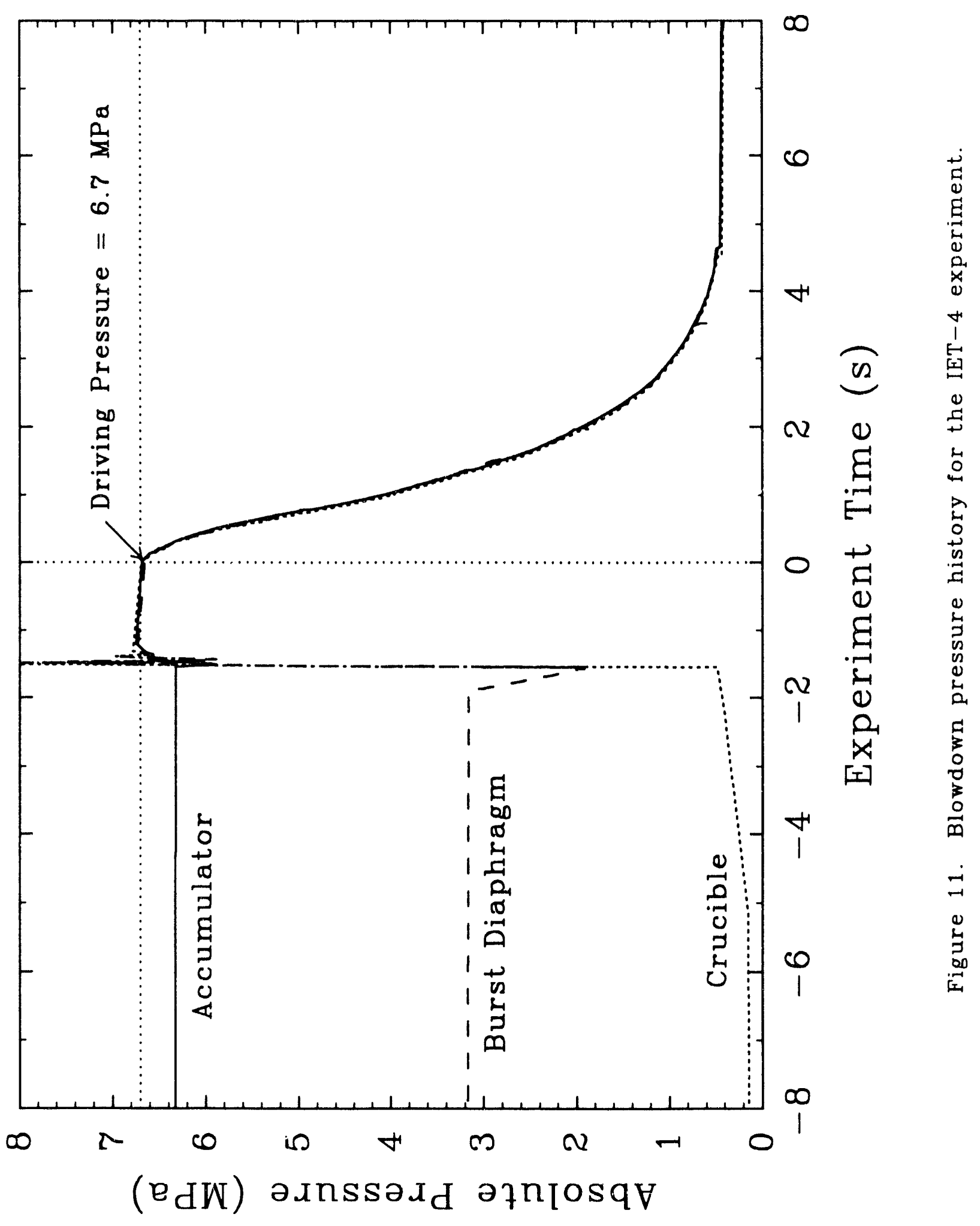




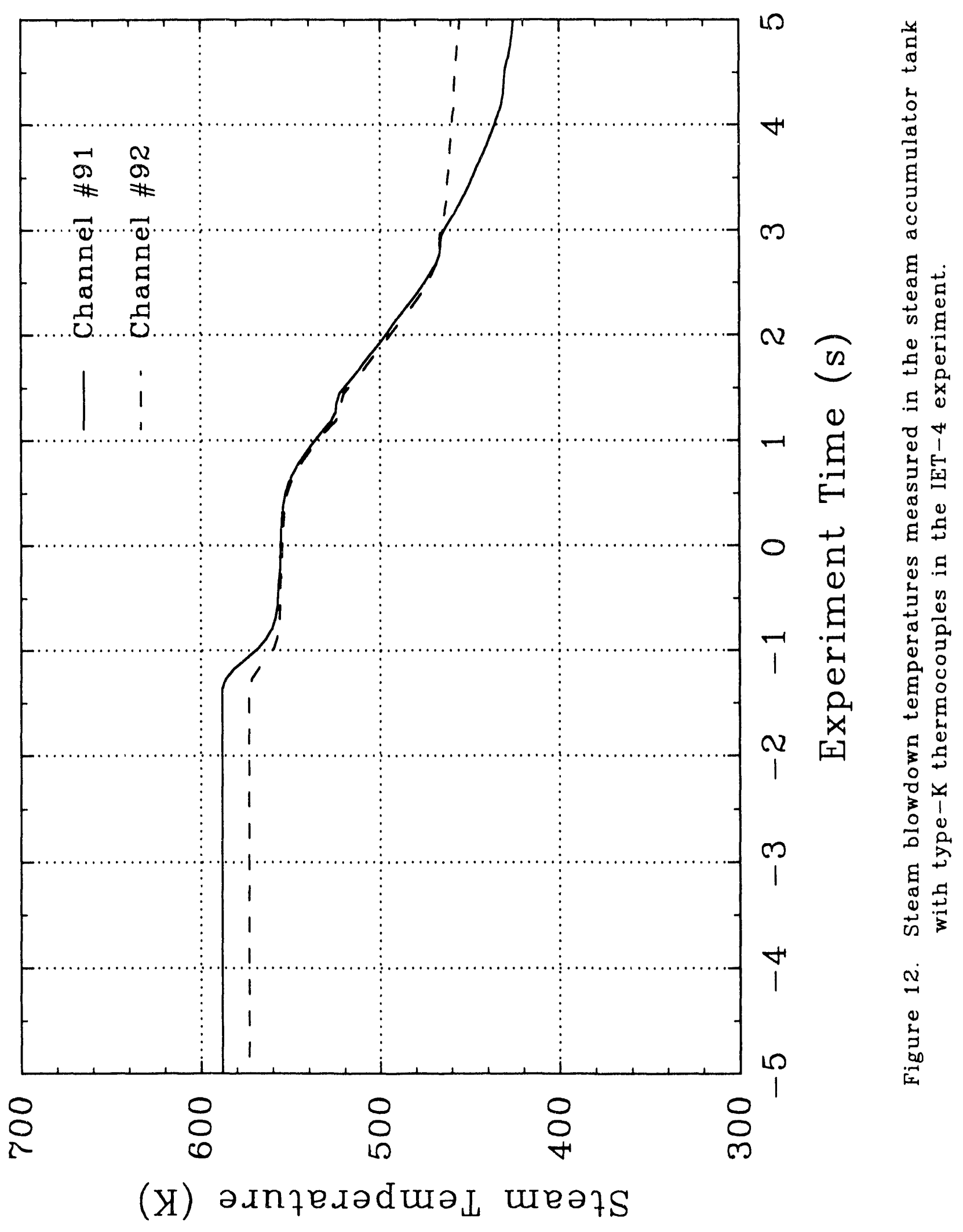




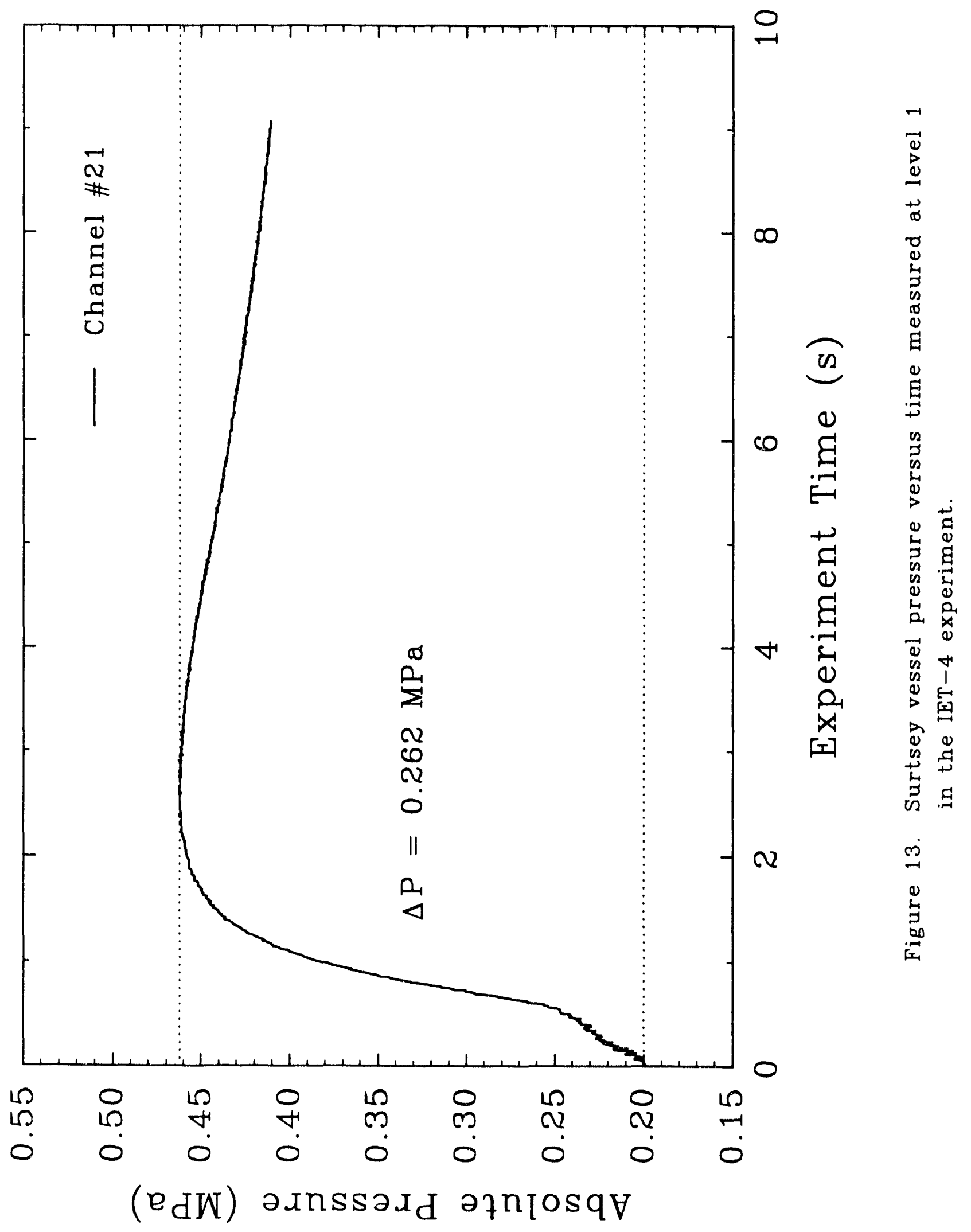




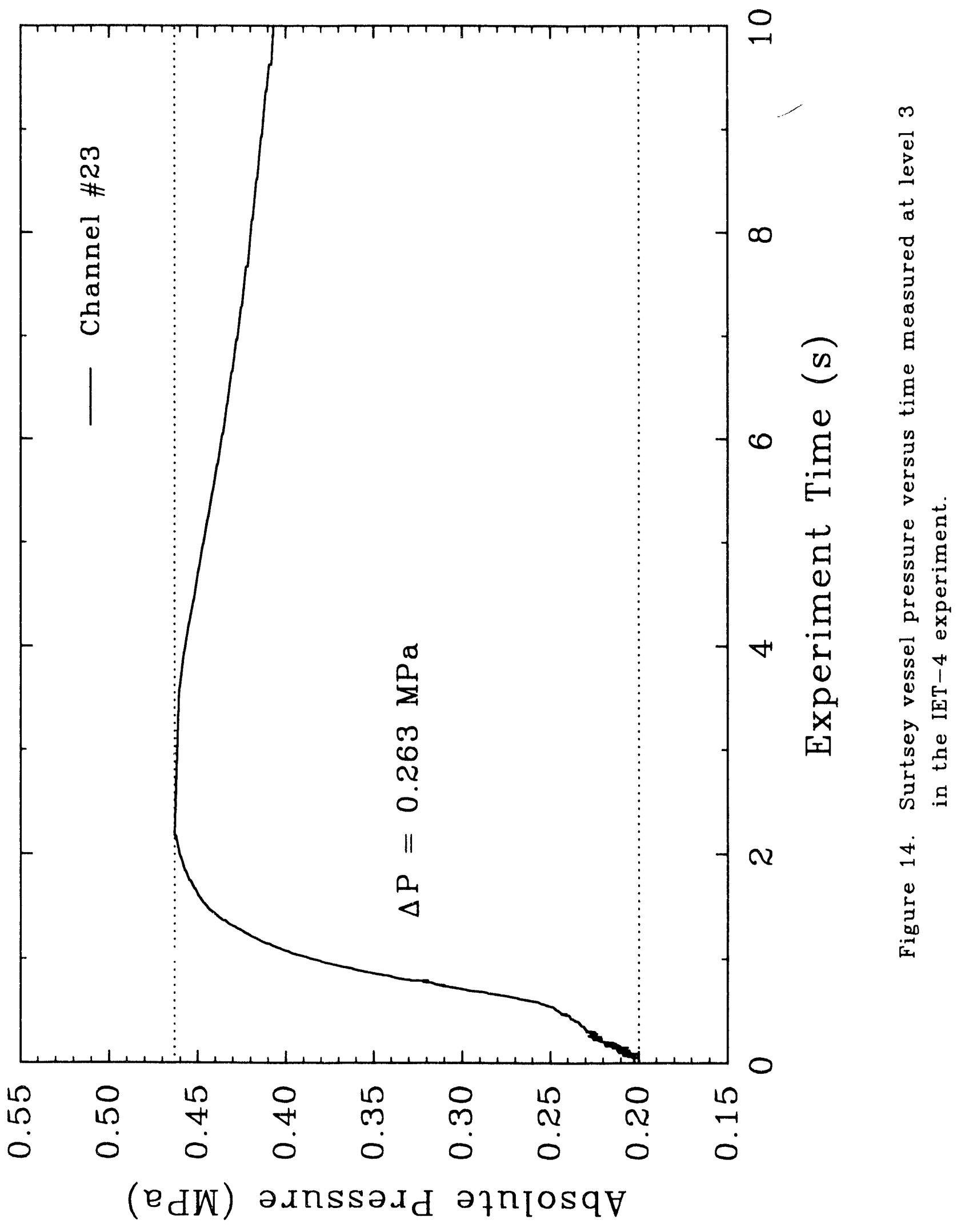




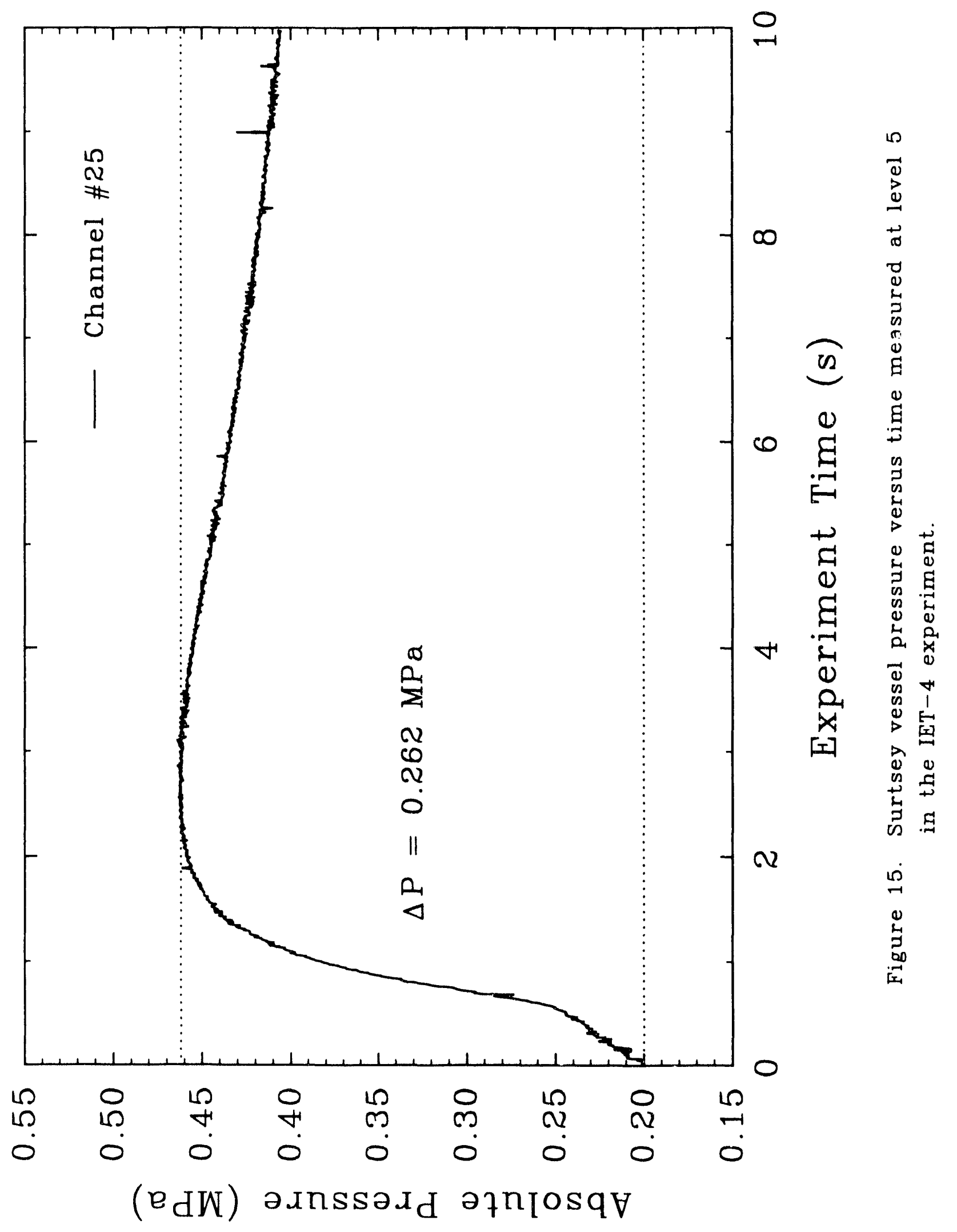




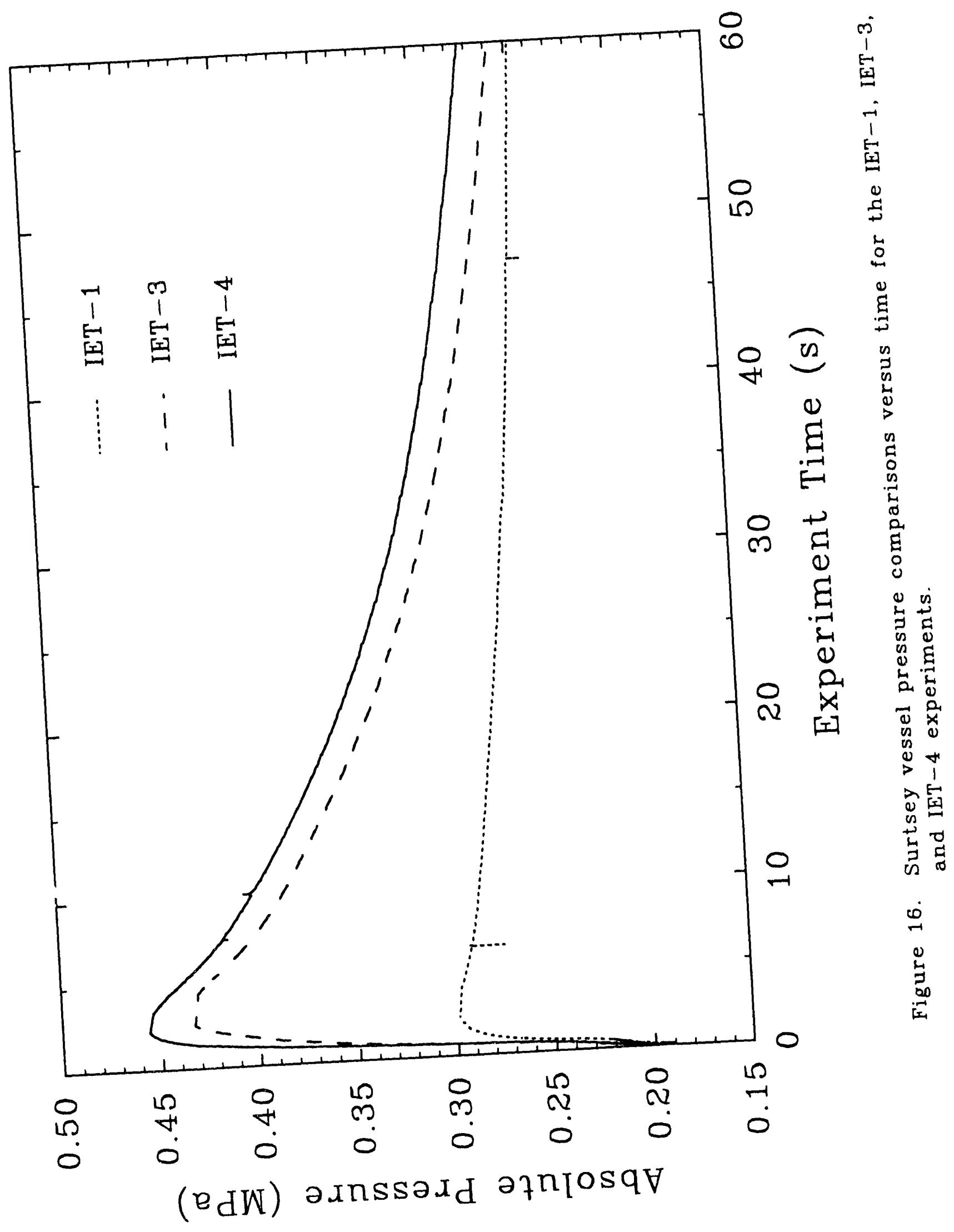




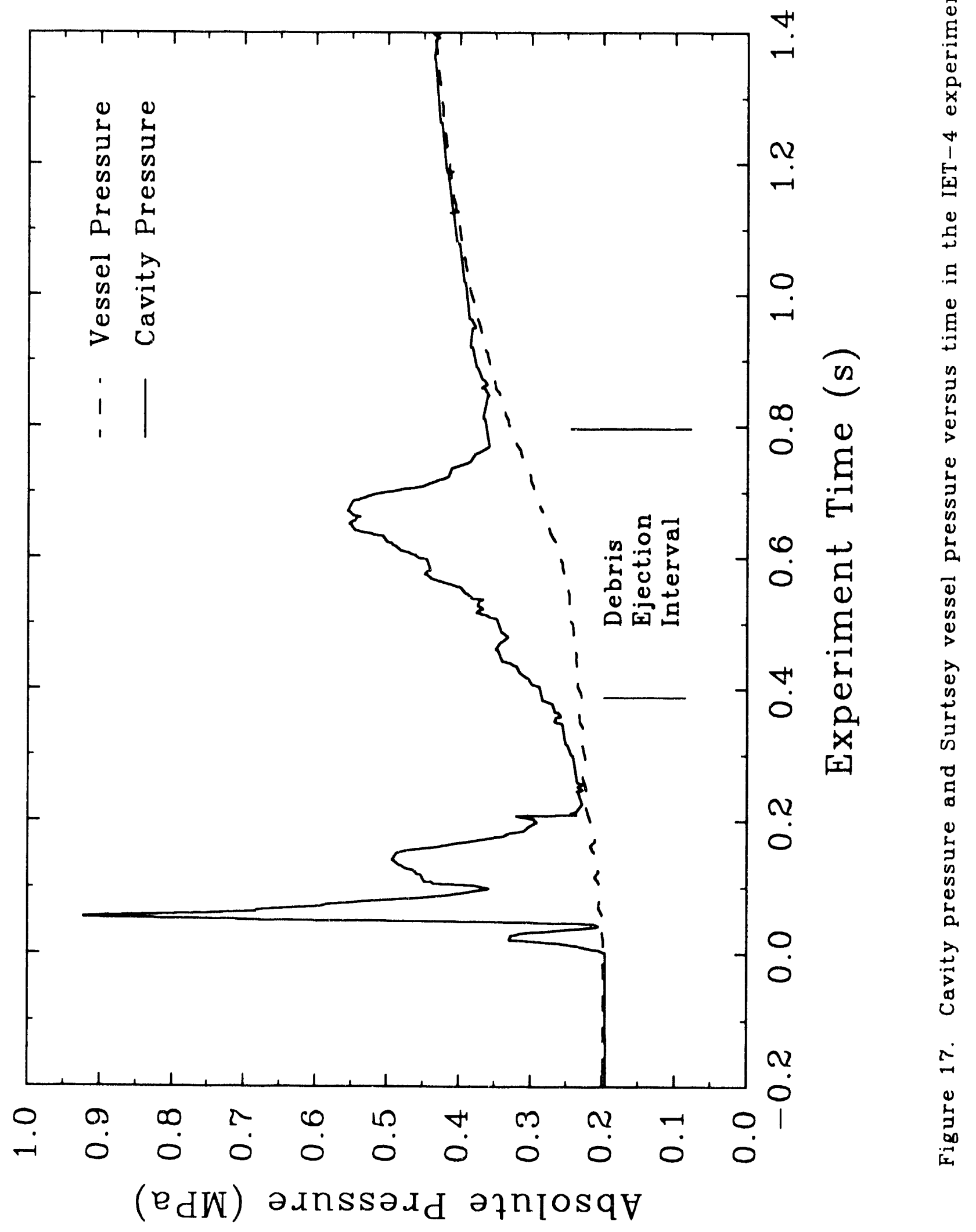




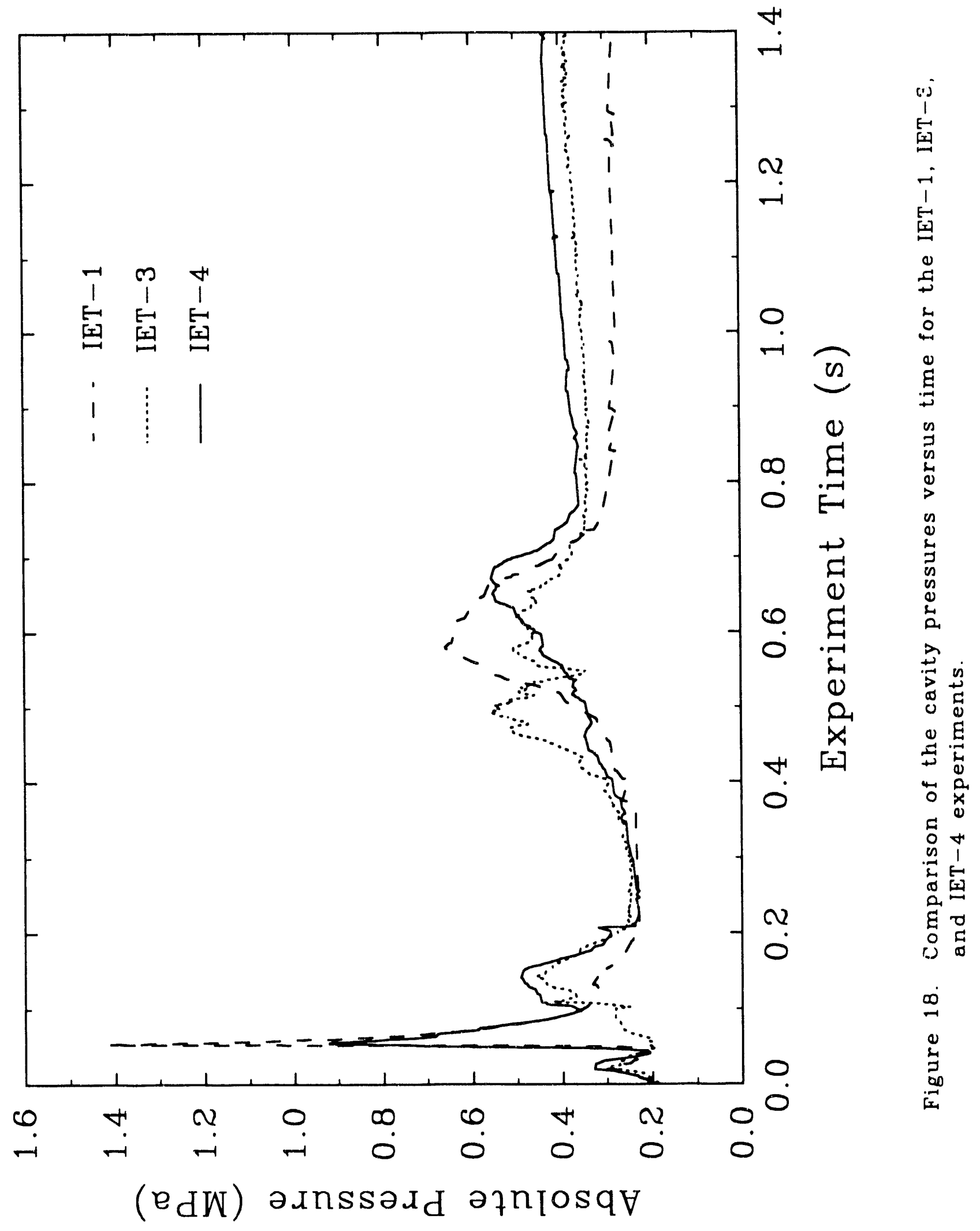




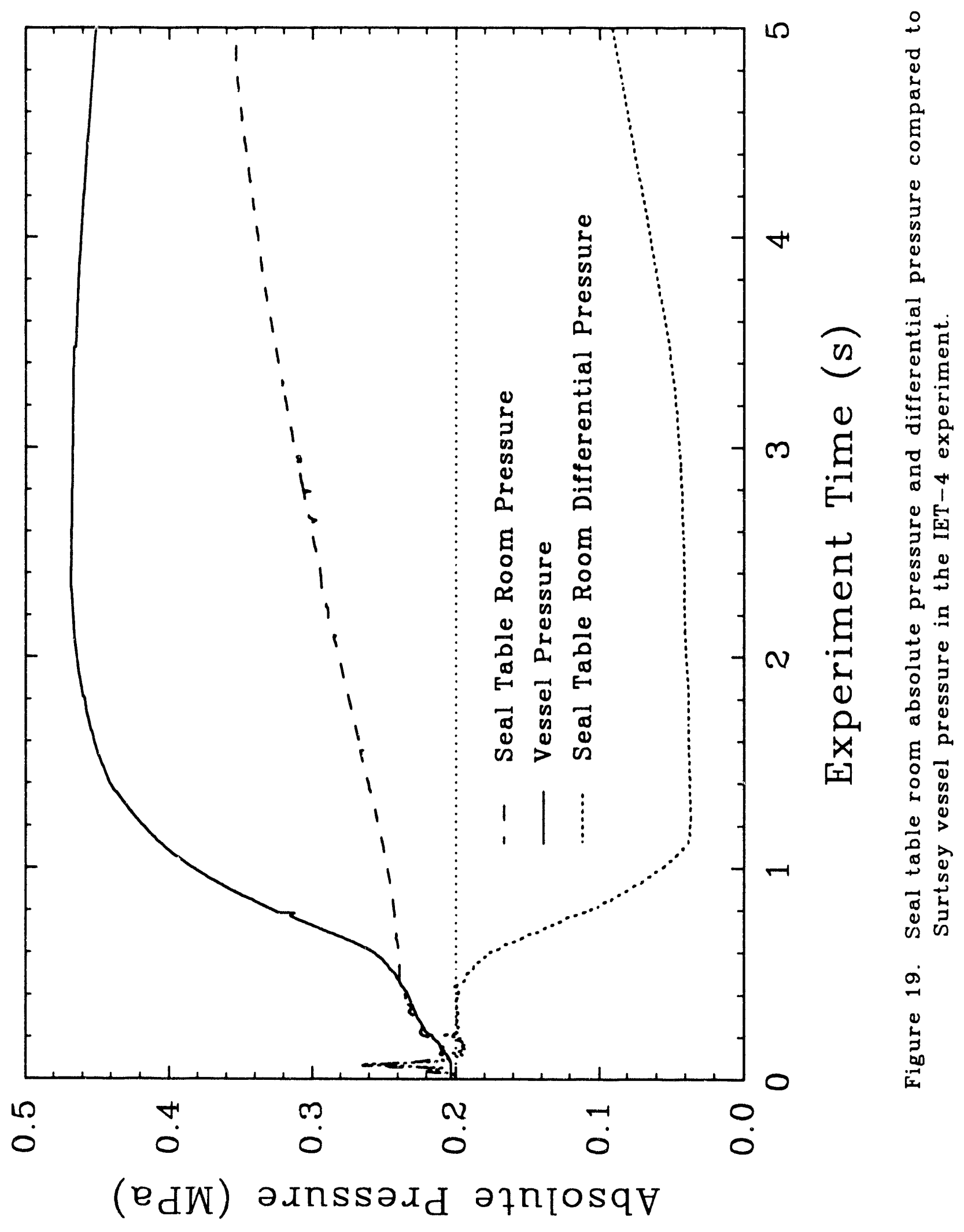




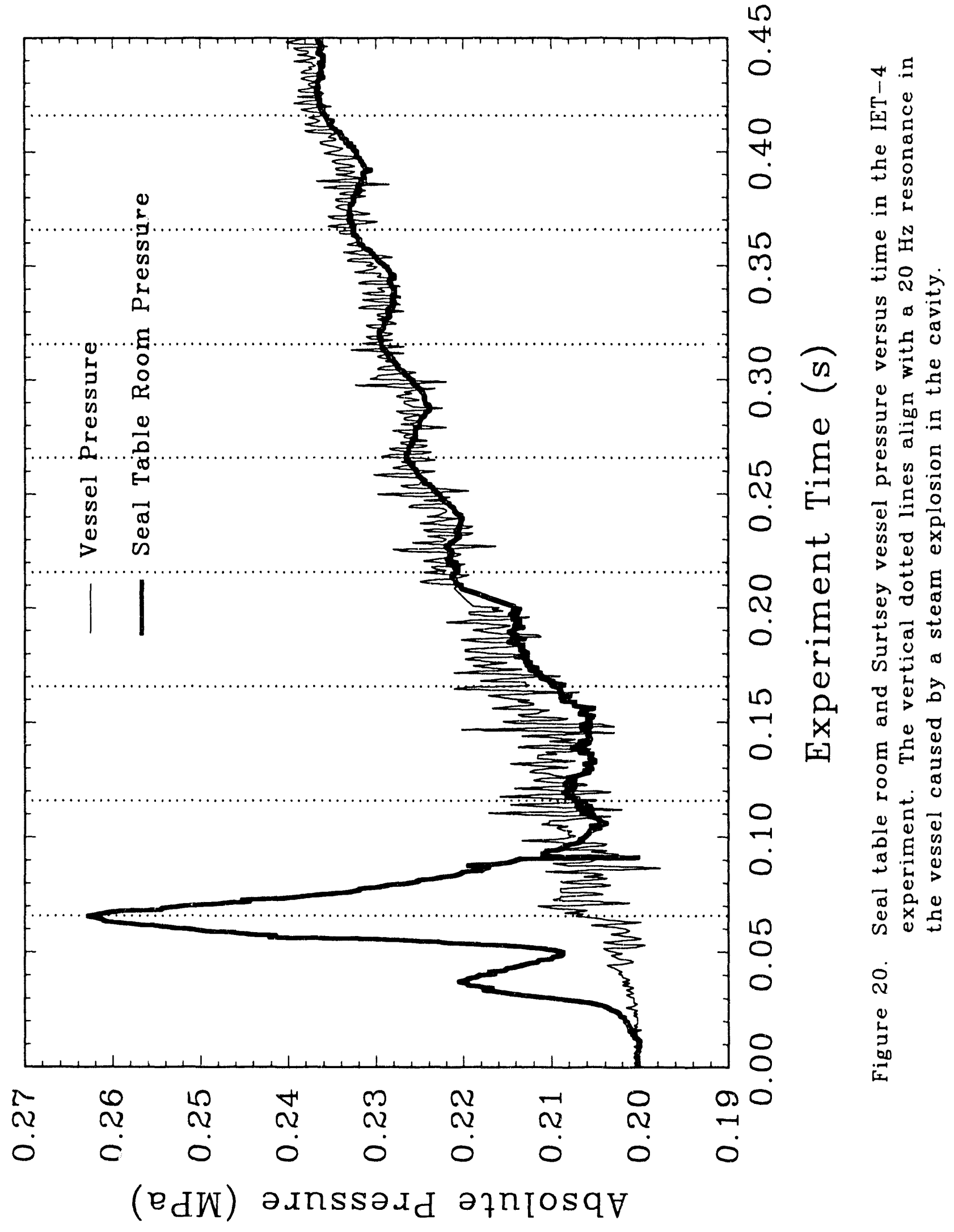




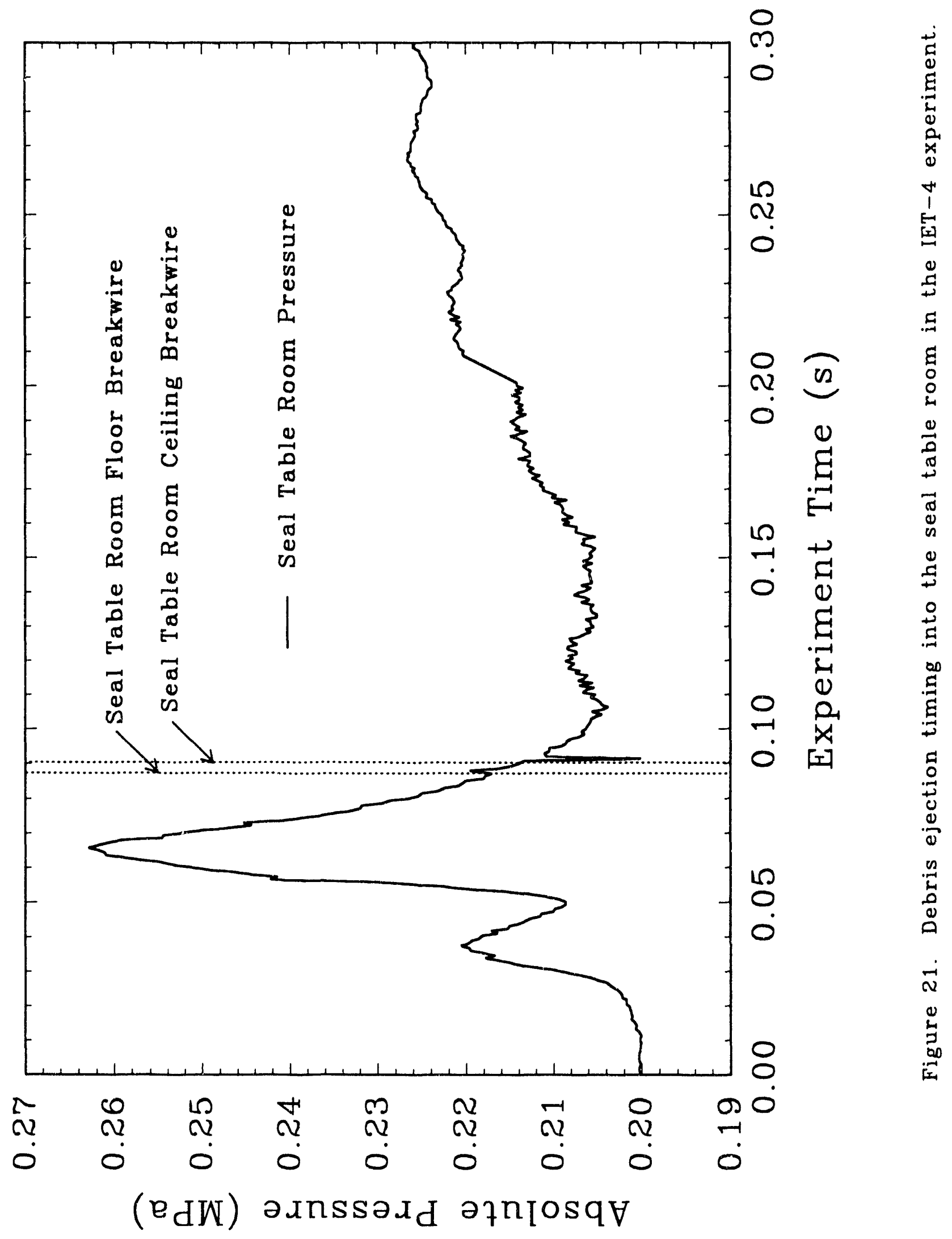




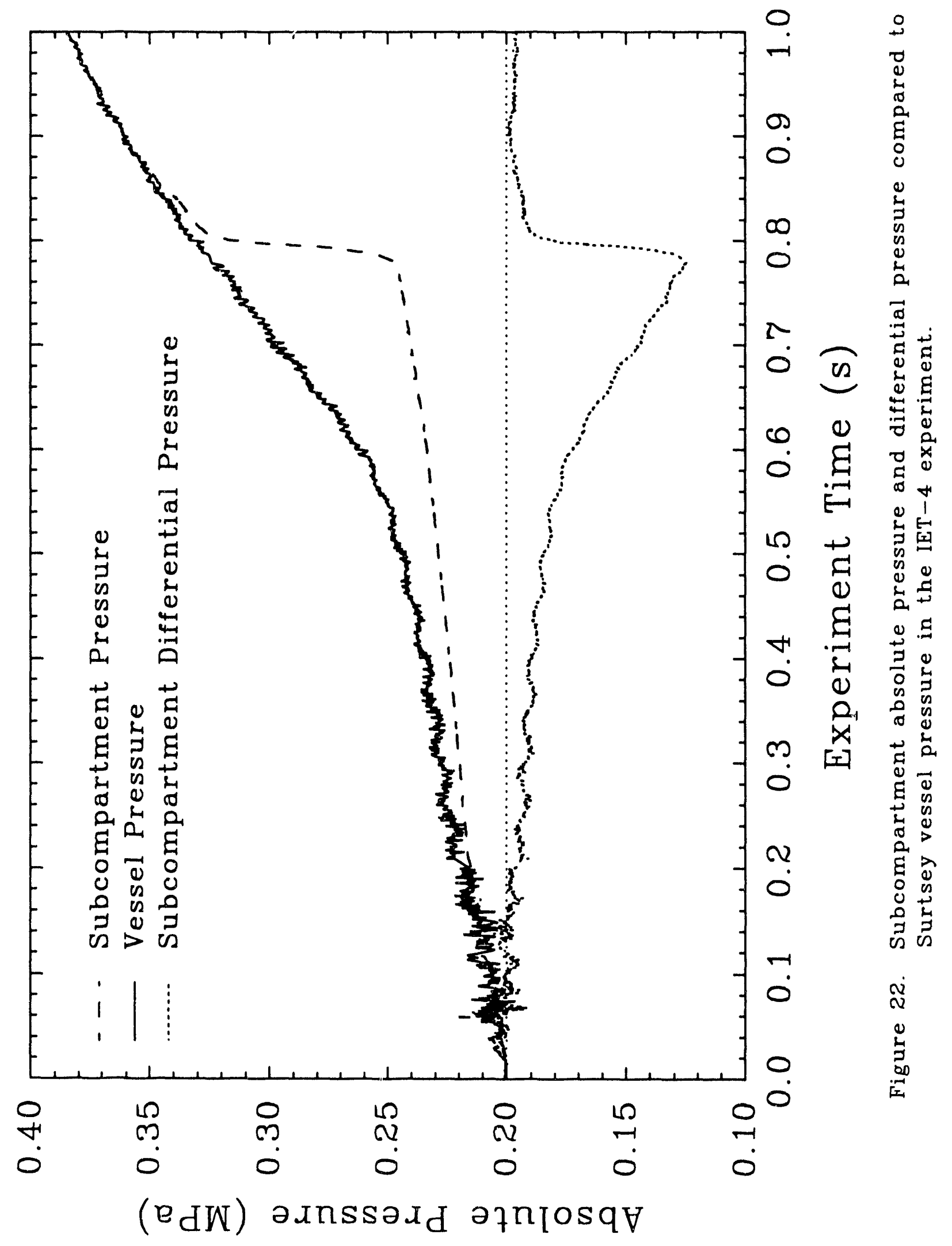




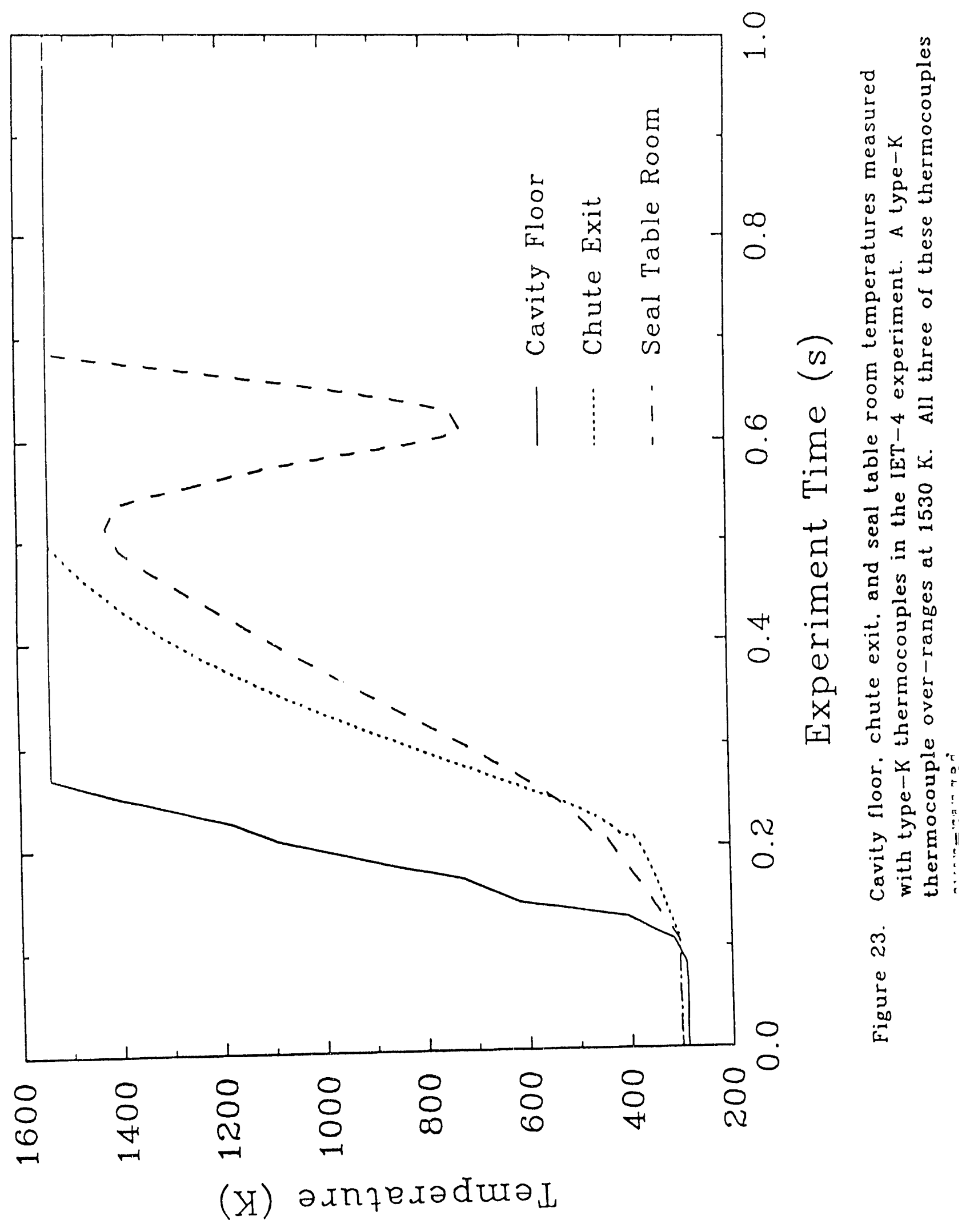




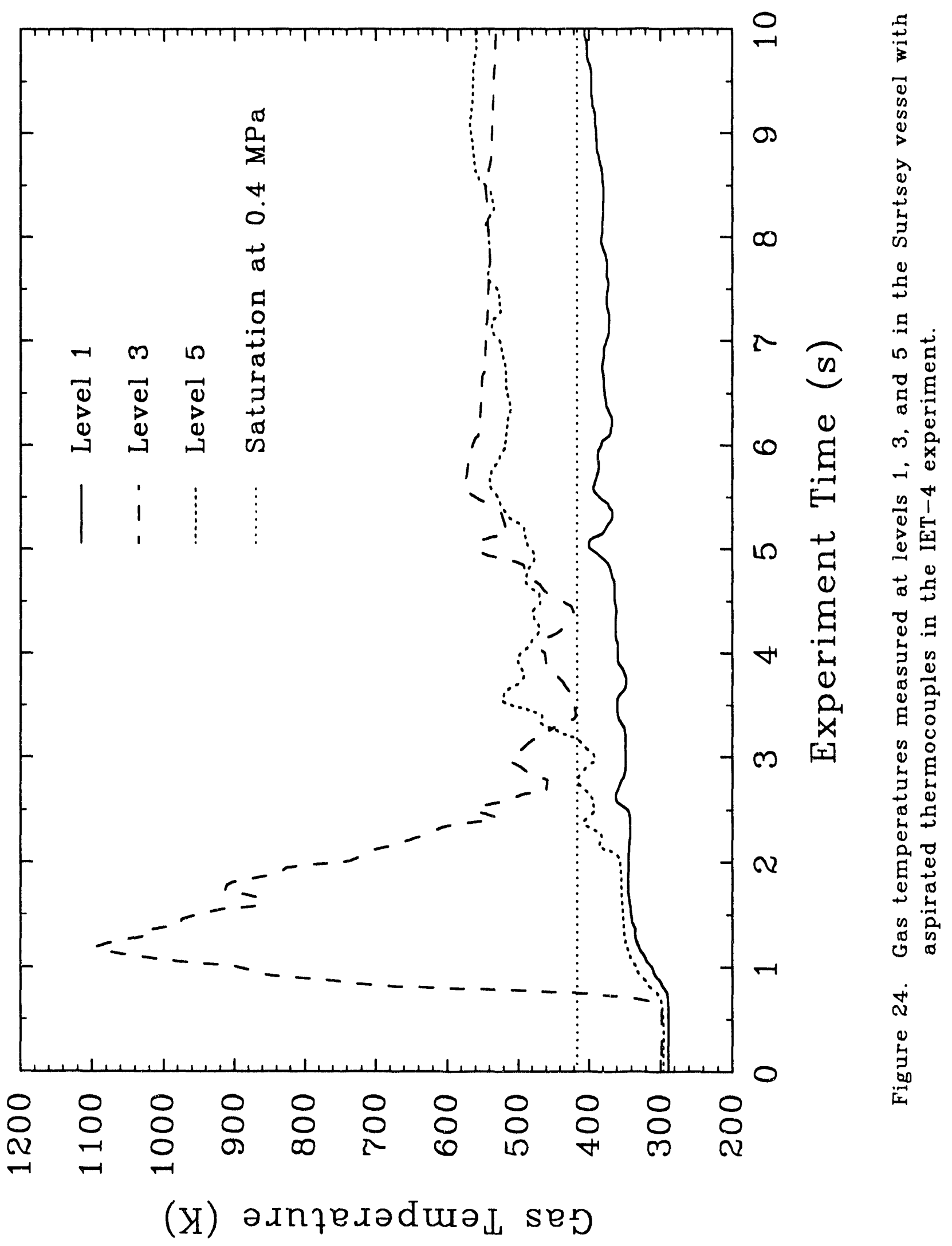




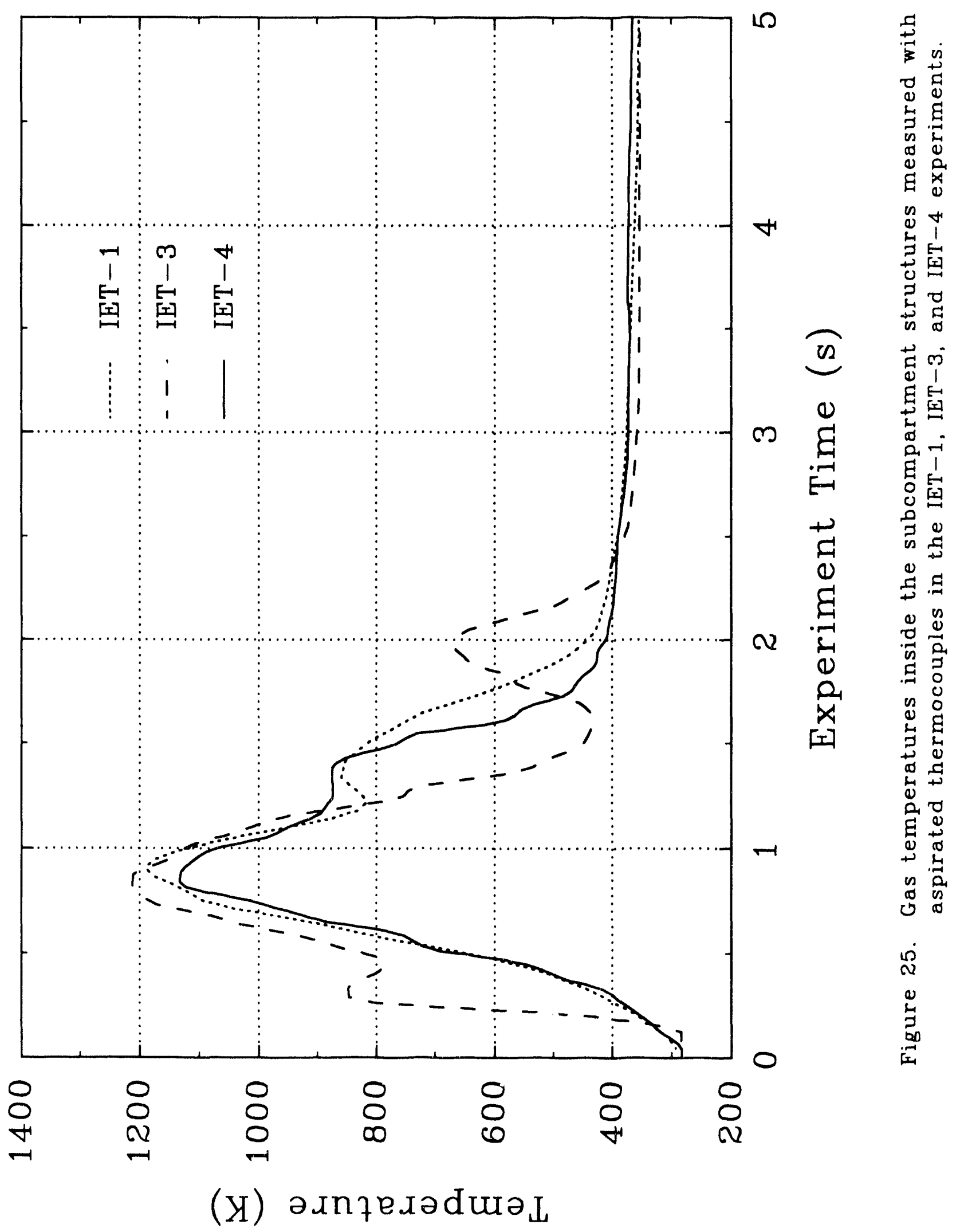




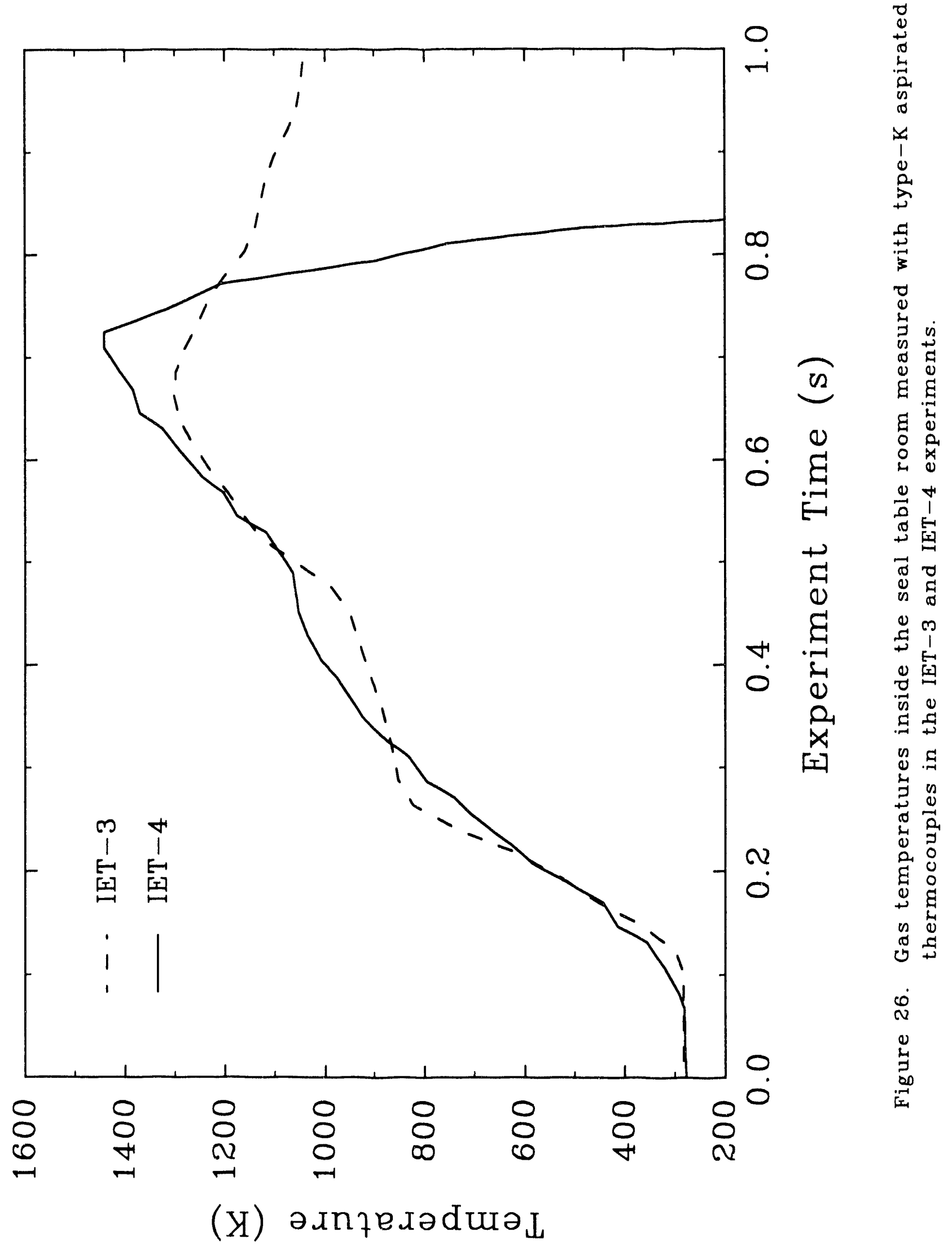




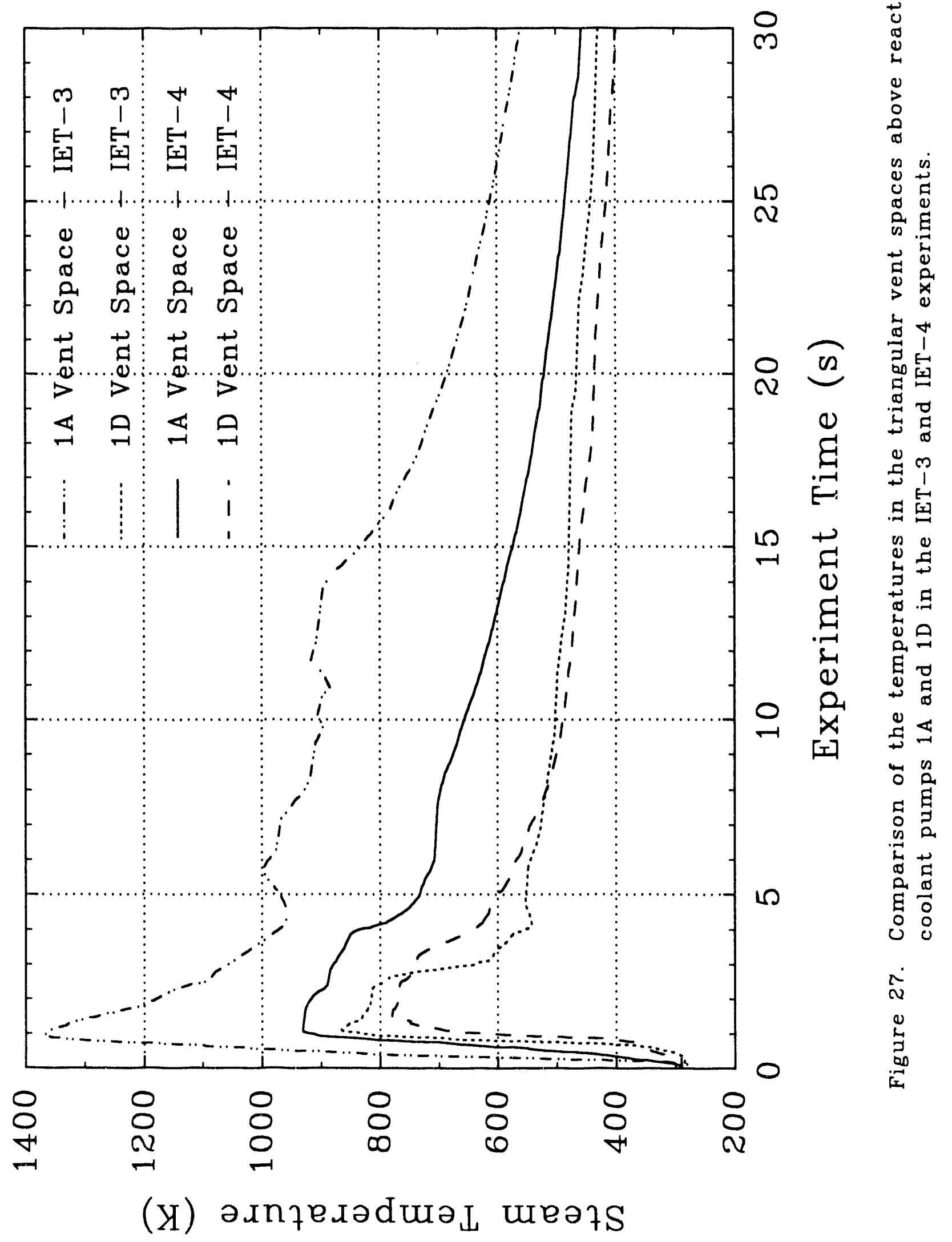




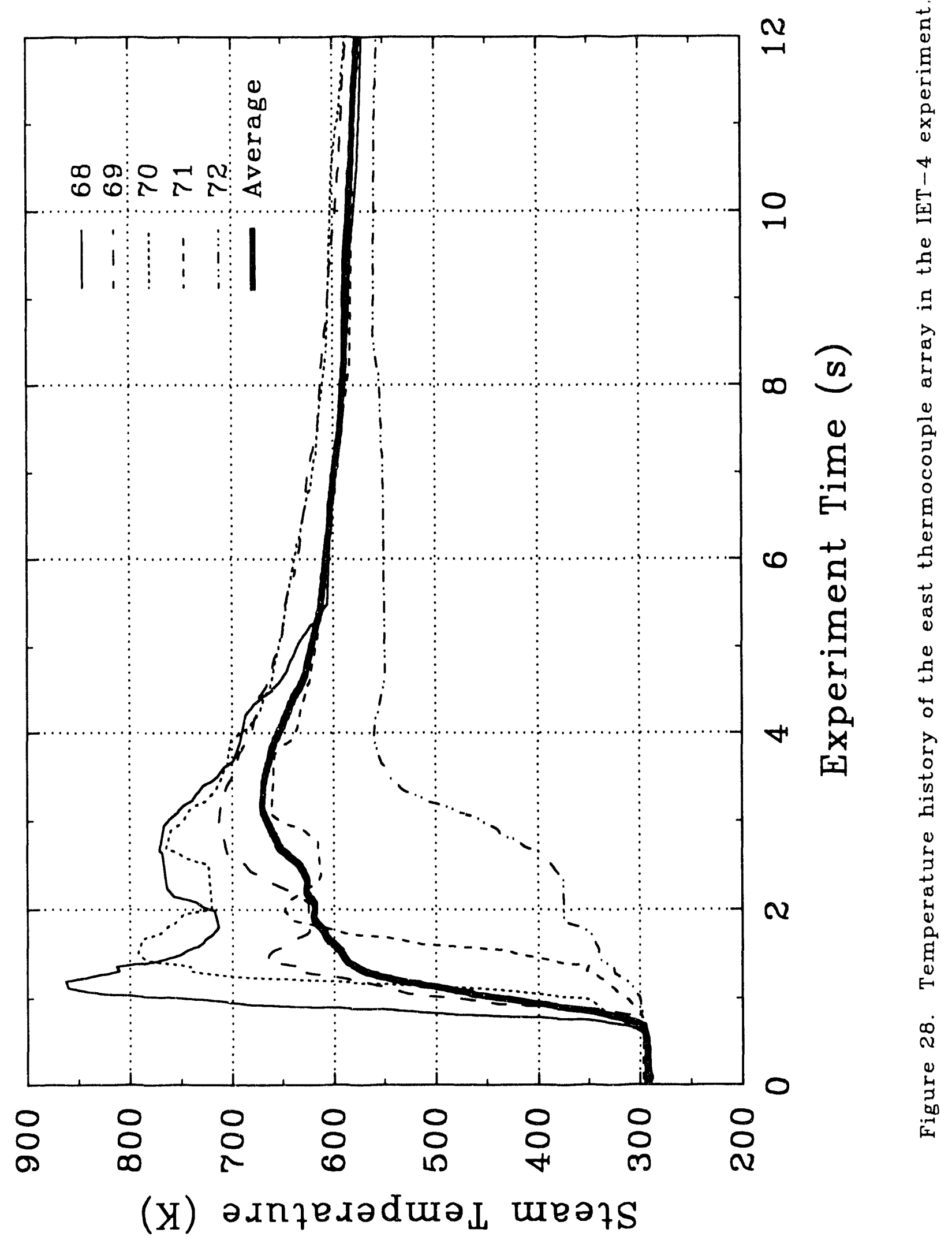




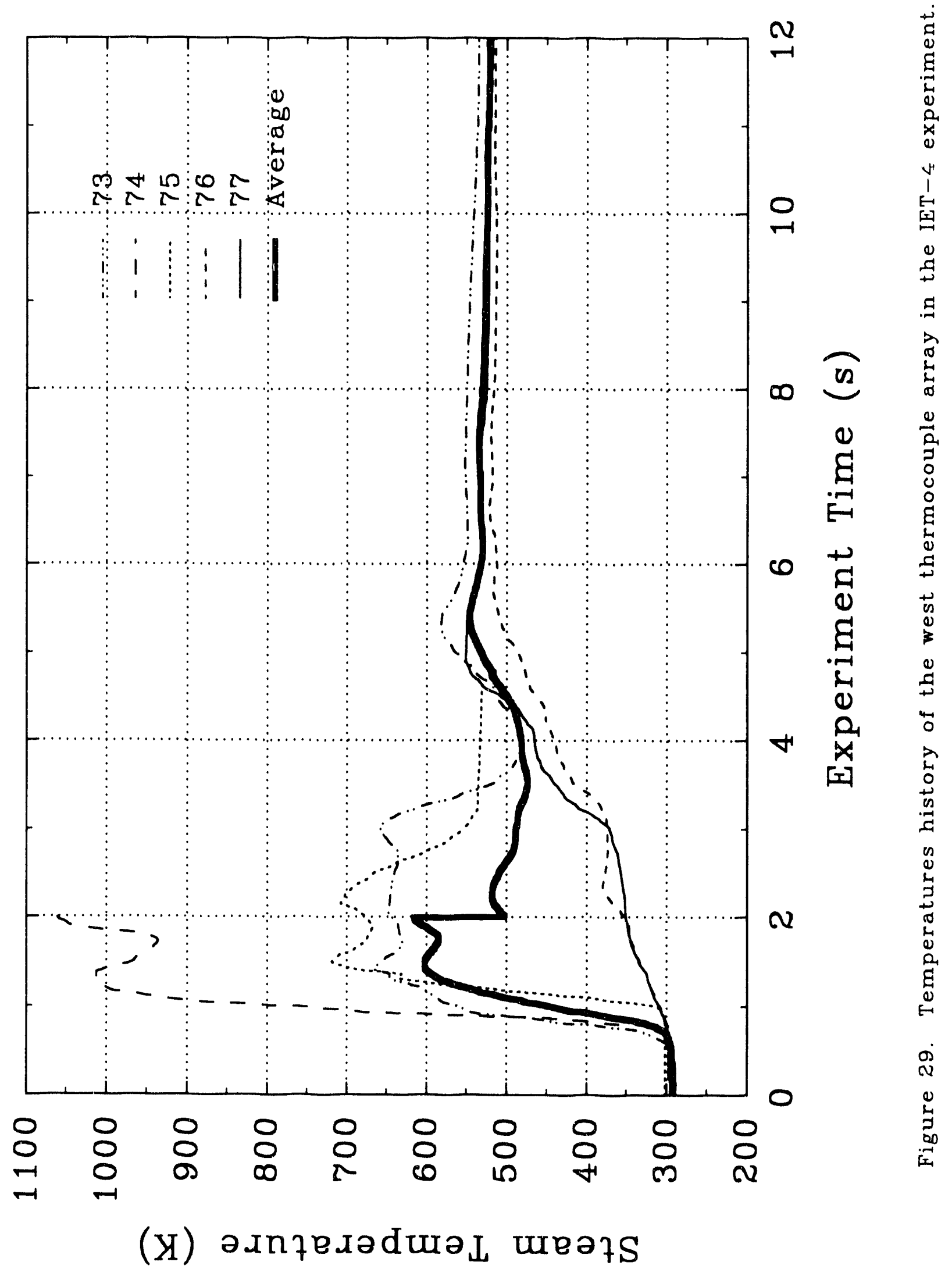




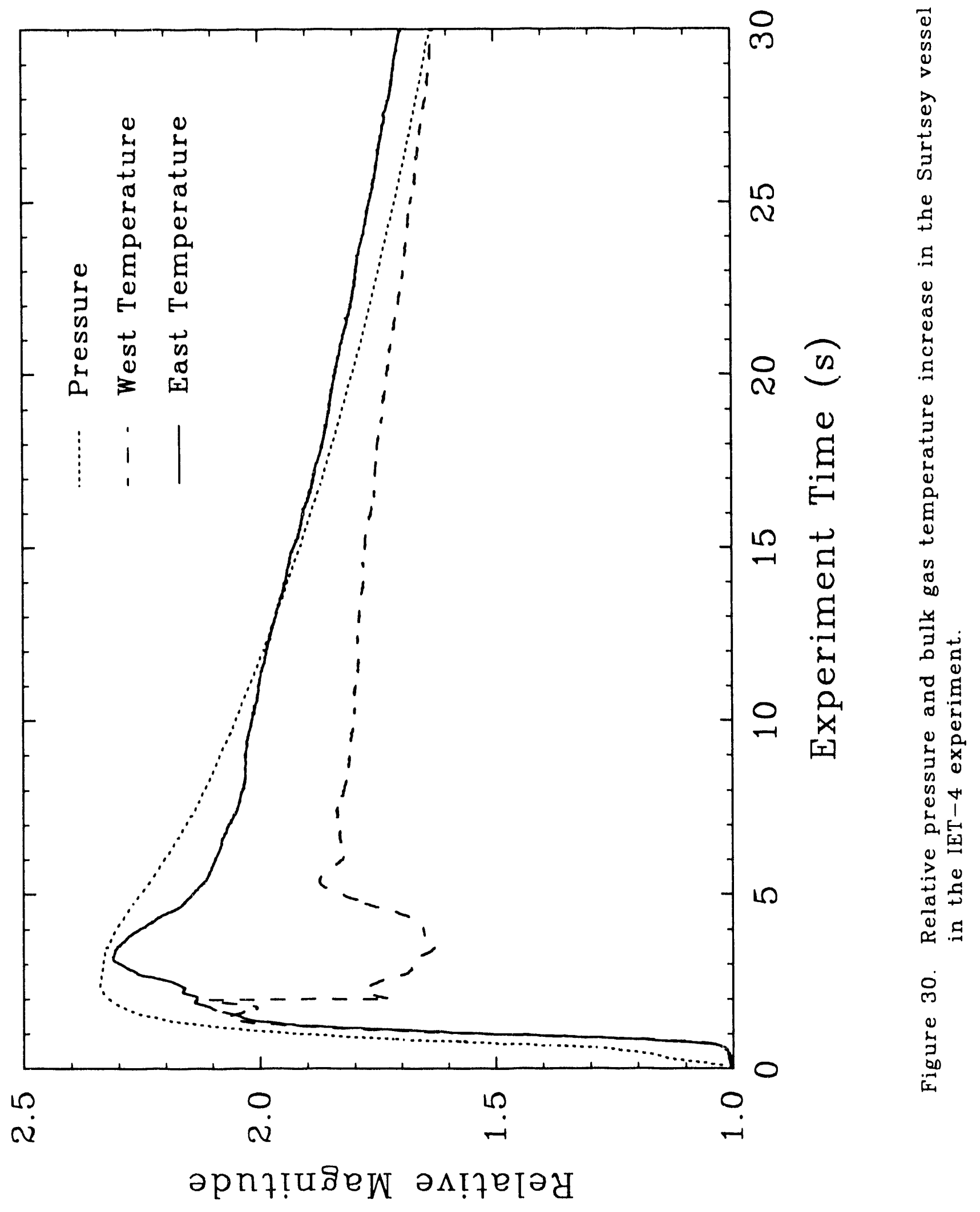




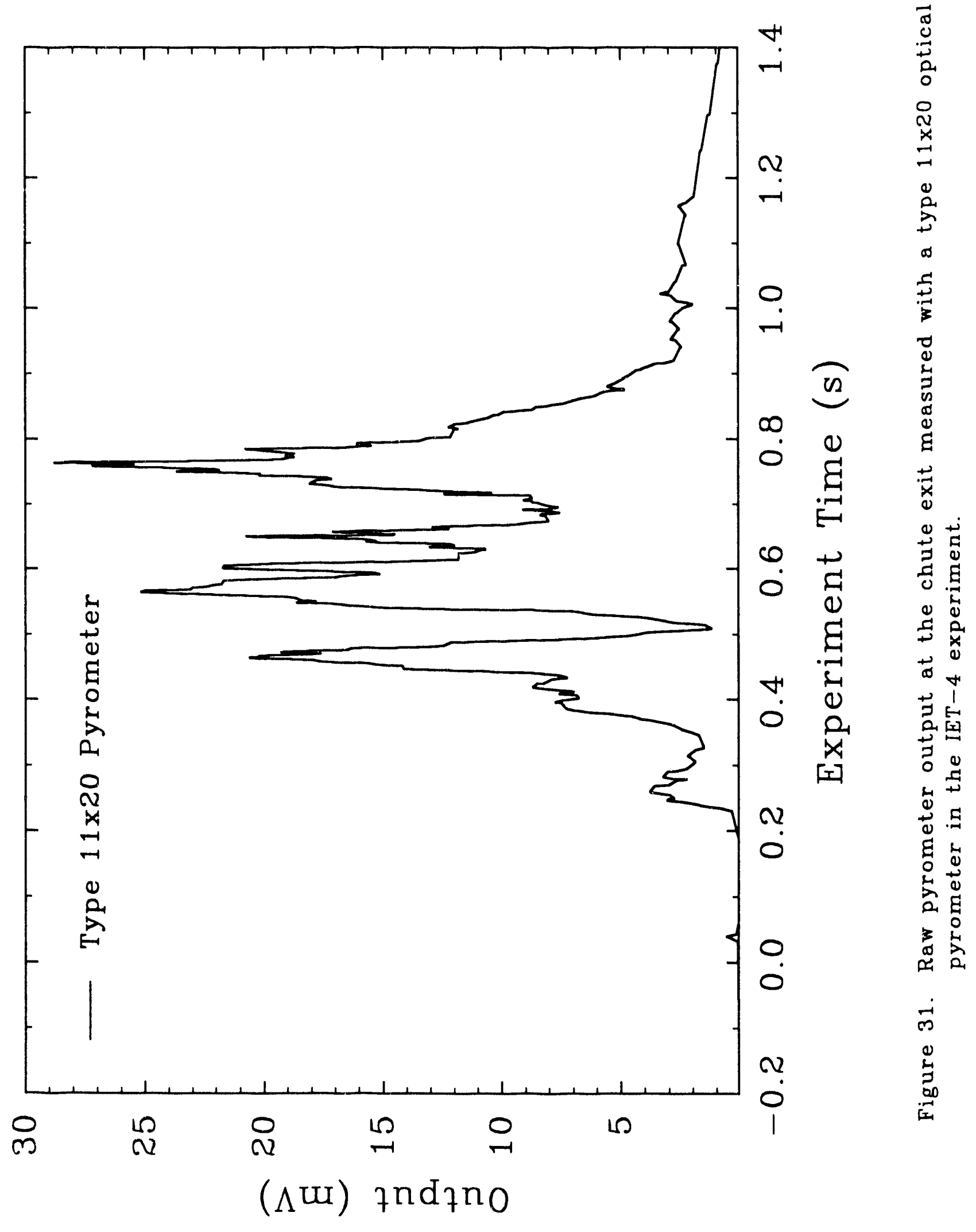




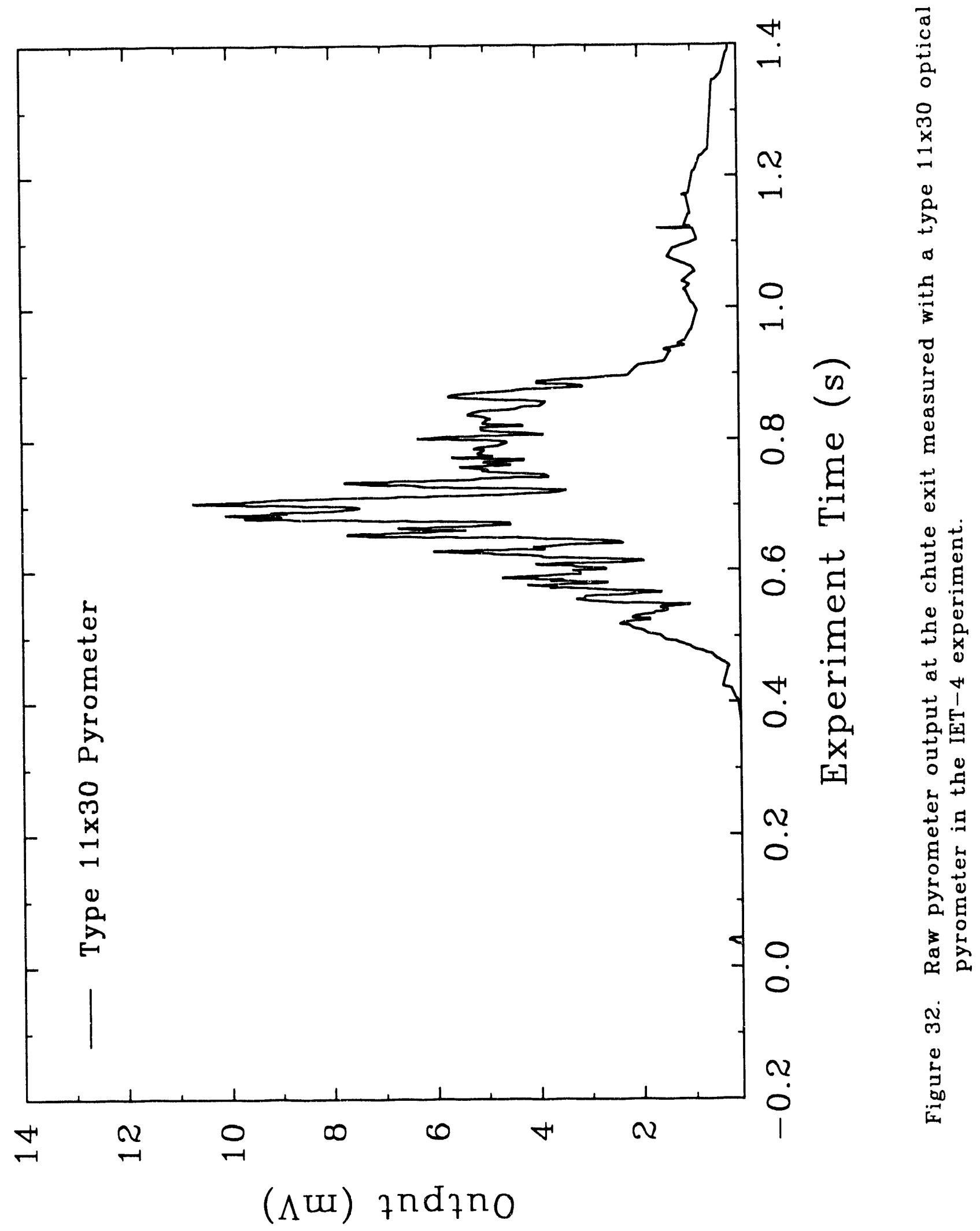




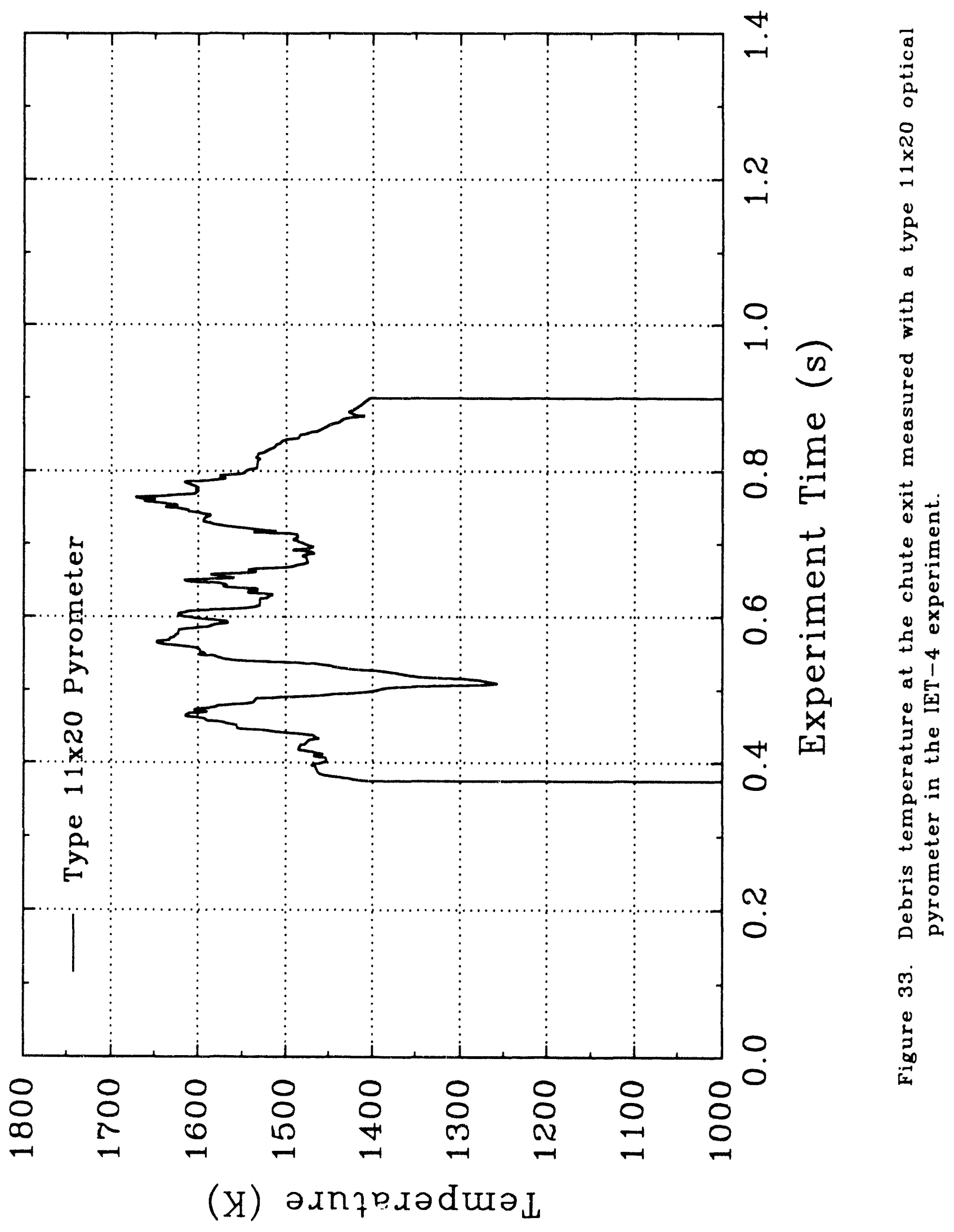




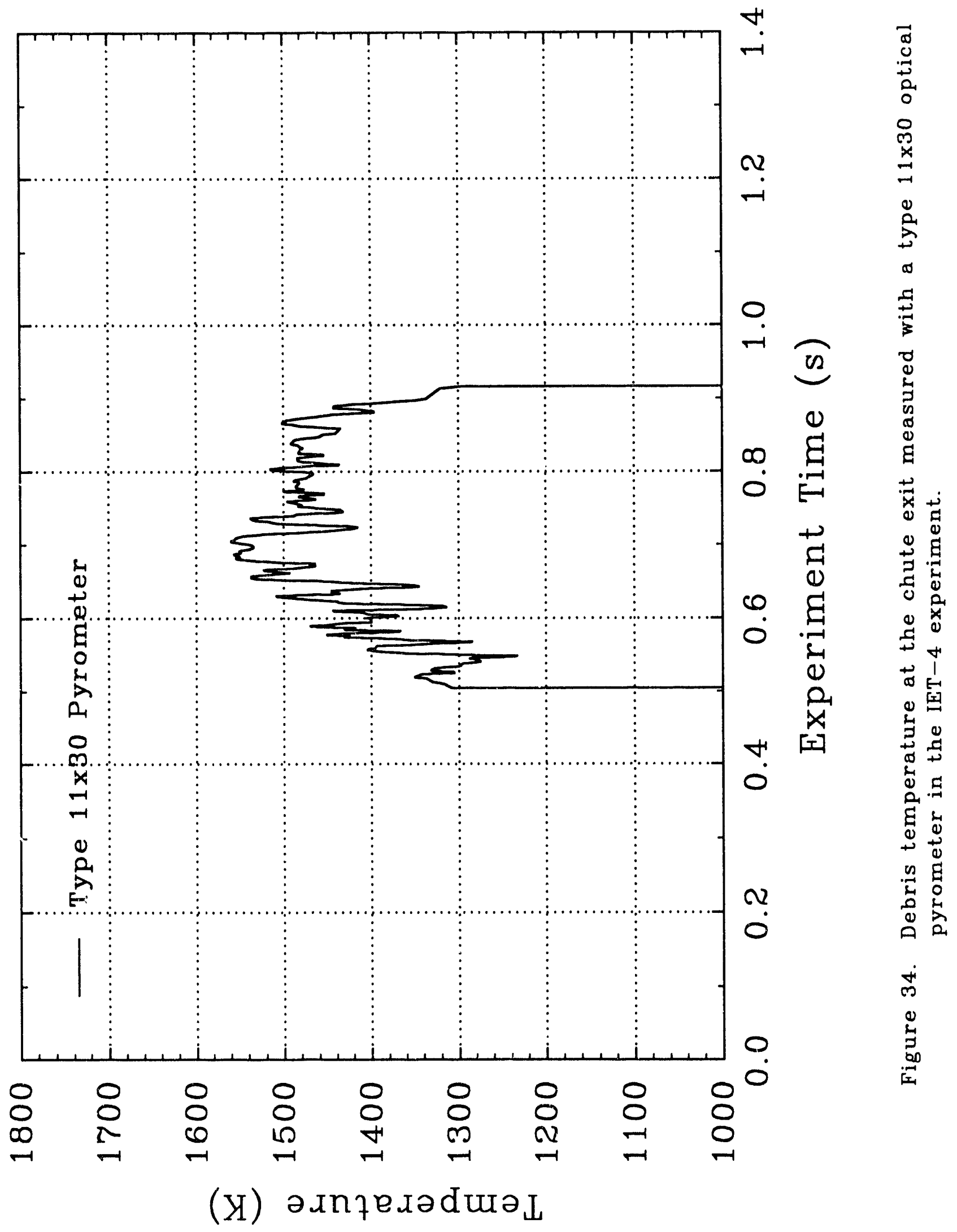




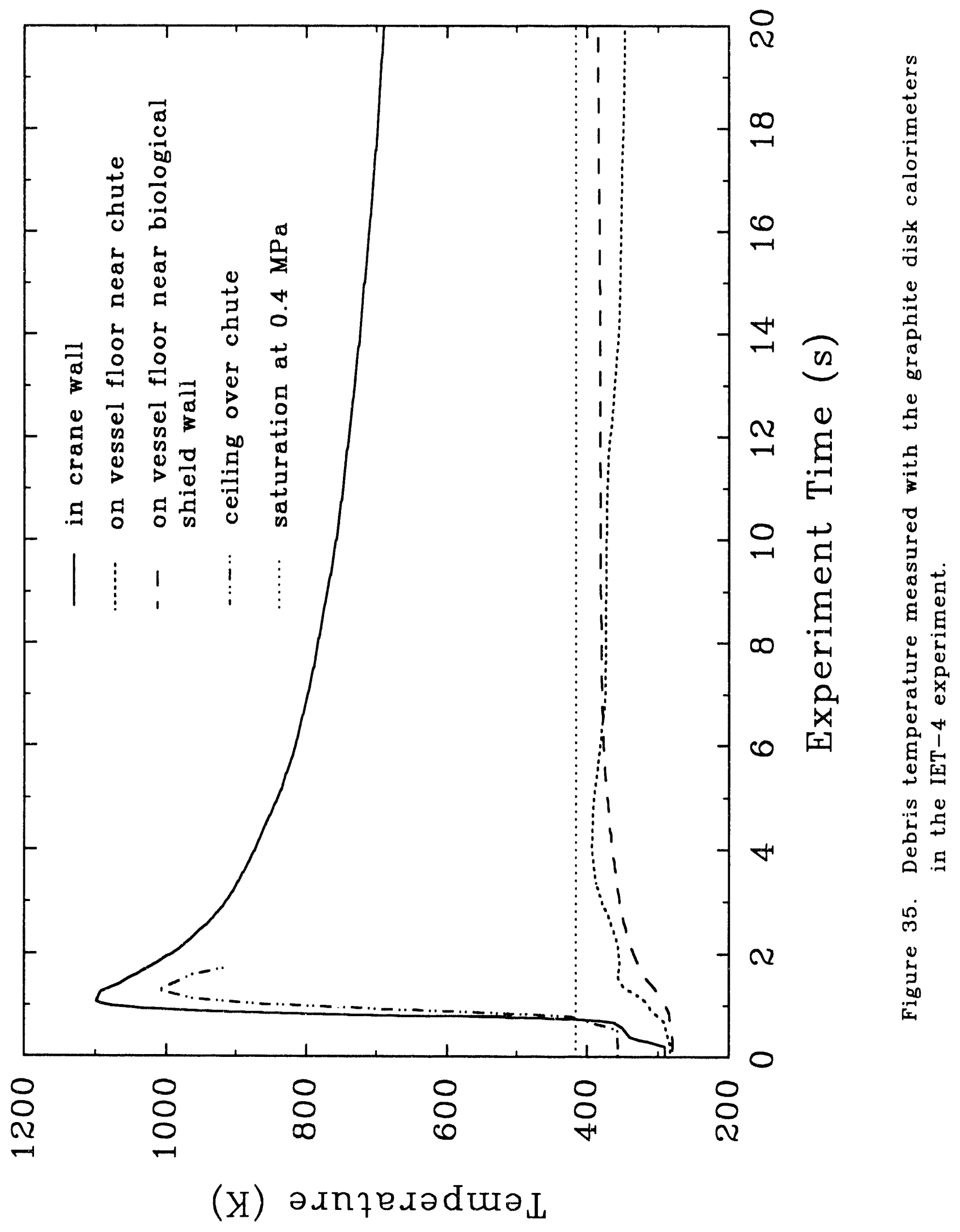




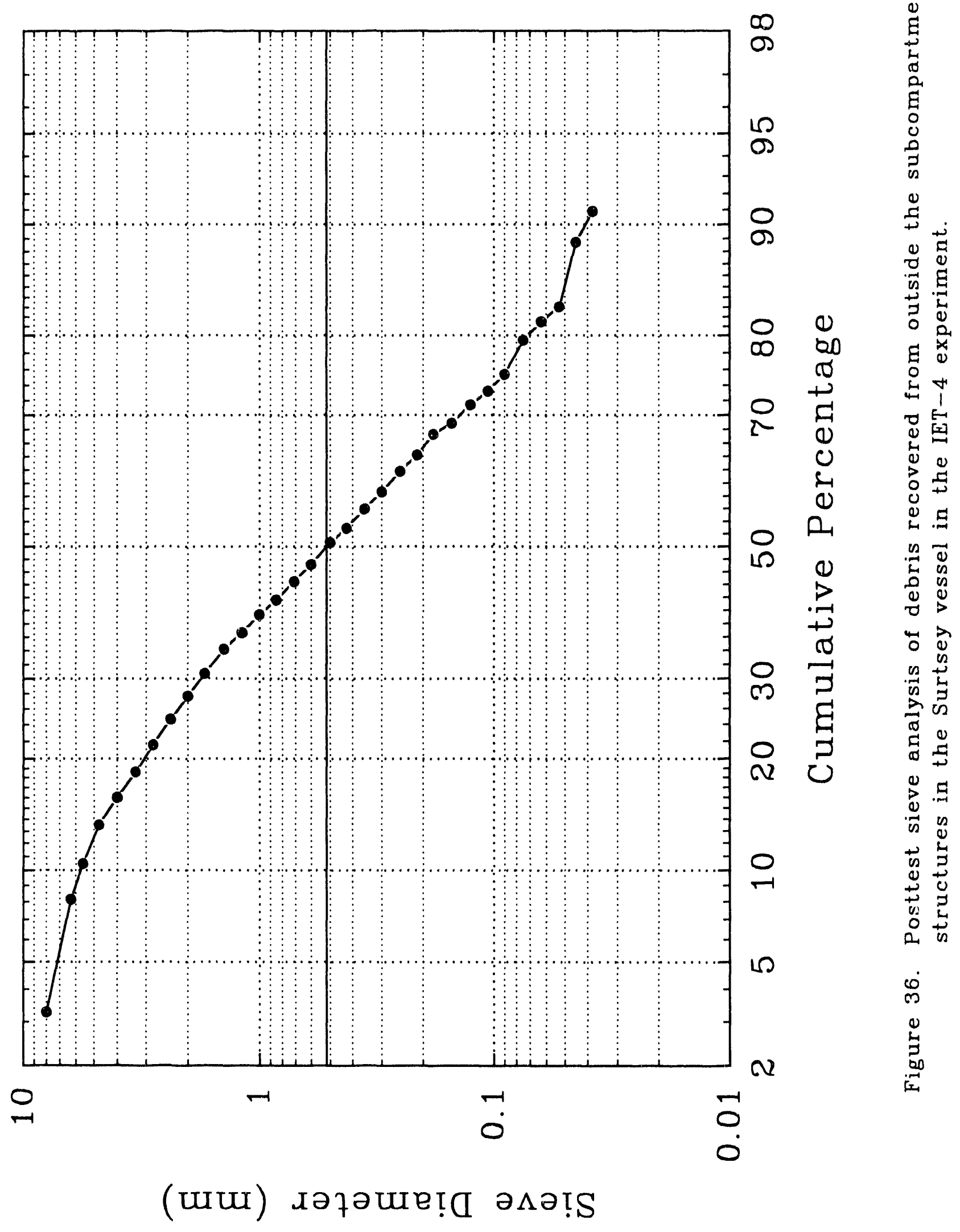




\subsection{REFERENCES}

Allen, M. D., M. Pilch, R. T. Nichols and R. O. Griffith, Oct. 1991, Experiments to Investigate the Effect of Flight Path on Direct Containment Heating (DCH) in the Surtsey Test Facility: The Limited Flight Path (LFP) Tests, NUREG/CR-5728, SAND91-1105, Sandia National Laboratories, Albuquerque, NM.

Allen, M. D., M. Pilch, R. O. Griffith and R. T. Nichols, Mar. 1992a, Experiments to Investigate the Effect of Water in the Cavity on Direct Containment Heating (DCH) in the Surtsey Test Facility - The WC-1 and WC-2 Tests, SAND91-1173, Sandia National Laboratories, Albuquerque, NM.

Allen, M. D., M. Pilch, R. O. Griffith and R. T. Nichols, Mar. 1992b, Experimental Results of Tests to Investigate the Effects of Hole Diameter Resulting from Bottom Head Failure on Direct Containment Heating (DCH) in the Surtsey Test Facility - The WC-1 and WC-3 Tests, SAND91-2153, Sandia National Laboratories, Albuquerque, NM.

Allen, M. D., M. Pilch, R. O. Griffith, D. C. Williams and R. T. Nichols, Mar. 1992c, The Third Integral Effects Test (IET-3) in the Surtsey Test Facility, SAND92-0166, Sandia National Laboratories, Albuquerque, NM.

Allen, M. D., M. Pilch, R. O. Griffith, R. T. Nichols and T. K. Blanchat, June 1992d, Experiments to Investigate the Effects of 1:10 Scale Zion Structures on Direct Containment Heating (DCH) in the Surtsey Test Facility: The IET-1 and IET-1R Tests, SAND92-0255, Sandia National Laboratories, Albuquerque, NM.

Pilch, M. M., Oct. 1991, "Adiabatic Equilibrium Models for Direct Containment Heating," SAND91-2407C, presented at the 19th Water Reactor Safety Information Meeting, Washington, D.C.

Tarbell, W. W., M. Pilch, J. W. Ross, M. S. Oliver, D. W. Gilbert and R. T. Nichols, Mar. 1991, Pressurized Melt Ejection Into Water Pools, NUREG/CR-3916, SAND84-1531, Sandia National Laboratories, Albuquerque, NM. 


\section{DISTRIBUTION:}

U. S. Nuclear Regulatory Commission (7) Office of Nuclear Regulatory Research

Attn: C. Tinkler, NLN-344

R. Lee, NLN-344

A. Reuben, NLN-344

M. Cunningham, NLS-372

F. Eltawila, NLN-344

J. Mitchell, NLS-314

B. Sheron, NLS-007

Washington, D.C. 20555

U. S. Nuclear Regulatory Commission (3)

NRC/RES

Attn: E. Beckjord, NLS-007

B. Hardin, NLS-169

T. Speis, NLS-007

Washington, D.C. 20555

U. S. Department of Energy

Office of Nuclear Safety Coordination

Attn: R. W. Barber

Washington, D.C. 20545

U. S. Department of Energy (2)

Albuquerque Operations Office

Attn: C. E. Garcia, Director

For: C. B. Quinn

R. L. Holton

P. O. Box 5400

Albuquerque, NM 87185

Los Alamos National Laboratories

Attn: M. Stevenson

P.O. Box 1663

Los Alamos, NM 87545

W. Stratton

2 Acoma Lane

Los Alamos, NM 87544

Electric Power Research Institute (2)

Attn: A. Michiels

R. Sehgal

3412 Hillview Avenue

Palo Alto, CA 94303 
R. Sherry

JAYCOR

P. O. Box 85154

San Diego, CA 92138

UCLA

Nuclear Energy Laboratory

Attn: I. Catton

405 Hilgaard Avenue

Los Angeles, CA 90024

Brookhaven National Laboratory (6)

Attn: R. A. Bari

T. Pratt

N. Tutu

$130 \mathrm{BNL}$

Upton, NY 11973

Argonne National Laboratory (4)

Attn: J. Binder

C. Johnson

L. Baker, Jr.

B. Spencer

9700 S. Cass Avenue

Argonne, IL 60439

Fauske and Associates, Inc.

Attn: R. Henry

16W070 West 83rd Street

Burr Ridge, IL 60952

Battelle Columbus Laboratory (2)

Attn: R. Denning

J. Gieseke

505 King Avenue

Columbus, $\mathrm{OH} 43201$

Department of Energy

Scientific and Tech. Info. Center

P. O. Box 62

Oak Ridge, TN 37831

University of Wisconsin

Nuclear Engineering Department

Attn: M. L. Corradini

1500 Johnson Drive

Madison, WI 53706 
EG\&G Idaho

Willow Creek Building, W-3

Attn: R. Hobbins

P. O. Box 1625

Idaho Falls, ID 83415

Battelle Pacific Northwest Laboratory

Attn: M. Freshley

P. O. Box 999

Richland, WA 99352

Professor Agustin Alonso

E.T.S. Ingenieros Industriales

Jost Gutierrez Abascal, 2

28006 Madrid

SPAIN

Jose Angel Martinez

Sub. Emplazamientos y Programas Coop.

CONSEJO DE SEGURIDAD NUCLEAR

Justo Dorado 11

28040 MADRID

SPAIN

Juan Bagues

Consejo de Seguridad Nuckan

SOR Angela de la Cruz No 3

Madrid 28056

SPAIN

Gesellschaft fur Reaktorsicherheit (GRS)

Postfach 101650

Glockengrasse 2

5000 Koeln 1

GERMANY

Technische Universitat Munchen

Attn: Professor H. Karwat

8046 Garching, Forschungagelande

Munich

GERMANY

Siegfried Hagen

Kernforschungszentrum Karlsruhe

P.O. Box 3640

D-7500 Karlsruhe 1

GERMANY 
Kernforschungszentrum Karlsruhe (2)

Attn: P. Hofmann

B. Kuczera

Postfach 3640

75 Karlsruhe

GERMANY

Klaus Trambauer

Gesellschaft Fuer Reaktorsicherheit

Forschungsgelande

D-8046 Garching

GERMANY

UKAEA (3)

Attn: D. Sweet

S. Kinnersly 203/A32

D. Williams 210/A32

Winfrith, Dorchester

Dorset DT2 8DH

UNITED KINGDOM

UKAEA Culham Laboratory

Attn: B. D. Turland E5.157

Abingdon

Oxfordshire OX14 3DB

UNITED KINGDOM

UKAEA

Reactor Development Division

Attn: T. Butland

Winfrith, Dorchester

Dorset DT2 8DH

UNITED KINGDOM

M. R. Hayns

AEA Reactor Services

B329

Harwell

Didcot

Oxfordshire OX11 ORA

UNITED KINGDOM 
Mr. F. Abbey (2)

AEA Technology

Safety and Reliability Directorate

Wigshaw Lane

Culcheth

Cheshire WA3 4NE

UNITED KINGDOM

Simon J. Board

CEGB National Power

Barnett Way

Barnwood, Gloucestershire GL4 7RS

ENGLAND

Nigel E. Buttery

Central Elect. Gen. Board, Booths Hall

Chelford Road, Knutsford

Cheshire WA16 8QG

ENGLAND

Nucleare e della Protezione Sanitaria (DISP)

Attn: Mr. G. Petrangeli

Ente Nazionnle Energie Alternative (ENEA)

Viale Regina Margherita, 125

Casella Postale M. 2358

I-00100 Roma A. D.

ITALY

G. Caropreso

Dept. for Environintl Protection \& Health

ENEA CRE Casaccia

Via Anguillarese, 301

00100 Roma Ad.

ITALY

P. Ficara

Department for Thermal Reactors

ENEA CRE Casaccia

Via Anguillarese, 301

00100 Roma Ad.

ITALY

Alan V. Jones

Thermodynamics \& Rad. Physics, TP-650

CEC Joint Research Center, Ispra

I-21020 Ispra (Varese)

ITALY 
Dr. K. J. Brinkman

Reactor Centrum Nederland

1755 ZG Petten

THE NETHERLANDS

Mr. H. Bairiot, Chief

Department LWR Fuel

Belgonucleaire

Rue de Champde Mars. 25

B-1050 Brussels

BELGIUM

Japan Atomic Energy Research Institute

Attn: K. Sato

Fukoku Seimei Bldg.

2-2-2, Uchisaiwai-cho, Chiyoda-ku, Tokyo

100

JAPAN

Japan Atomic Energy Research Institute

Severe Accident Research Laboratory

Attn: Dr. K. Soda, Head

Tokai-mura, Naka-gun, Ibaraki-ken

319-11

JAPAN

Japan Atomic Energy Research Institute

Reactivity Accident Laboratory

Attn: Toyoshi Fuketa

Tokai-Mura, Ibaraki-Ken

319-11

JAPAN

R. D. MacDonald

Atomic Energy Canada, Ltd.

Chalk River, Ontario

CANADA KOJ IJO

Atomic Energy Canada Ltd.

Attn: Vijay I. Ngth

Sheridan Park Res. Comm.

Mississauga, Ontario

CANADA L5K 1B2 
Oguz Akalin

Ontario Hydro

700 University Avenue

Toronto, Ontario

CANADA M5G 1 X6

K. N. (Kannan) Tennankore

Safety Research Division

Whiteshell Nuclear Res. Establishment

Pinawa, Manitoba

CANADA ROE $1 \mathrm{LO}$

J. Clive Wood

Safety Research Division

Whiteshell Nuclear Res. Establishment

Pinawa, Manitoba

CANADA ROE $1 \mathrm{LO}$

M. Jankowski

IAEA

Division of Nuclear Reactor Safety

Wagranesrstrasse 5

P. O. Box 100

A/1400 Vienna

AUSTRIA

Statens Karnkraftinspektion (2)

Attn: L. Hammer

W. Frid

P. O. Box 27106

S-10252 Stockholm

SWEDEN

Studvik Energiteknik AB

Attn: K. Johansson

S-611 82 Nykoping

SWEDEN

Korea Adv Energy Research Inst

Attn: Hee-Dong Kim

P. O. Box 7

Daeduk-Danji

Choong-Nam

KOREA 
Chang K. Park

Korea Atomic Energy Research Institute

Korea Advanced Energy Research Institute

P.O. Box 7, Daeduk Danji

Taejon 305-353

KOREA

Jong In Lee

Severe Accident Assessment Department

Korea Institute of Nuclear Safety

P.O. Box 16, Daeduk-Danji

Daejeon, 305-353

KOREA

POSTECH

Department of Mechanical Engineering

Attn: Moo Hwan Kim

P. O. Box 125

Kyungbuk 790-600

KOREA

Institute of Nuclear Energy Research

Attn: Yi-Bin Chen

P. O. Box 3

Lungtan

Taiwan 32500

REPUBLIC OF CHINA

Ms. C. Lecomte

CEN FAR

60-68 Av. du G. Leclerc - B.P.6

92265 Fontenay aux Roses cedex

FRANCE

Dr. A. Meyer-Heine

CEN Cadarache

13108 Saint Paul lez Durance

FRANCE

Dr. A. Tattegrain

CEN Cadarache

13108 Saint Paul lez Durance

FRANCE 
Dr. G. Hache

CEN Cadarache

13108 Saint Paul lez Durance

FRANCE

Jacques Duco

Centre d'Etudes Nucleaires (IPSN-DAS)

Commissariat a l'Energie Atomique

Boite Postale No. 6

F-92265 Fontenay-aux-Roses Cedex

FRANCE

Maurice Gomolinski

Protection and Nuclear Safety Institute

Commissariat a l'Energie Atomique

Boite Postale No. 6

F-92265 Fontenay-aux-Roses Cedex

FRANCE

Michel Livolant

Inst. de Protection et de Surete Nucl.

Commissariat a l'Energie Atomique

Boite Postale No. 6

F-92265 Fonteriay-aux-Roses Cedex

FRANCE

Jorma V. Sandberg

Department of Nuclear Safety

Finnish Center Radiation \& Nucl. Safety

P.O. Box 268

SF-00101 Helsinki

FINLAND

Lasse Mattila

Nuclear Engineering Laboratory

Technical Research Center of Finland

P.O. Box 169

SF-00181 Helsinki

FINLAND

S. Chakraborty

Swiss Federal Nucl. Safety Inspectorate

CH-5303 Wurenlingen

SWITZERLAND 
J. Peter Hosemann

Light Water Reactor Safety Program

Paul Scherrer Institute

CH-5232 Villigen PSI

SWITZERLAND

Vladimir Asmolov

I.V. Kurchatov Institute of Atomic Energy

Moscow 123182

Kurchatov Square

USSR

1810 D. W. Schaeffer

7141 Technical Library (5)

7613-2 Document Processing

for DOE-OSTI (10)

7151 Technical Publication

6321 B. D. Zak

6400 N. R. Ortiz

6403 W. A. VonRiesemann

6404 D. A. Powers

6405 D. A. Dahlgren

6412 A. L. Camp

6414 J. E. Kelly

6415 S. L. Tnompson

6418 R. K. Cole

6422 M. D. Allen (5)

6422 T. K. Blanchat (5)

6422 J. E. Brockmann

6422 M. Pilch (5)

6422 R. T. Nichols

6422 P. Guyer (10)

6423 V.. O. Reil

6429 K. E. Washington

6429 R. O. Griffith

6429 D. C. Williams

8523-2 Central Technical Files 

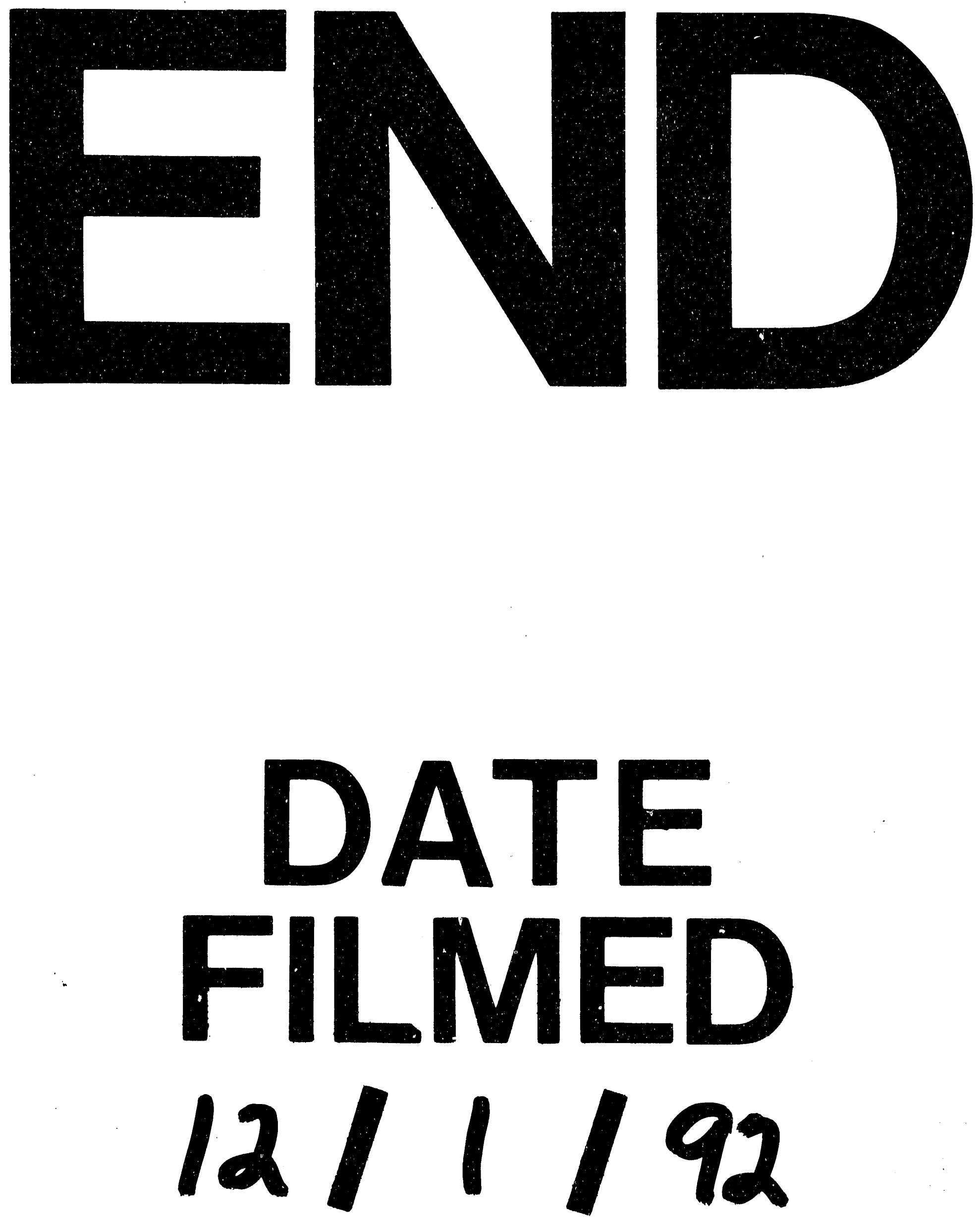
